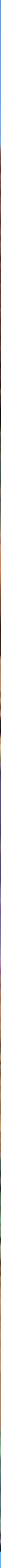

Climate adaptation and mitigation measures for nutrition co-benefits in IFAD investments in Zimbabwe

Pre-Design Mission Report

Sanne Bakker, Ilse Hennemann, Justice Nyamangara and Lesley Macheka 



\section{Climate adaptation and mitigation measures for nutrition co-benefits in IFAD investments in Zimbabwe}

Pre-Design Mission Report

Sanne Bakker ${ }^{1}$, Ilse Hennemann ${ }^{1}$, Justice Nyamangara² and Lesley Macheka²

1 Wageningen Centre for Development Innovation, Wageningen University \& Research

2 Marondera University of Agricultural Science and Technology

This research was funded by 'Adaptation for Smallholder Agriculture Programme' (ASAP) Phase 2. International Fund for Agricultural Development (IFAD)

Wageningen Centre for Development Innovation

Wageningen, June 2021

Report WCDI-21-162 
S. Bakker, I. Hennemann, J. Nyamangara, L. Macheka, 2021. Climate adaptation and mitigation measures for nutrition co-benefits in IFAD investments in Zimbabwe; Pre-Design Mission Report. Wageningen Centre for Development Innovation, Wageningen University \& Research. Report WCDI-21-162. Wageningen.

Keywords: Zimbabwe, Climate adaptation, Climate Mitigation, Nutrition, IFAD investments.

This report can be downloaded for free at https://doi.org/10.18174/547740 or at www.wur.eu/cdi (under publications).

(C) 2021 Wageningen Centre for Development Innovation, part of the Stichting Wageningen Research. P.O. Box 88, 6700 AB Wageningen, The Netherlands. T + 31 (0)317 4868 00, E info.cdi@wur.nl, www.wur.eu/cdi.

\section{(cc) BY-NC}

The Wageningen Centre for Development Innovation uses a Creative Commons Attribution 4.0 (Netherlands) licence for its reports.

The user may copy, distribute and transmit the work and create derivative works. Third-party material that has been used in the work and to which intellectual property rights apply may not be used without prior permission of the third party concerned. The user must specify the name as stated by the author or licence holder of the work, but not in such a way as to give the impression that the work of the user or the way in which the work has been used are being endorsed. The user may not use this work for commercial purposes.

The Wageningen Centre for Development Innovation accepts no liability for any damage arising from the use of the results of this research or the application of the recommendations.

Report WCDI-21-162

Photo cover: David Brazier, Flickr 


\section{Contents}

1.1 Background 9

$\begin{array}{ll}1.2 & \text { Assignment objectives and scope } \\ 1.3 & 10\end{array}$

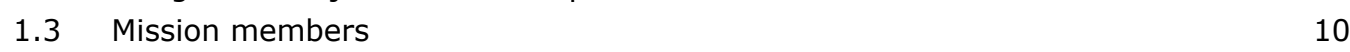

$\begin{array}{lll}1.4 & \text { Methodology } & 11\end{array}$

$\begin{array}{lll}1.5 & \text { Analysis using a food systems approach } & 11\end{array}$

3.1 Impact of climate on food systems $\quad 16$

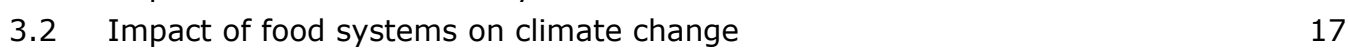

$\begin{array}{lll}3.3 & \text { Impact of nutrition on climate change } & 17\end{array}$

$\begin{array}{ll}3.4 & \text { Impact of climate change on other drivers of nutrition } \\ \end{array}$

$4 \quad$ Present Nutrition Situation in Zimbabwe $r$

4.1 Trends of malnutrition $\quad 19$

4.2 Main determinants of malnutrition in Zimbabwe $\quad 20$

$\begin{array}{ll}4.2 .1 \text { Food security } & 20\end{array}$

$\begin{array}{ll}4.2 .2 \text { Food consumption patterns } & 20\end{array}$

4.2.3 Consumption of specific foods $\quad 22$

4.2.4 Care 24

4.2.5 Adolescent nutrition 26

$\begin{array}{ll}4.2 .6 \text { Gender } & 26\end{array}$

4.2.7 WASH 27

4.2.8 Vulnerability to malnutrition (by area and household type) 28

$\begin{array}{lll}4.3 & \text { Policy arena nutrition } & 29\end{array}$

$5 \quad$ Present Climate Situation in Zimbabwe $\quad 31$

5.1 Climate trends and projections $\quad 31$

5.2 Climate change impacts 31
5.2.1 Agriculture
5.2.2 Crop suitability $\quad 32$
5.2.3 Livestock $\quad 32$
5.2.4 Post-harvest food loss 33
5.3 Climate Vulnerable Groups $\quad 33$
$\begin{array}{lll}5.4 & \text { Spatial vulnerability } & 35\end{array}$
$\begin{array}{lll}5.5 & \text { Early Warning Systems } & 38\end{array}$
$\begin{array}{lll}5.6 & \text { Policy Arena Climate Change } & 40\end{array}$

6.1 Improved income $\quad 42$

6.2 Investment in resilient value chains with nutrition value 43

$\begin{array}{lll}6.3 & \text { Strengthening value chain linkages } & 48\end{array}$

$\begin{array}{lll}6.4 \text { Women's empowerment } & 50\end{array}$ 
6.5 Youth inclusion in agricultural value chain development 52

6.6 Capacity on nutrition and climate of agricultural extension workers 54

$\begin{array}{lll}6.7 & \text { Reduce post-harvest losses } & 56\end{array}$

$7 \quad$ Further recommendations \& considerations $\quad \mathbf{5 7}$

$\begin{array}{lll}7.1 & \text { Selection of intervention areas } & 57\end{array}$

$\begin{array}{lll}7.2 & \text { Implementation arrangements } & 60\end{array}$

Appendix $1 \quad$ Conceptual linkages between climate and nutrition by IFPRI (2015) 62

$\begin{array}{lll}\text { Appendix } 2 & \text { Food Systems Framework } & 63\end{array}$

$\begin{array}{llr}\text { Appendix } 3 & \text { Value chain overview } & 64\end{array}$

$\begin{array}{lll}\text { Appendix } 4 \quad \text { List of interviewees } & 74\end{array}$

$\begin{array}{lll}\text { Appendix } 5 & \text { Interview guide } & 75\end{array}$

$\begin{array}{lll}\text { Appendix } 6 & \text { Terms of Reference - Assignment } & 77\end{array}$

$\begin{array}{lll}\text { Appendix } 7 & \text { Analysis of stakeholders and nutrition actions relevant for SACP } & 80\end{array}$ 


\section{Acknowledgements}

We would like to express our appreciation to Dr George Kembo, Hilton Mbozi, Sakile Kudita, Dr Conrad Zawe, Delilah Takawira, Mr Bernard Mache, Dr Martin Moyo and his entire ICRISAT team, Dr. Sandra Bhatasara, Mr Clophas Ncube, Mr Washington Zhakata all of them making themselves available on short notice to share their experiences and views and answer our questions.

A special thanks to Janaa Keitaanranta \& Joylyn Ndoro and to the rest of the IFAD design team Sauli Hurri, Paxina Chileshe who supported us in the shaping of this assignment and shared their experiences and insight with our team.

With gratitude we thank the IFAD team, Ilaria Bianchi and Joyce Njoro in Rome, who despite their confinement to their homes helped us with their valuable contributions and the overall coordination of this mission. 


\section{List of abbreviations and acronyms}

\begin{tabular}{|c|c|}
\hline$A C$ & Adaptive Capacity \\
\hline ASAP & Adaptation for Smallholder Agriculture Programme \\
\hline CCAFs & CGIAR Research Program on Climate Change, Agriculture and Food Security \\
\hline $\mathrm{CCF}$ & Climate Finance Facility \\
\hline CGIAR & Consultative Group on International Agricultural Research \\
\hline CIAT & International Center for Tropical Agriculture \\
\hline CRA & Climate Risk Analysis \\
\hline CSA & Climate Smart (resilient) Agriculture \\
\hline COSOP & Country Strategic Opportunities Programme \\
\hline EWS & Early Warning Systems \\
\hline GHGs & Greenhouse Gas Emissions \\
\hline FAO & Food and Agriculture Organization \\
\hline FLW & Food Loss and Waste \\
\hline FNC & Food and Nutrition Council \\
\hline FNSC & Food and Nutrition Security Committee \\
\hline GALS & Gender Action Learning System \\
\hline GDP & Gross domestic product \\
\hline GHG & Greenhouse gasses \\
\hline GNR & Global Nutrition Report \\
\hline HLPE & High Level Panel of Experts on Food Security and Nutrition \\
\hline ICRISAT & International Crops Research Institute for the Semi-Arid Tropics \\
\hline IDBZ & Infrastructure Development Bank of Zimbabwe \\
\hline IFAD & International Fund for Agricultural Development \\
\hline IFPRI & International Food Policy Research Institute \\
\hline IKS & Indigenous Knowledge Systems \\
\hline IYCF & Infant and young child feeding \\
\hline LBW & Low birth weight \\
\hline LFSP & Zimbabwe Livelihoods Food Security Programme \\
\hline LMIC & Low and middle income countries \\
\hline MAD & Minimum acceptable diet \\
\hline MDD & Minimum dietary diversity \\
\hline MMF & Minimum meal frequency \\
\hline $\mathrm{MoHCC}$ & Ministry of Health and Child Care \\
\hline MSD & Meteorological Services Department \\
\hline MSP & Multi-Stakeholder Partnerships \\
\hline MUAST & Marondera University of Agricultural Sciences \& Technology \\
\hline NAPF & National Agriculture Policy Framework (Zimbabwe) \\
\hline NCD & Non-communicable disease \\
\hline NDC & Nationally Determined Contribution (to the UNFCCC) \\
\hline RCP & Representative Concentration Pathways \\
\hline SSA & Sub-Saharan Africa \\
\hline SHF & Smallholder farmer \\
\hline SIRP & Smallholder Irrigation Revitalization Programme \\
\hline UNFCCC & United Nations Framework Convention on Climate Change \\
\hline UNICEF & United Nations Children's Fund \\
\hline UNDRR & UN Office for Disaster Risk Reduction \\
\hline VC & Value chain \\
\hline WCDI & $\begin{array}{l}\text { Wageningen Centre for Development Innovation, Wageningen University \& } \\
\text { Research }\end{array}$ \\
\hline WFP & World Food Programme \\
\hline WHO & World Health Organization \\
\hline WRA & Women of reproductive age \\
\hline WUR & Wageningen University \& Research \\
\hline ZimVac & Zimbabwe Vulnerability Assessment Committee \\
\hline
\end{tabular}




\section{Introduction}

\section{$1.1 \quad$ Background}

IFAD designed a project for the adoption of climate adaptation measures which increase nutrition cobenefits for smallholder farmers and their families. The project is titled 'Climate change and nutrition in value chain development' and it is funded under ASAP 2 (Adaptation for Smallholder Agriculture Programme - Phase II). The ASAP is IFAD's flagship programme for channelling climate and environmental finance to smallholder farmers and is incorporated into IFAD's regular investment processes, benefitting from rigorous quality control and supervision systems. The project aims to develop a tried and proven methodology and approach to support project designs/mid-term reviews and strengthen the capacity of IFAD teams to conduct comprehensive and integrated assessments at project design that allow for the identification of adaptation and mitigation actions, while also reducing nutrition risks of food value chain investments.

In order to implement most of the activities of the above initiative, the provision of high quality technical support has been requested by IFAD from Wageningen Centre for Development Innovation (WCDI). WCDI support will allow IFAD to develop an integrated approach for designing climate-smart and nutrition-sensitive value chains, hereby contributing to the operationalisation of IFAD's transformational framework for mainstreaming themes and to reinforce the capacities of local actors.

This technical support provided by WCDI includes the three pre-design studies for three projects, in three IFAD supported countries, namely:

- Project on Regeneration of Livelihoods Landscapes (P-ROLL) in Lesotho

- Climate-Smart Smallholder Value Chain Project (SVCP) in Vietnam

- Smallholder Agriculture Cluster Project (SACP) in Zimbabwe

This reports describes the findings and recommendations of the pre-design study for SACP in Zimbabwe. Zimbabwe has been a member of IFAD since its independence in 1980. IFAD's financial support to the country ceased in 2006, as a result of the non-payment of its arrears, and three ongoing projects were also terminated. IFAD has remained committed to resuming its development programme with Zimbabwe and support the Government in reducing poverty. During the recent years, IFAD has provided small grants to the country to fund a range of projects, including the Smallholder Agricultural Support Project (US\$500,000) and two Small Livestock Improvement Projects (US\$400,000).

Following an official request from the Government of Zimbabwe in 2015, Zimbabwe's debt to IFAD was rescheduled, a new Country Strategic Note was developed. The Government of Zimbabwe and IFAD agreed that Smallholder Irrigation Revitalization Programme (SIRP) would be the first IFAD supported investment project, marking its re-engagement in Zimbabwe.

The SIRP, is currently the only active IFAD programme in Zimbabwe, and aims to revitalise 6,100 hectares in 152 existing smallholder irrigation schemes in the semi-arid zones in four provinces: Manicaland, Masvingo, Matabeleland South and Midlands and to target over 27,700 poor rural households,. The programme covers some 46 per cent of the country's estimated total irrigationequipped area of about 13,000 hectares. It aims at improving productivity and climate-resilient crop production under both rain-fed and irrigated conditions, through diversification of crops and increased adoption of improved varieties, combined with climate-smart agricultural practices and, most importantly, enhanced access to markets. In addition, the programme wants to improve the management of natural resources at the village level, including soil and water conservation in the catchment areas adjacent to the irrigation schemes. SIRP is designed to help drought-hit smallholder farmers to improve access to markets and fertilisers and adopt climate-smart agricultural practices to 
boost productivity so they can generate sufficient revenues to defray the costs of operating and maintaining irrigation schemes as well as achieve nutrition and food security.

IFAD's strategy in Zimbabwe, supports the implementation of the National Agriculture Policy Framework (NAPF) 2018-2030. ${ }^{1}$ With its long-term support to Zimbabwe's rural agriculture, IFAD is a trusted development partner for the Government. It is also considered to be a neutral broker between government and other stakeholders on agriculture and rural development policies. Moreover, IFAD has a comparative advantage in supporting Zimbabwe's agriculture sector, which stems from its extensive experience and support for: a) commercialisation of smallholder agriculture; b) increasing production and productivity; c) agro-processing and facilitating farmers' access to markets; and d) developing sustainably inclusive value chains, while contributing to improved nutrition. IFAD's current portfolio in Zimbabwe consists of the SIRP programme implemented in four provinces.

\subsection{Assignment objectives and scope}

The objective of the pre-design mission has been formulated as:

To conduct a pre-design study mission for Zimbabwe with the aim to explore opportunities for climate adaptation and mitigation and nutrition actions for IFAD investments in Zimbabwe (forthcoming: SACP).

\section{Specific objectives}

Specific objectives regarding the first part (20 April - 2 May 2020) of the pre-design study include:

- Based upon the lessoned learned from literature review, to explore which of the lessons learned can be applied in the Zimbabwe context;

- To consult with selected key stakeholders to describe the present climate adaption and mitigation and nutrition landscape, including targeting vulnerable groups and stakeholder involvement;

- To formulate appropriate pathways and suitable, sustainable, significant actions that effectively integrate climate mitigation and adaptation measures to maximise nutrition in IFAD's investments (including strategies, processes and/or methodologies if appropriate) and capable of enriching IFAD's project designs with climate-nutrition linkages;

- To suggest feasible and concrete actions that can then be incorporated into the full design of SACP and flesh it out further.

Detailed Terms of Reference can be found in Appendix 6.

\subsection{Mission members}

The pre-design mission team was comprised of the following members:

- Ilse Hennemann, Advisor Environmental Governance \& Climate Change, WCDI

- Sanne Bakker, Advisor Food and Nutrition Security, WCDI

- Justice Nyamangara, Independent Consultant Climate and Agriculture

- Lesley Macheka, Independent Consultant Food and Nutrition

The following IFAD staff members in close collaboration with the ECG Division (Ilaria Bianchi, Joyce Njoro) and the Zimbabwe Country team (Janaa Keitaanranta, Joylyn Ndoro).

1 IFAD: Zimbabwe: Country Strategic Opportunities Programme: 2020-2026, p. 7. 


\title{
1.4 Methodology
}

The following methodologies were used:

- Review of secondary data sources provided by the IFAD Zimbabwe team and ECG Division, as well sources available online. Secondary sources included in this study are listed in the footnotes of this report.

- Interviews with key informants (see annex for list of interviewees and interview guide). The semistructured interview guide was developed based on the IFAD guidance materials on the mainstreaming themes (Environment and Climate, Gender, Nutrition and Youth), the SACP concept note dated 28 April and the draft COSOP for Zimbabwe.

- E-consultation through Zoom and Skype.

- Analysis using a food systems approach (see next section).

\subsection{Analysis using a food systems approach}

How to provide sufficient, affordable, safe and quality nutritious food and simultaneously ensure enhanced livelihoods, a climate-resilient system in harmony with and not at the expense of the environment, biodiversity and animal welfare? Answering that question is not possible by using a supply or value chain approach alone. Therefore, the predesign mission used an adapted food systems approach to analyse the bidirectional relationships between climate change and nutrition along the entire food value chain.

\begin{abstract}
What are food systems?
Food systems are the sum of actors and interactions along the food value chain-from input supply and production of crops, livestock, fish, and other agricultural commodities to transportation, processing, retailing, wholesaling, and preparation of foods, to consumption and disposal. Food systems also include the enabling policy environments and cultural norms surrounding food. Food systems provide basic sustenance in terms of meeting populations' minimum caloric needs and affect nutrition positively or negatively, through crop health, dietary diversity and impacts on human health and the environment. Food systems also provide livelihoods for a sizable share of the global population, through agricultural labour and non-farm jobs in other segments of the food value chain. The income garnered from these jobs can be used to purchase a wide array of healthy foods, send children to school, purchase health services, medications and more. At the macro level, food systems power local and national economies, shaped in part by governance, trade, and investment at the global level.

Ideal food systems would be nutrition, health, and safety-driven, productive and efficient (and thus able to deliver affordable food), environmentally sustainable, climate-smart and inclusive. But to realise this vision, continued investments must be made in agricultural research and development and technological innovations, paving the way for programmes and policies that are based on sound evidence.
\end{abstract}

Source: IFPRI, 2020

To sum up, a food system gathers all the elements (environment, people, inputs, processes, infrastructures, institutions, etc.) and activities that relate to the production, processing, distribution, preparation and consumption of food, and the outputs of these activities, including socio-economic and environmental outcomes.

A food systems approach is a useful interdisciplinary conceptual framework for research, programmes and policies aimed at sustainable solutions for the sufficient supply of healthy food. The approach helps to analyse the relationships between the different parts of the food system and the outcomes of activities within the system in nutrition and health, socio-economic and environmental/climate terms ${ }^{2}$.

2 Siemen van Berkum, Just Dengerink and Ruerd Ruben, 2018. The food systems approach: sustainable solutions for a sufficient supply of healthy food. Wageningen, Wageningen Economic Research, Memorandum 2018-064. 32 pp.; 9 fig.; 0 tab.; 39 ref. 
Climate is a driver and an outcome of the food system. Nutrition is an outcome of the food system, and dietary patterns determine the food production systems can be found in the food system.

The mission team used the framework ${ }^{3}$ developed by the High Level Panel of Experts of Food Security and Nutrition. This specific framework was selected due to it additions to previous food system frameworks; it helps to understand how consumers interact with the food system, by adding the component of a food environment. The framework was used (i) to map the food system in Zimbabwe, including important drivers and (ii) to identify where the SACP project can support shaping the food system, to contribute to improved nutrition and ensure that food is produced, distributed and consumed in a sustainable and inclusive manner - and is resilient to climate change. Key information related to the drivers of the food system have been summarised in the visual of the conceptual framework. The team expanded the original framework with more details on the climate vulnerability and social inclusion context, as the SACP project aims to transform these contexts, which in turn, will affect the food value chain and its results.

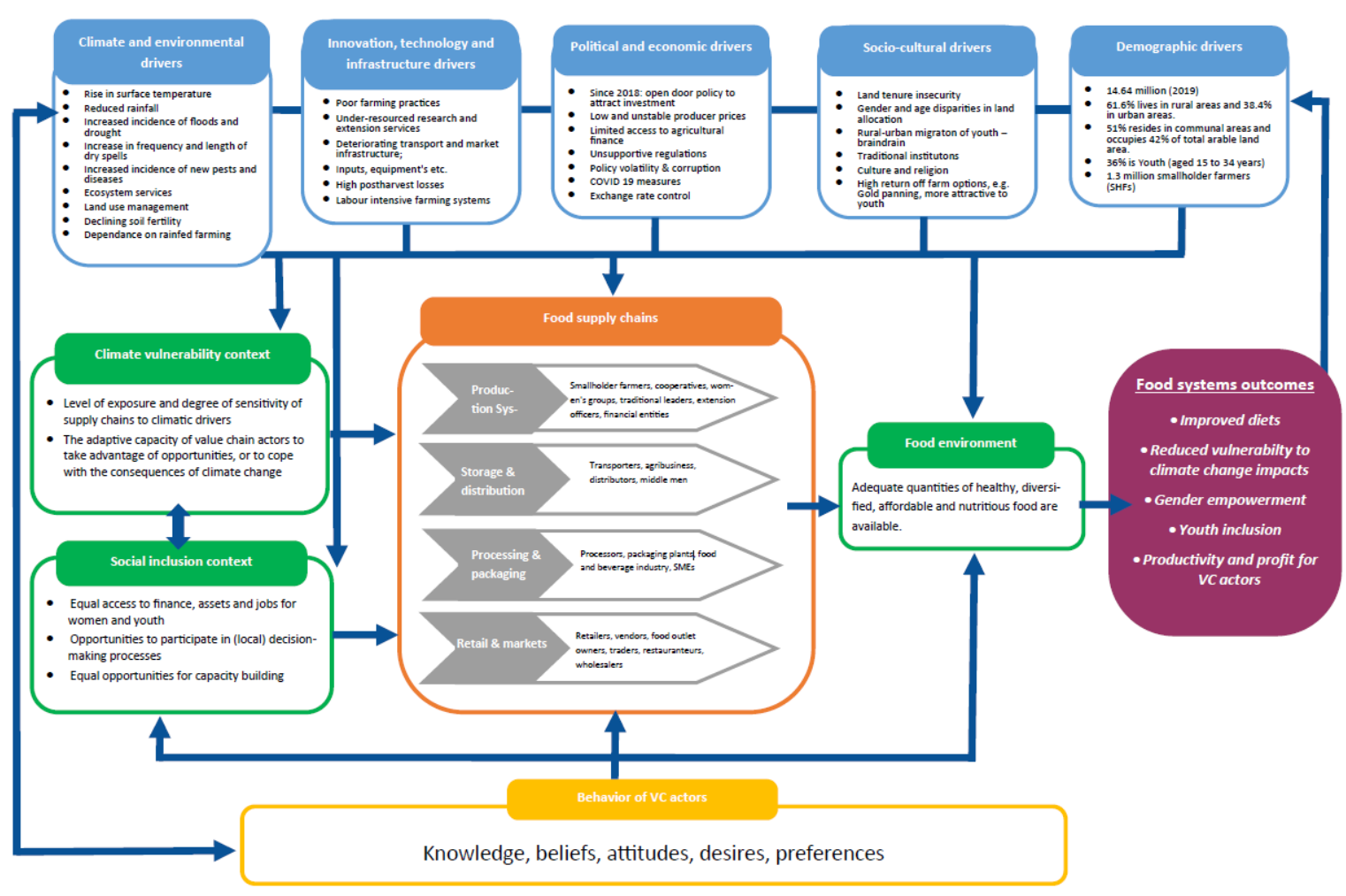

Figure 1 Food Systems Framework (and in Annex 8.2) - adapted from conceptual framework of food systems developed by the High Level Panel of Experts on Food Security and Nutrition (HLPE, 2017).

3 HLPE. 2017. Nutrition and food systems. A report by the High Level Panel of Experts on Food Security and Nutrition of the Committee on World Food Security, Rome. 


\section{COVID-19 Implications}

The Covid-19 pandemic has impacted us on a global scale. How extreme the ultimate consequences will be is only gradually unfolding. Understanding of the perceived effects and implication of local food systems and effects on nutrition can help prioritise potential mitigation measures to respond and recover from the Covid-19 related shocks.

Wageningen University \& Research ${ }^{4}$ has undertaken a rapid appraisal to understand vulnerabilities of local food systems following from the Covid-19 pandemic and control measures as perceived by knowledgeable resource persons living in low and middle income countries (LMIC) in Asia, subSaharan Africa and Latin America. Some of the key facts and potential implications are presented below.

\section{Facts \& figures}

- The WHO lists a total 512 confirmed cases, 6 deaths by 23 June ${ }^{5}$. A considerable increase compared to the data of $23 / 4$ presented in the table below.

- Current measures in Zimbabwe: social distancing, borders are fully closed, flights are partly restricted, with partial restrictions to markets and transport of goods and to flights. Schools and universities are closed and working from home has been fully implemented.

- In general, respondents reported that international linkages, international trade, food import and export were expected to decline as a result of the pandemic.

- The impact of Covid-19 depends to a large extent on the prevailing situation before the crisis started. The state of the economy, livelihoods, health services, and nutrition situation determines to a large extent the spread and intensity of Covid-19 and the capacity to respond to or recover from it.

- Covid-19 and nutrition: Both undernutrition and overnutrition entail important risk factors for health, among other reasons, through an impaired immunity response, increasing the susceptibility to infections such as Covid-19 as well as the intensity of infections, complications and mortality due to Covid-19.

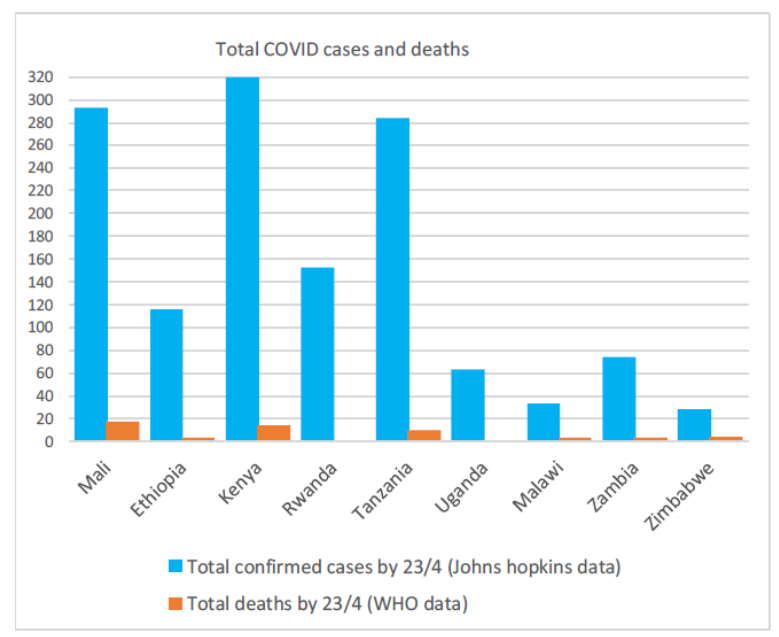

Figure 2 Covid-19 prevalence in selected countries, 23 April $2020^{6}$.

\footnotetext{
4 Lecoutere, E., I.D. Brouwer, M. van den Berg, R. Ruben. 2020. Rapid Appraisal of Food System Risk with Covid-19 measures: voices from the field. Wageningen University \& Research.

5 WHO 23/06/2020 https://covid19.who.int/region/afro/country/zw

6 Total number of cases: Johns Hopkins University \& Medicine Coronavirus Resource Center; Total number of deaths: World Health Organization (WHO).
} 


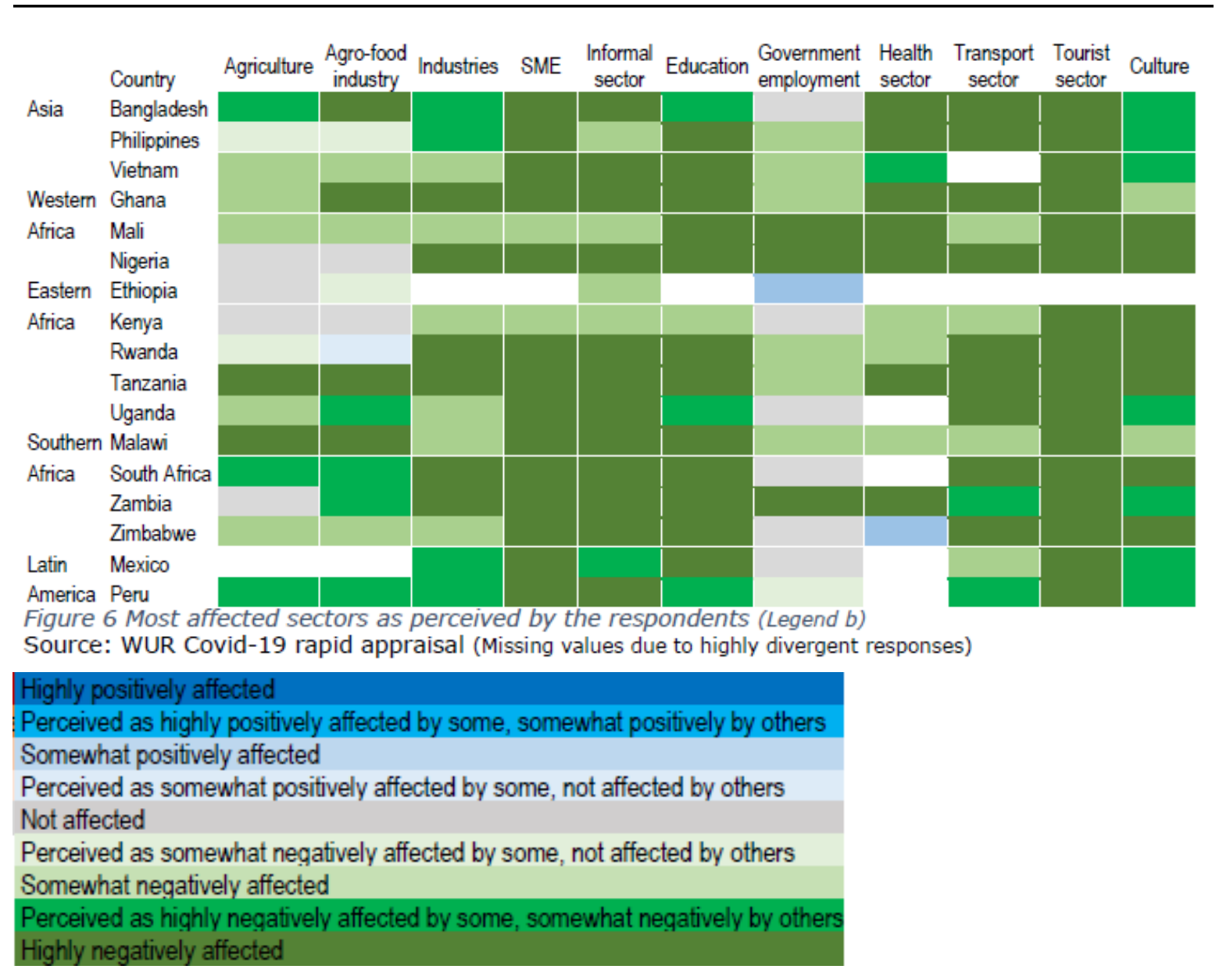

Figure 3 Most affected sectors as perceived by the respondents (see legend) ${ }^{7}$.

\section{Perceived early effects and considerations}

- Food systems, diets and health care are already facing major limitations in LMIC, and depend heavily on access to markets, institutions and social networks. Current Covid-19 mitigation measures tend to lead to early disruption of these vital linkages and are likely to affect employment opportunities, access to food and food prices.

- Rural areas are generally perceived to be less affected by the pandemic than urban areas, however those rural areas, where Covid-19 control measures are more relaxed and sanitation and health facilities are less well developed, could face high incidences of Covid-19 cases.

- While the agricultural sector and agri-food industry in Zimbabwe are thought to be negatively affected, it seems that these sectors are seen as slightly better off than SMEs, the informal sector, education, transport, tourist and culture which are all perceived as highly negatively affected sectors (see Figure 3).

- In general, it is expected that the agricultural sector and the food production will not be directly at risk due to the Covid-19 pandemic. However, according to the World Food Programme, a food crisis was already imminent, especially in Africa. Additional potential risks that have emerged due to the Covid-19 pandemic refer to the reduced access to inputs like seeds and access through broken markets, which may endanger food production in the next agricultural cycle, and the lack of labour due to mobility restriction measures.

- Food markets might become disrupted because of reduced imports of foods due to trade bans.

- Food availability at markets in urban areas is expected to decline, especially for fresh perishable foods such as fruits and vegetables (all countries) and animal sourced foods (some countries).

- Restrictions on the accessibility of markets, supermarkets and retail shops, the increased queuing and social distancing can create barriers for the population to access food and for guaranteeing variable diets.

\footnotetext{
7 Lecoutere, E., I.D. Brouwer, M. van den Berg, R. Ruben. 2020. Rapid Appraisal of Food System Risk with Covid-19
} measures: voices from the field. Wageningen University \& Research. 
- Perceived affected population groups in Zimbabwe include: youth, adult men and adult women are the most highly affected. Children and elderly are perceived as slightly affected.

- The closing of schools and lack of school meals can have implications for children as these may be an indispensable part of their diets. Based on the perceptions of our respondents, some priorities of support needed to mitigate Covid-19 effects on food and nutrition are emerging and need further elaboration and research.

\section{Relevant initiatives in Zimbabwe related to Covid-19:}

- The Youth Connekt Start-Up Tour Bus goes virtual to fight COVID-19 (UNDP): As the world is battling the coronavirus, this edition of the Start-Up Tour Bus is focusing on placing young people at the forefront in addressing the COVID-19 pandemic in Zimbabwe. Youth Connekt Zimbabwe in collaboration with the Ministry of Youth, Sports, Arts and Recreation is looking to support young entrepreneurs between the ages of 16 and 35 who have ready made products or services which can quickly be deployed in response to the pandemic. These products may be medical supplies, technology solutions, protective equipment or any other item which can be used in response to the pandemic.

Link:https://www.zw.undp.org/content/zimbabwe/en/home/presscenter/articles/the-youth-connektstart-up-tour-bus-goes-virtual-.htm/

- COVID-19 Information Hub available for free through SMS for Econet mobile users: The Ministry of Health and Child Care and UNICEF have made the Official COVID-19 Information Hub available free of charge for Econet Users via SMS. The automated messaging chatbot uses menu prompts to provide the official and latest updates including daily Ministry of Health and Child Care (MoHCC) updates, prevention and general information as well approved key messages for the general public in Zimbabwe. The purpose of SMS access to the Information Hub is to reach more people across Zimbabwe particularly in regional and rural populations who may not have smartphones or access to WhatsApp.

Link:https://www. unicef.org/zimbabwe/press-releases/official-covid-19-information-hub-availablefree-through-sms-econet-mobile-users 


\section{$3 \quad$ Climate \& Nutrition Linkages}

In 2017 , for the first time in over a decade, the number of undernourished increased due to climate change as well as conflict ${ }^{8}$. Climate change exacerbates the existing undernutrition problem in Africa and will further undermine current efforts to reduce poverty and undernutrition, particularly in SubSaharan countries ${ }^{9}$. It is projected that Sub-Saharan Africa, with a medium-high climate change, will have an additional 2.4 million undernourished children by 2050 than in a counterfactual scenario without climate change. Models estimate that the effects of climate change will reduce food availability in the low-income and middle-income countries of Africa with $122 \mathrm{kcal} /$ person/day, and more than 500,000 additional deaths globally in 2050 due to climate-related changes in diets, including decreased food intake and decreased vegetable and fruit consumption, with large regional variations ${ }^{10}$. Communities that do not have adaptation strategies in place will likely see a reversal of previous gains in reducing food insecurity and all forms of malnutrition.

Climate change, food systems, and food and nutrition security are strongly interlinked. Food systems are highly sensitive to climate, as they are both 'victims' and instigators of the effects of climate variability and longer-term climate change ${ }^{11}$. The effects of climate change and variability on food systems will, in turn, have serious implications for food system outcomes; including nutrition and health outcomes, socio-economic outcomes and environmental outcomes.

\subsection{Impact of climate on food systems}

Firstly, increased evidence shows that, climate impacts affect nutrition by influencing food production systems, through two main mechanisms:

- Extreme weather events; increased frequency and intensity of droughts, floods and storms that destroy crops, critical infrastructure (e.g. food stores), and key community assets (tools and land for food production).

- Long-term and gradual climate risks; rise in temperatures, sea-level rise, change in precipitation patterns and accelerated glacial melt affecting the quantity and reliability of water available.

Climate change models for Southern Africa project that the region will get drier and experience more extreme weather conditions such as droughts and floods ${ }^{12}$. It is affecting weather patterns and causing seasonal shifts with serious repercussions for households and communities in Zimbabwe ${ }^{13}$. Climate change will affect nutrition through its impacts on all components of the food system; food supply chains, food environments and consumer behaviour.

For food production, increased heat and water stress are expected to decrease yields and change where food can be produced. Nutrient-rich foods that are currently in short supply in many low-income

8 FAO. IFAD. UNICEF. WFP, WHO, 2017. The state of food security and nutrition in the world 2017. Building resilience for peace and food security. Rome.

9 Tirado, M.C., Crahay, P., Mahy, L., Zanev, C., D. Thomson B., C, Neira, M, Whung P-Y, Msangi, S. D. Costa Coitinho, and A. Mueller A. Climate Change and Nutrition.

10 Springmann, M., Mason-D'Croz, D., Robinson, S., Garnett, T., Godfray, H.C.J., Gollin, D., Rayner, M., Ballon, P., Scarborough, P., 2016a. Global and regional health effects of future food production under climate change: a modelling study. Lancet 387, 1937-1946. http://dx.doi.org/10.1016/S0140-6736(15)01156-3.

11 Fanzo, Jessica; Davis, Claire; McLaren, Rebecca; and Choufani, Jowel. 2018. The effect of climate change across food systems: Implications for nutrition outcomes. Global Food Security 18(September 2018): 12-19. https://doi.org/10.1016/j.gfs.2018.06.001.

12 Mbow, et al. (2019).Climate Change and Land: an IPCC special report on climate change, desertification, land degradation, sustainable land management, food security, and greenhouse gas fluxes in terrestrial ecosystems: IPCC.

13 Mashizha, T. M. (2019). Adapting to climate change: Reflections of peasant farmers in Mashonaland West Province of Zimbabwe. Jamba (Potchefstroom, South Africa), 11(1), 571-571. 
settings are particularly susceptible to water constraints, pests and diseases ${ }^{14}$ and temperature fluctuations. There will also be changes in the nutritional quality of the food supply. Carbon dioxide effects decrease the nutritional quality of many crops, especially wheat, rice, potatoes, soy and peas, by decreasing protein, iron and zinc levels. Fruits and vegetables are more perishable than grains or tubers after harvest. Livestock productivity is affected by lack of water and adequately nutritious fodder, as well as by heat and livestock diseases. Animal source products, vegetables and fruits are important sources of essential micronutrients.

Subsequent stages of the food supply chain will also experience climate-related challenges. For the food storage, processing, and transportation stage, climate change is expected to increase foodborne pathogens and mycotoxins, and food waste from extreme weather events. The effects of climate will also pose new transportation challenges such as sea level rise or increases in temperature making some roads or rail lines along the coast or that travel over permafrost or ice unusable. Extreme weather events also acutely damage infrastructure. Such effects of extreme weather particularly impact the transportation of food because it is time-sensitive and delays can cause spoilage and increase waste. As temperatures and precipitation change, some geographic areas will become less productive while others will become more so, forcing crop production to move and transportation systems to adapt in order to move food from new production locations to areas where it is needed.

Similarly, both long-term changes in climate and short-term extreme weather events will affect retail infrastructure. As a result of these disturbances, food availability and prices will be affected.

\subsection{Impact of food systems on climate change}

Dietary choices drive various production systems and have different emissions and environmental footprints. What we eat has an effect on climate change. The world's food system is responsible for about one-quarter of the planet-warming greenhouse gases that humans generate each year. That includes raising and harvesting all the plants, animals and animal products we eat - beef, chicken, fish, milk, lentils, kale, corn and more - as well as processing, packaging and shipping food to markets all over the world. As such, nutrition choices offer the potential to contribute to climate change mitigation ${ }^{15}$.

\subsection{Impact of nutrition on climate change}

Thirdly, people's health and nutritional status affect both their absorptive and adaptive capacity to the consequences of climate change. Health and nutrition status affect both the productivity of households, as well as the time burden associated with providing care to sick household and community members. Climate adaptation practices will determine a household's adaptive capacity, and in turn their vulnerability to food and nutrition in security.

\subsection{Impact of climate change on other drivers of nutrition}

When it comes to health, climate plays an important role in the transmission of many human parasitic, viral, and bacterial diseases (such as malaria, dengue, and cholera, respectively), whose spatial and seasonal distribution depend on the rainfall patterns and temperature. These diseases can decrease nutrient absorption and increase individuals' nutritional needs. Damage to health system infrastructure due to extreme weather events affects the delivery and accessibility of health care services.

\footnotetext{
14 The range of livestock and plant diseases is also expected to shift in association with changes in climate patterns.

15 Vermeulen, S. J., B. M. Campbell, and J. S. I. Ingram. 2012. 'Climate Change and Food Systems.' Annual Review of Environment and Resources 37: 195-222.
} 
With regard to the living environment, there is compelling evidence that climate change is resulting in long-term drying in some regions. Drying threatens the quantity and quality of water available for irrigation (food production), energy production (food processing), and human consumption (washing, cooking, and drinking). Water systems and their management and sanitation environments are stressed by rising sea levels, flood risks or increasing temperatures and with that the risk of vectorborne diseases, like dengue ${ }^{16}$.

The above mentioned climate-related stresses on food production, health and water systems, will impact on livelihood choices, labour options and time allocated for caregiving and other nutritionrelated activities. The framework presented in Annex 1 summarises how climate-related shocks different pathways through which climate change can impact nutrition.

16 Thomson, Madeleine; Fanzo, Jessica. 2015. Climate change and nutrition. In Global Nutrition Report 2015: Actions and accountability to advance nutrition and sustainable development. Chapter 6. Pp. 74-84. Washington, DC: International Food Policy Research Institute (IFPRI). http://ebrary.ifpri.org/cdm/ref/collection/p15738coll2/id/129450 


\section{$4 \quad$ Present Nutrition Situation in Zimbabwe}

\subsection{Trends of malnutrition}

Zimbabwe has a triple burden of malnutrition, whereby overnutrition, undernutrition and micronutrient deficiencies co-exist, as presented in Figure 4.

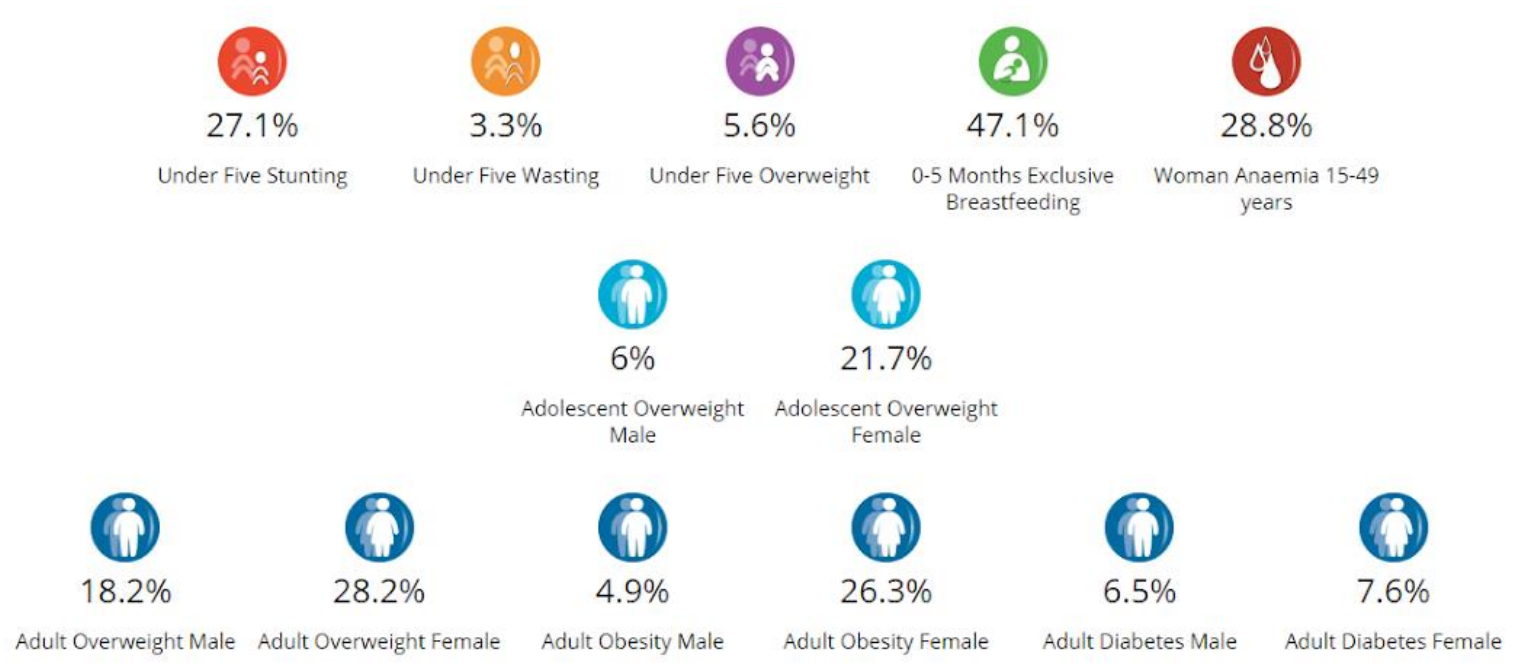

Figure 4 Nutrition situation in Zimbabwe ${ }^{\mathbf{1 7}}$.

Based on the ZimVAC (2019) ${ }^{18}$, the prevalence of child stunting (chronic malnutrition) is $23.6 \%$. With about 1 in 4 children under 5 at risk of impaired physical and cognitive growth, the stunting prevalence in Zimbabwe is ranked as 'High' according to WHO thresholds (MICS, 2019). There is a noteworthy increase in stunting from the age of 9 months, with a peak at 18 month (60\%) and a gradual decrease to $18 \%$ at 59 months (MICS, 2019). The prevalence of stunting is higher in rural areas $(26 \%)$ compared to urban $(19 \%)$, children in the poorest households $(28 \%)$ are twice as likely to be stunted than those in the richest (14\%) and pre-primary or none educated mothers $(25 \%)$ compared with those with higher education (12\%) (MICS, 2019). The figure below presents the variety in stunting levels by district. Manicaland remains a hotspot for stunting in Zimbabwe.

Micronutrient deficiency is a very widespread form of malnutrition, also in Zimbabwe, and is caused by inadequate intake of fruits, vegetables, animal-source products and other micronutrient-rich foods, which is a serious nutrition issue in Zimbabwe (see chapter on the nutrition situation analysis). The nutrition situation analysis indicated that, at a national level, only $16 \%$ of households consume ironrich foods on a daily basis, and $29 \%$ of women of reproductive age is suffering from anaemia. About one third of Zimbabwean children under 5 are estimated to be vitamin A deficient (WHO). The 2012 Zimbabwe Micronutrient Survey, showed that 19\% of children 6-59 months are vitamin A deficient, whilst $72 \%$ have iron deficiency, and $31 \%$ are anaemic, and nearly 1.5 million working age adults with anaemia suffer deficits in work performance.

17 https://scalingupnutrition.org/sun-countries/zimbabwe/ (accessed April 30).

18 Zimbabwe Vulnerability Committee, 2019 Consolidated Rural and Urban Livelihoods Assessments Report. 


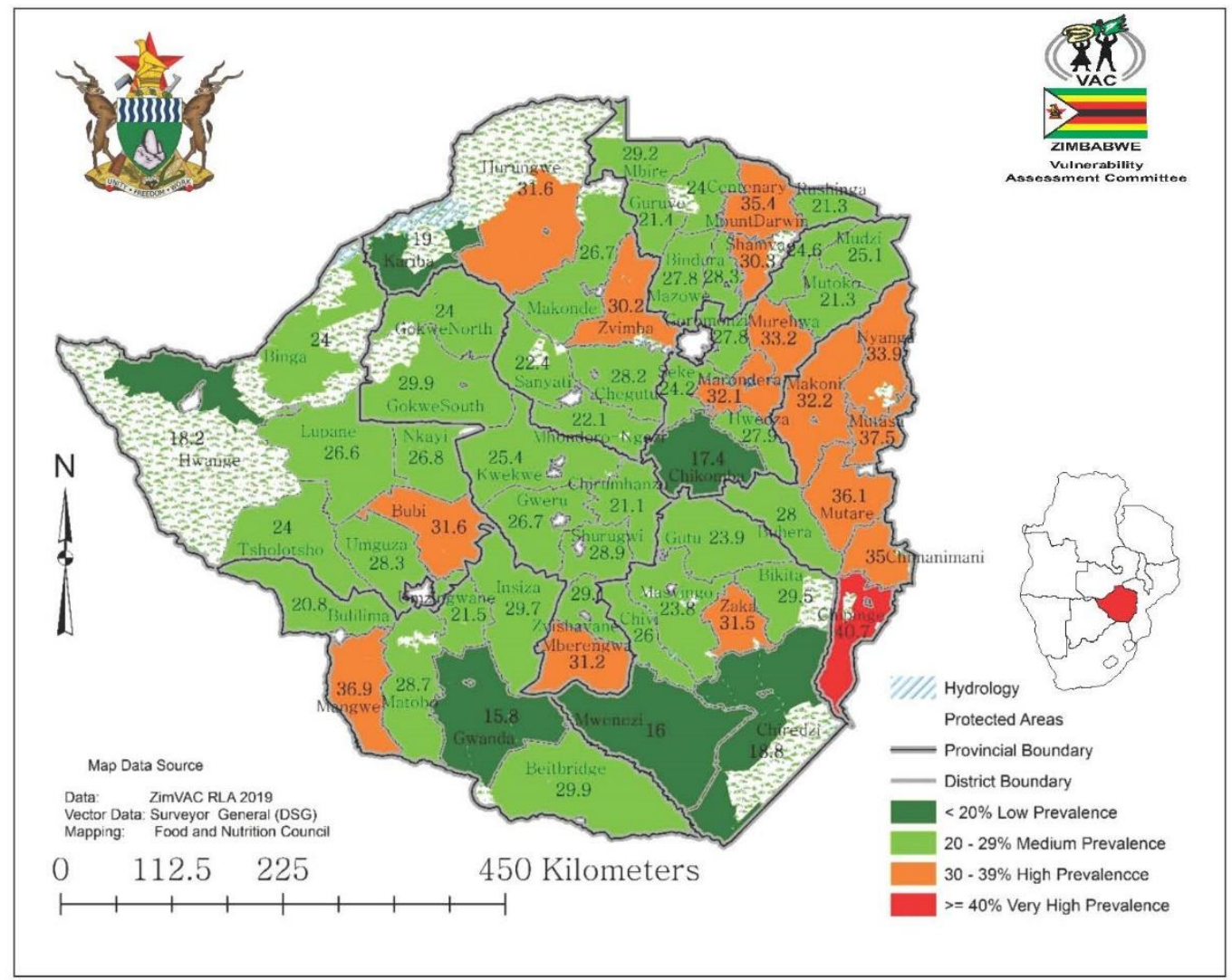

Figure 5 Prevalence of child stunting ${ }^{19}$.

Zimbabwe's adult population also face a malnutrition burden. $28.8 \%$ of women of reproductive age have anaemia, and $7.6 \%$ of adult women have diabetes, compared to $6.5 \%$ of men. Meanwhile, $25.3 \%$ of women and $4.7 \%$ of men are obese.

\subsection{Main determinants of malnutrition in Zimbabwe}

\subsubsection{Food security}

Zimbabwe ranks 109 of the 117 qualifying countries in the 2019 Global Hunger Index and is among the countries with the highest rates of undernourishment at 51.9 percent, classifying it as 'serious'. The most food insecure regions in Zimbabwe are consistent with poverty prevalence with Matabeleland North (58 percent) and Manicaland (50\%) provinces having the highest proportion of food insecure households ${ }^{20}$.

As mentioned earlier, the prevalence of child stunting is higher in rural areas (26\%) compared to urban (19\%). The increased risk for children living in rural areas has been attributed to reduced food availability caused by poor agricultural performance, lower access to food due to high levels of poverty and poor food utilisation due to lack of knowledge on how to use the available food.

\subsubsection{Food consumption patterns}

\section{Meal frequency}

The MICS survey reports on household consumption patterns for rural and urban households. The average number of meals consumed by adults in rural households $(2,231)$, is lower than the number of meals consumed by their urban counterparts $(2,405)$. The proportion of urban households that have

19 National Nutrition Survey 2018.

20 ZimVac 2019 
an acceptable food consumption score (FCS) ${ }^{21}$ is higher $(62.3 \%)$ than that of rural households $(38.0 \%)$ at $1 \%$ level of significance. There are notable disparities in dietary diversity being lower amongst the rural (13\%) compared to the urban (26\%). Only 1 in 10 children aged 6-23 months were receiving both the minimum recommended diversity of food and meal frequency. Only $17 \%$ of children aged 6-23 months were consuming foods from the recommended number of food groups per day.

\section{Household dietary diversity}

The National Nutrition Survey conducted in 2018 assessed household dietary diversity across provinces in Zimbabwe as presented in Figure 6. The national average HDDS score is 5 food groups consumed in the past 24 hours, and the highest scores are observed for Harare (7) and Bulawayo (7). Female headed households have access to a lower variety of foods than those headed by their male counterparts. Furthermore, the age of the household head increases the HDDS, and the education of the household head increases their access to food.

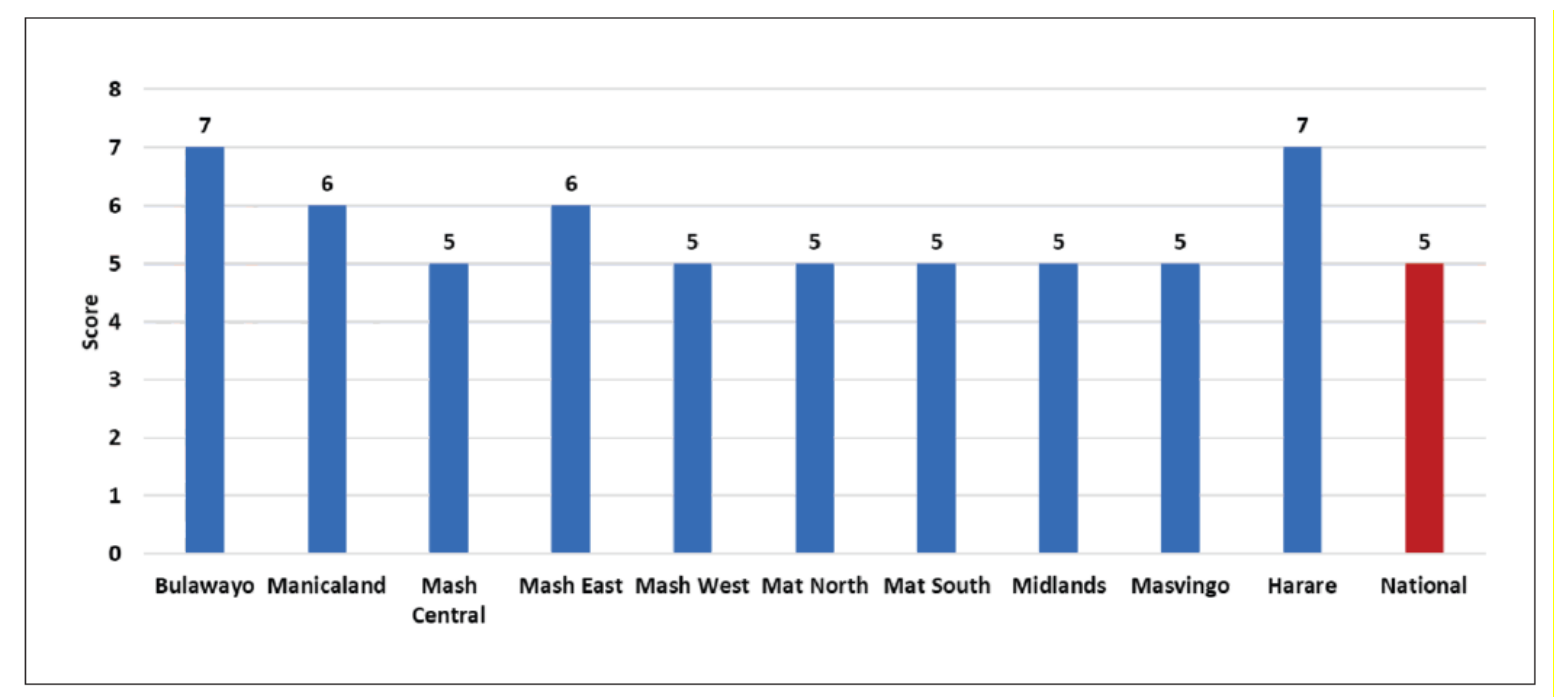

Figure 6 Household dietary diversity scores by province ${ }^{22}$.

Women are typically among the most vulnerable family members and can serve as 'sentinels' of micronutrient adequacy among other household members. Minimum Dietary Diversity for Women (MDD-W) is a food group diversity indicator that reflects one key dimension of diet quality micronutrient adequacy - among women 15 to 49 years of age, and gives a broad indication of dietary patterns for women. Figure 7 shows that in most provinces, the majority of women do not meet the minimum dietary diversity of at least five essential food groups. Matabeleland North and South, and Mashonaland West report the lowest diet quality for women.

21 The 'Food consumption score' (FCS) is a score calculated using the frequency of consumption of different food groups consumed by a household during the 7 days before the survey. There are standard weights for each of the food groups that comprise the food consumption score.

22 National Nutrition Survey 2018. 


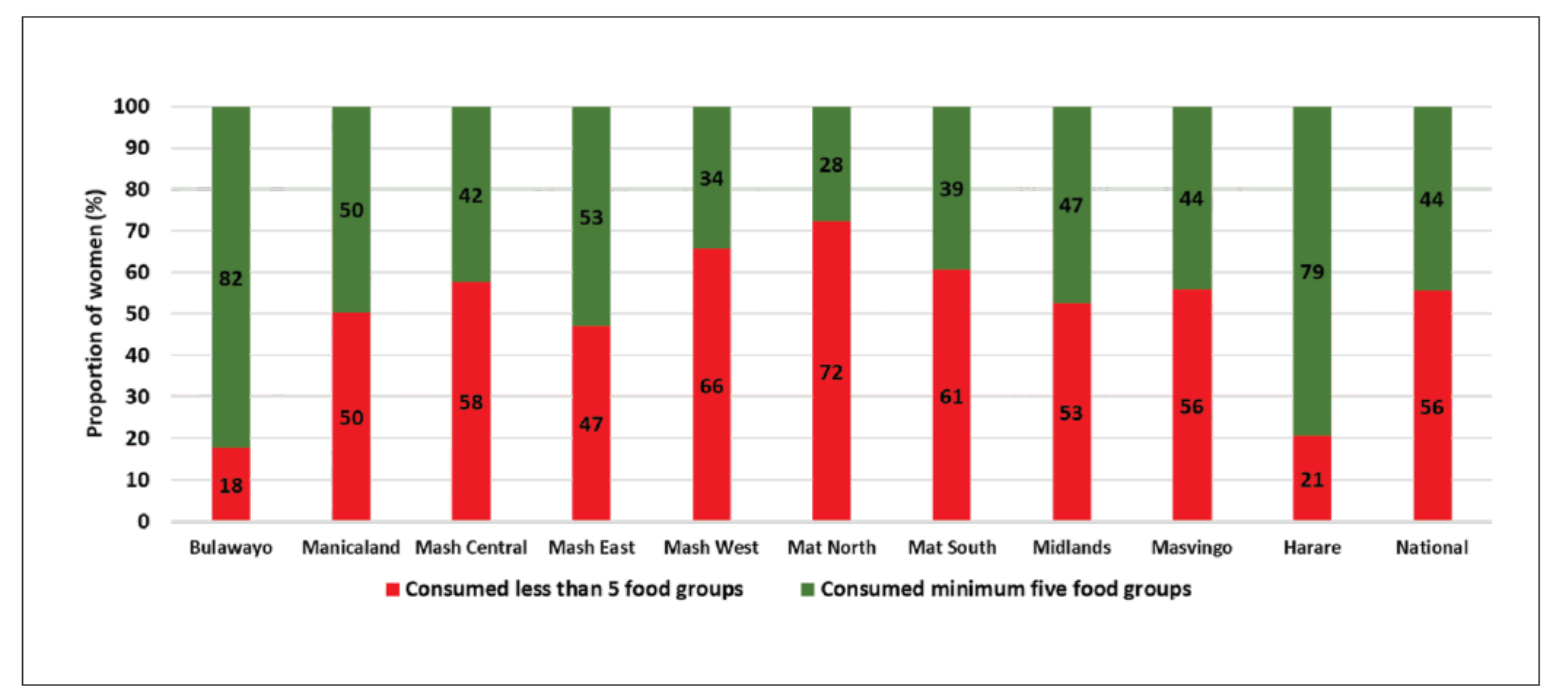

Figure 7 Women's dietary diversity by province ${ }^{23}$.

The food consumption score covers a longer time frame, as it probes on consumption over the past seven days. The score classifies household consumption into poor, borderline and acceptable. In 2018, slightly more than half of the households had food consumption scores rated as acceptable. Nationally, $17 \%$ of households were consuming poor diets and the province with the highest proportion of households consuming poor diets was Matabeleland North (37\%). It is important to note that the quality of the diets in Zimbabwe has deteriorated when compared to 2010. There was a decrease in the proportion of households consuming an acceptable diet from 67\% in NNS 2010 to 55\% in 2018. The proportion of households in the poor and borderline categories increased in the year 2018 compared to $2010^{24}$.

\subsubsection{Consumption of specific foods}

The FCS can also be used to assess consumption of specific food groups. Food groups most frequently consumed are maize and vegetables. However, the key informant interviews confirmed that variety within food groups is still low ${ }^{25}$. For example, households will consume vegetables on a regular basis, but with limited variation in the types of vegetables. It is the variety of food within and across food groups however that can ensure an adequate intake of micronutrients. Dairy products, pulses and eggs are least consumed, see also Figure 8.

According to the National Nutrition Survey of 2018, the proportion of households consuming vitamin A rich foods seven days prior to the survey was $92 \%$ of which $19 \%$ consumed sometimes and $74 \%$ consumed at least daily. Matabeleland North is the province with the highest proportion of households (18\%) who did not consume vitamin A rich food prior to the survey ${ }^{26}$. For protein and iron-rich foods, the figures are more concerning. Only $34 \%$ of the households consumes protein-rich foods ${ }^{\mathbf{2 7}}$ on a daily basis. Matabeleland has the highest proportion of households who did not consume iron-rich foods in the 7 days prior to the survey whereas it is among one of the livestock rearing provinces. Similarly, intake of iron-rich foods is very low in Matabeleland North and Mashonaland central (with $55 \%$ and $45 \%$ of households reporting no intake of iron-rich foods). At the national level, only $16 \%$ of households consume iron-rich foods on a daily basis.

23 National Nutrition Survey 2018.

24 National Nutrition Survey 2018.

25 Dietary diversity within food groups is not captured with the FCS or HDDS.

26 When respondents were asked on how many out of the past 7 days they consumed specific food groups.

27 Meat/fish/egg/dairy/pulses. 


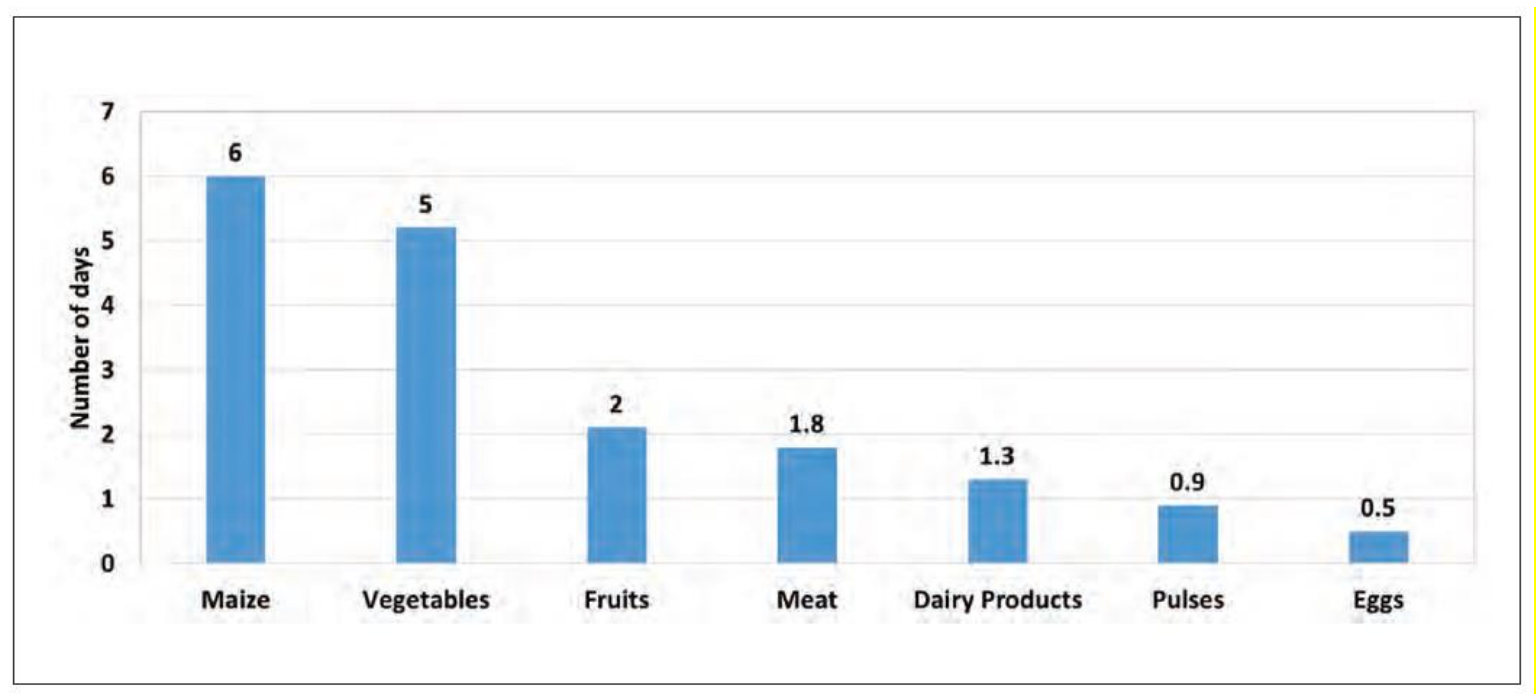

Figure 8 Household consumption of individual food groups, reporting period 7 days, in Zimbabwe ${ }^{28}$.

Table 1 Consumption of specific foods rural versus urban ${ }^{29}$.

\begin{tabular}{llll} 
Type of food & National & Urban & Rural \\
\hline Iron-rich foods ( 6 days past week) & $16 \%$ & $27 \%$ & $8 \%$ \\
\hline Vitamin A rich foods ( 6 days past week) & $74 \%$ & $72 \%$ & $65 \%$ \\
\hline Protein-rich foods & $34 \%$ & $46 \%$ & $24 \%$ \\
\hline Average household dietary diversity score (out of & 5 & 5 & 4 \\
12 food groups) & & 1 & 1 \\
\hline Average number of days beans were consumed & 1 & 1 & $\mathrm{~N} / \mathrm{A}$ \\
\hline Average number of days eggs were consumed & 1 & 1 & 1 \\
\hline Average number of days milk was consumed & 1 & 1 & 1 \\
\hline Average number of days fruits were consumed & 2 & 3 & 1 \\
\hline Average number of days meat was consumed & 2 & 5 & 5 \\
\hline Average number of days vegetables were & 5 & 5 & 5 \\
\hline consumed & & 5 & \\
\hline Average number of days cereals were consumed & 6 & & \\
\hline
\end{tabular}

In urban areas, average HDDS has decreased from 7 in 2019 to 5 in 2018, indicating a deterioration of urban diets. The HDDs score is lower in rural areas as compared to urban areas. The consumption of iron-rich foods and protein-rich food is very low in rural areas.

The Global nutrition report has compared the consumption of food groups and components in Zimbabwe, with global averages and averages for Africa. The figure below shows intake level compared to the theoretical minimum-risk exposure level (TMREL). By definition, TMREL is the exposure level (i.e. intake level of a food or nutrient) that minimises the risk of death from all causes related to a single risk factor. The analysis shows that consumption of fruits, milk, nuts and seeds, vegetables and whole grains is generally very low. As a result, the intake of omega 3 fatty acids and calcium is also on the low end. It is remarkable that the average consumption of legumes is lower than in the rest of Africa. In other words, due to low consumption of these nutritious food groups, consumers are missing out on the nutritional benefits for reducing the risk of micronutrient deficiencies and non-communicable diseases. At the same time, the consumption of sugar sweetened beverages is far beyond the minimum risk exposure. High intake of salt is also a high dietary risk factor.

\footnotetext{
28 National Nutrition Survey 2018.

29 Based on ZimVac 2019 Rural Livelihoods Assessment Report and ZimVac 2019 Urban Livelihoods Assessment Report.
} 


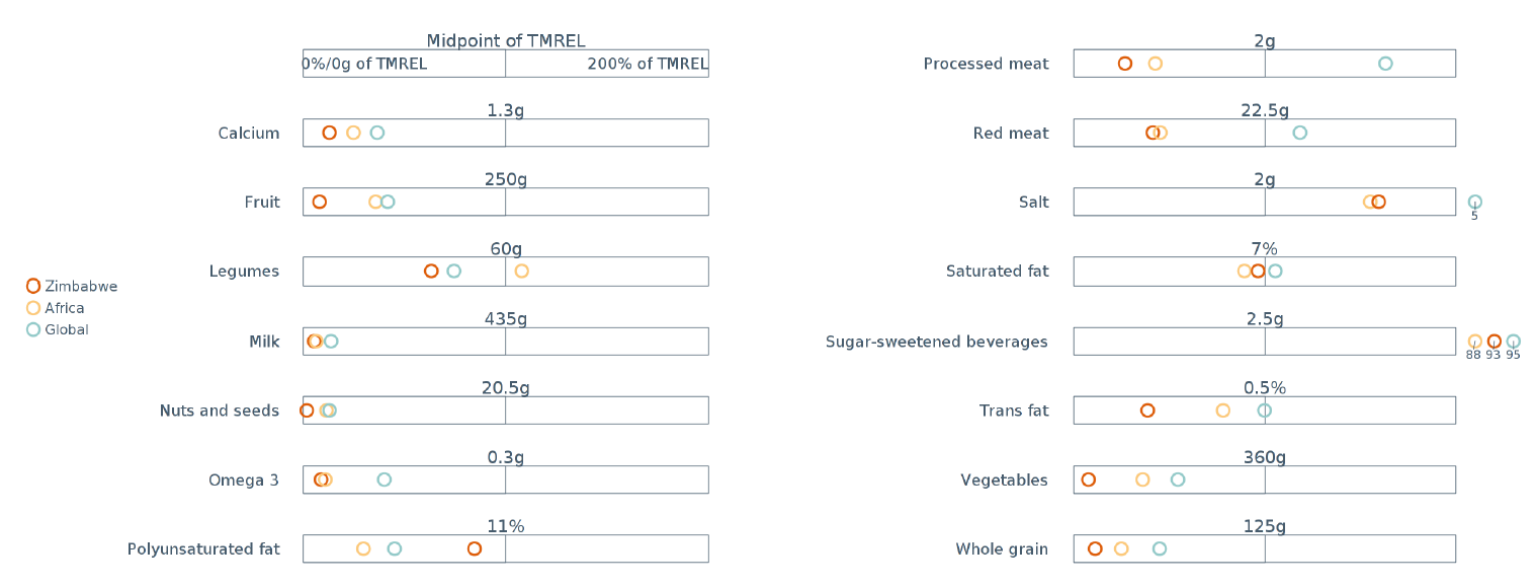

Source: Global Burden of Disease, the Institute for Health Metrics and Evaluation.

Figure 9 Consumption of food groups and components ${ }^{30}$.

Based on this analysis, it can be concluded that there is a need to increase consumption of:

- Nutrient-rich fruits

- Protein-rich foods from both plant and animal sources

- Nuts and seeds

- Nutrient-rich vegetables

- Whole grains

- Iron-rich foods

The overview ${ }^{31}$ below displays which production systems are currently prioritised when it comes to land use for agriculture, plus the respective yields. This prioritisation is not in line with the main dietary gaps.

\section{Production Systems Key for Food Security in Zimbabwe ${ }^{(6)}$}

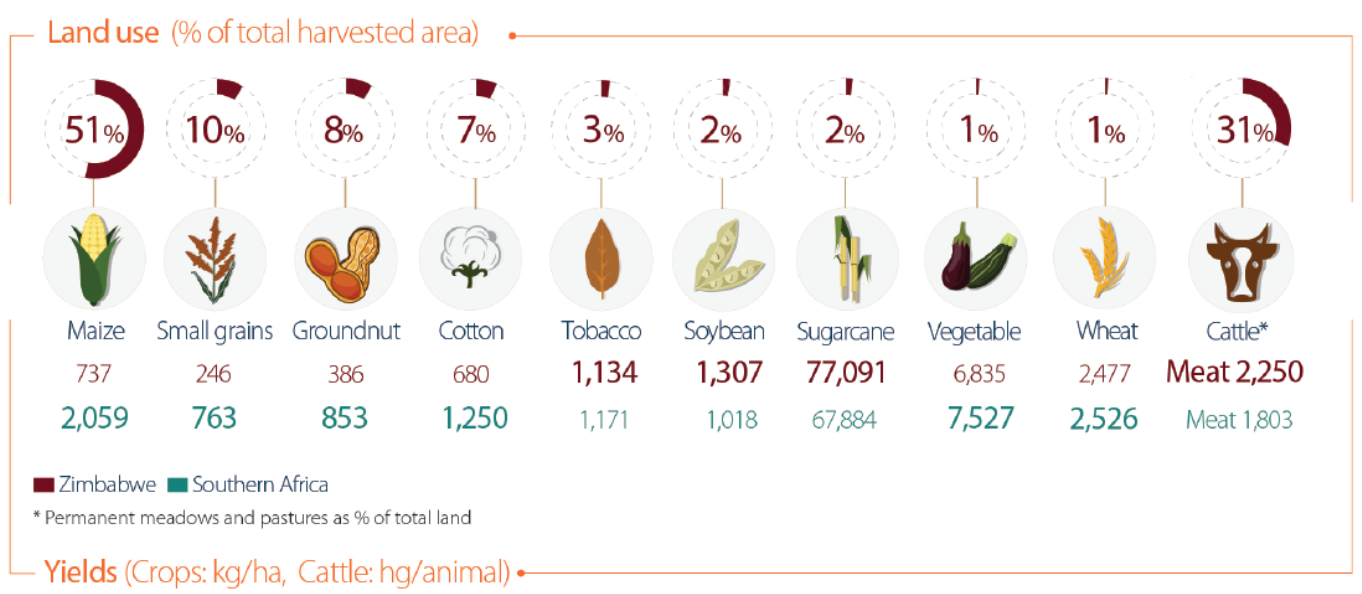

\subsubsection{Care}

\section{Infant and young child feeding practices MICS 2019}

Figure 10 summarises the infant and young child feeding practices in Zimbabwe. The majority of the infants receive breastfeeding within one hour after birth. To achieve optimal growth, development and health, the WHO recommends to breastfeed exclusively during the first 6 months. Two in five infants

30 Global nutrition report 2018, Profile for Zimbabwe.

31 Climate smart agriculture profile Developed by World Bank, CGIAR Research Program on Climate Change, Agriculture and Food Security, International Center for Tropical Agriculture. 
under the age of six months are receiving only breastmilk. Most infants are introduced to complementary feeding in a timely manner, however, the dietary diversity is inadequate. In Zimbabwe, children from the richest households are 5 times more likely to have the minimum dietary diversity than those from the poorest households. The education level of mothers is a strong determinant of dietary diversity of children under two.

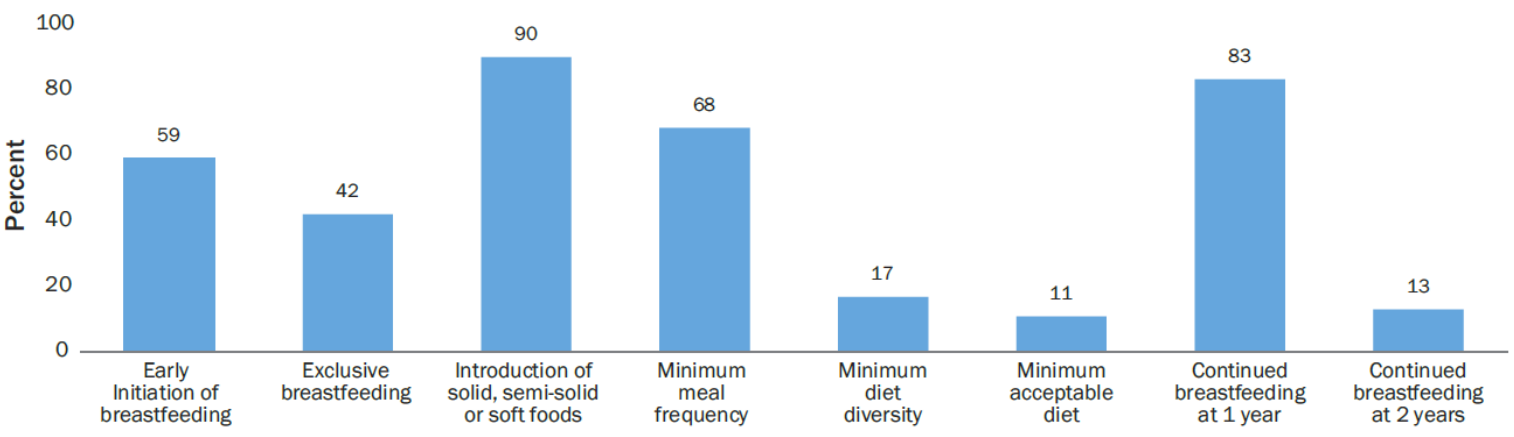

Figure 10 Infant and young child feeding practices in Zimbabwe ${ }^{32}$.

Infant and young child feeding practices vary significantly by region. For example, the following image shows the variation by district in the proportion of children receiving the minimum acceptable diets (a minimum acceptable diet meets the minimum recommended diversity of food and meal frequency for young children).

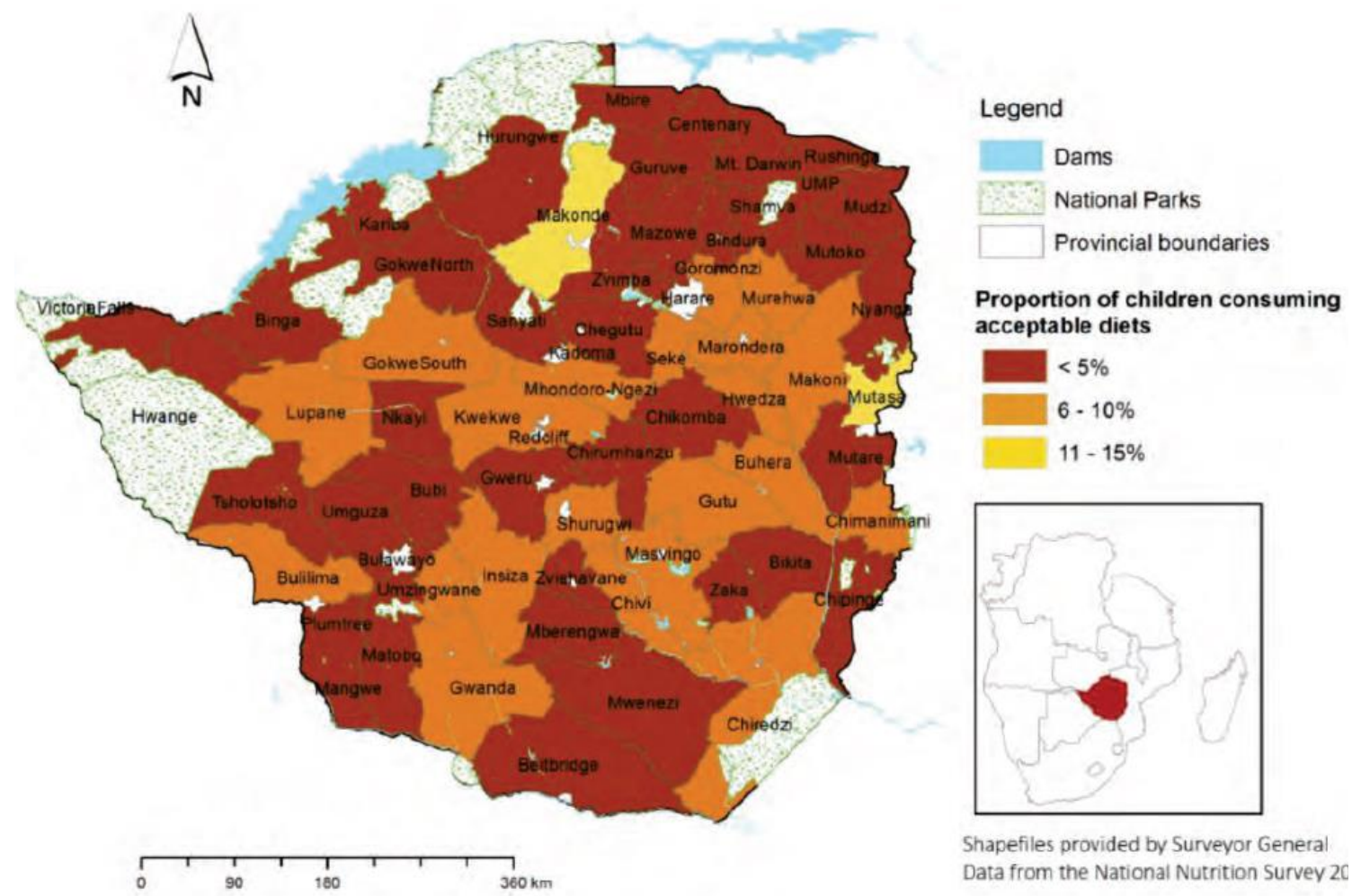

Figure 11 District comparison of proportion of children aged 6-23 months receiving acceptable diets. 


\subsubsection{Adolescent nutrition}

The Adolescent Nutrition Technical Working Group (ANTWG) analysed the current state of evidence around adolescent nutrition policy, strategies and programming in Zimbabwe ${ }^{33}$. They concluded that data for this age group is very limited, and no nationally representative adolescent nutrition-focused data has been collected. However, there is data available for anaemia, nutritional status for the age group 15-19 years gleaned from the Zimbabwe Demographic Health Survey (ZDHS). Subnational studies mainly collect data on adolescent sexual and reproductive health indicators. An analysis of the ZDHS data shows that thinness in boys aged 15-19 years is higher in those living in rural areas, the poor, those with no education or primary school and those unemployed. Based on the BMI-for-age scale between 2010-11 and 2015 non-pregnant girls and boys aged 15-19, the prevalence of thinness has also decreased from $2.0 \%$ to $0.6 \%$ and $12.6 \%$ to $8.7 \%$ respectively ${ }^{34}$. Table 2 below shows that the prevalence of overweight and obesity among non-pregnant adolescent girls varies most when comparing girls living in urban and rural areas.

Table 2 Prevalence of overweight/obesity in non-pregnant adolescent girls ${ }^{35}$.

\begin{tabular}{lll} 
Factor & & Prevalence (\%) \\
Area of residence & Urban & $25.2 \%$ \\
\cline { 2 - 3 } & Rural & $10.8 \%$ \\
\hline \multirow{2}{*}{ Wealth status } & Wealthy & $18.8 \%$ \\
\cline { 2 - 3 } & Poor & $9.2 \%$ \\
\hline \multirow{2}{*}{ Educational status } & Secondary or higher & $17.2 \%$ \\
\cline { 2 - 3 } & No education and primary & $9.1 \%$ \\
\hline Employment status & Employed & $23.0 \%$ \\
\cline { 2 - 3 } & Unemployed & $13.8 \%$ \\
\hline
\end{tabular}

\subsubsection{Gender}

The total population of Zimbabwe is 13.06 million, of which $52 \%$ are female and $48 \%$ are male. About $65 \%$ of households in Zimbabwe are male-headed households versus 35\% female-headed. Literacy rates are high in Zimbabwe: $97 \%$ for women and 98\% for men. Maternal mortality is at 960 per 100,000 live births.

FAO assessed the national gender profile of agricultural and rural livelihoods in Zimbabwe ${ }^{36}$. The report states that 'about $86 \%$ of women in Zimbabwe depend on land for livelihood and food production for their families. Rural women in Zimbabwe make the majority of smallholder farmers. Traditionally, all married male members of a community have the right of access to arable plots and the right of allocation rests with the local government authorities and traditional leaders operating within the jurisdiction of the Rural District Council Act (1988) and the Communal Lands Act (1982). Land ownership in Zimbabwe is heavily skewed towards men. The landowners automatically have the right to the water if available on their land.

In Zimbabwe, the total number of people employed in agriculture, fisheries and forestry is $3,573,893$, of which $45.4 \%$ are men and $54.6 \%$ are women. The percentage for females is high because they are mostly unpaid family workers. While men in Zimbabwe eclipse women in terms of ownership of more valuable livestock, decision-making and control of livestock production, women's ownership of smaller livestock (like chicken) is greater. Both women and men participate in crop and horticultural production and marketing, but women and girls participate more in grading and

33 Matsungo TM, Muderedzwa TM, Mugariri FM, Chopera P and Chipurura B (2019). A landscape analysis on readiness to accelerate action on adolescent nutrition programming in Zimbabwe. The Adolescent Nutrition Technical Working Group (ANTWG), Harare, Zimbabwe.

34 Benedict, R. K. and Schmale, A. (2018) 'Adolescent nutrition 2000-2017: DHS data on adolescents aged 15-19 DHS comparative', (June).

35 Idem.

36 FAO. 2017 national gender profile of agricultural and rural livelihoods Zimbabwe Country Gender Assessment series. 
packaging. Both women and men are also active in forestry farming, but the women's roles are mainly in nursery development and management'.

Some of the main identified gender constraints in the agricultural value chain are ${ }^{37}$ :

- Production: lack of land ownership, land grabbing by male relatives, low paid employment, limited assets, lack of livestock ownership, large share of agricultural labour.

- Markets: lack of facilities, safety issues and unfair prices.

- Transportation: unsafe transportation, travelling at night.

- Limited participation in decision-making processes: at household and community. Decision around farm management, investments, community development.

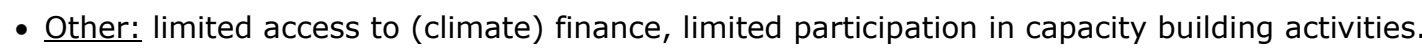

The FAO assessment concludes that patriarchal systems, cultural norms and traditions play a huge role in gender dynamics that shape the status of women in Zimbabwe. This is mostly evident in women's access to and control of resources, gender roles, and participation in decision-making, rural institutions and development planning.

\subsubsection{WASH}

A growing body of evidence indicates that access to safe drinking water, sanitation, and hygiene (WASH) services has an important positive impact on nutrition. Among rural households, 33\% sources their drinking water from unprotected sources ${ }^{38}$ or surface water, peaking in Matabeleland North and Matabeleland South. Access to improved water sources is much lower in rural households as compared to urban households. The percentage of the population using basic drinking water services increases with socio-economic status. As shown in the pie chart below, water collection is primarily the responsibility of women $15+$ years $(79 \%) .{ }^{39}$

\section{Who collects water?}

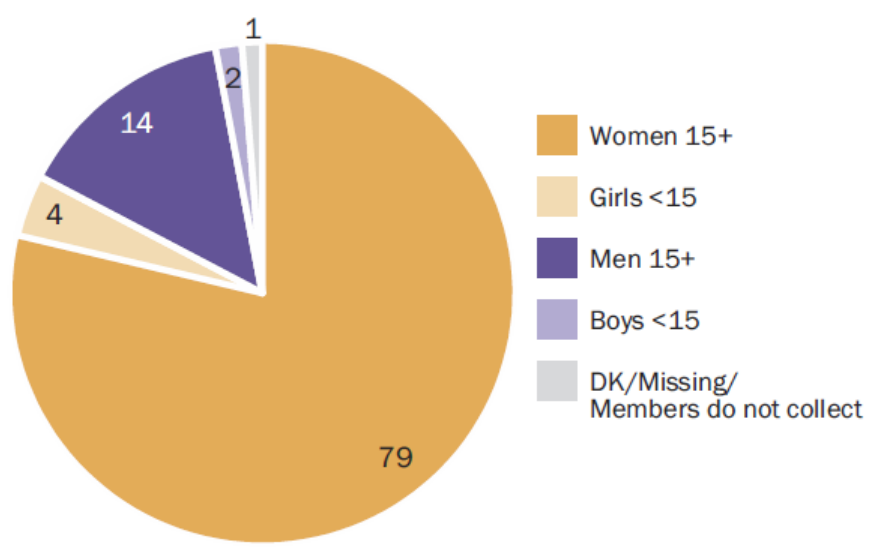

Figure 12 Responsibility for water collection.

The practice of open defecation is high across most rural provinces, with over a third of households across the country and two thirds in Matabeleland North. The majority of the rural households have a handwashing facility on their premises, but for about one third of the households, the facility lacks water and/or soap. Female headed households are $12.5 \%$ less likely to practice open defecation than male headed households.

\footnotetext{
Interview with Dr. Sandra Bhatasara - University of Zimbabwe.

8 Unprotected dug wells or unprotected springs.

39 MICS 2019 summary report.
} 
The prevalence of diarrhoea, often as a result of poor WASH practices, is significantly higher (6.9\%) in urban areas than rural areas ${ }^{40}$. Diarrhoea increases the risk of malnutrition, as it hampers nutrient absorption. The high incidence of diarrhoea in children under 5 years can be attributed to the poor quality of water sources in urban areas. The high incidence of waterborne diseases such as diarrhoea, typhoid $^{41,42}$ and cholera $43,44,45$ in urban areas in Zimbabwe is an indication of high contamination in water from the 'improved water sources' (tap and borehole water) in urban areas in Zimbabwe, especially Harare.

\subsubsection{Vulnerability to malnutrition (by area and household type)}

Based on the ZimVac of 2018 and 2019, and the MICS 2019 reports $^{46}$, the most vulnerable households for malnutrition are:

- Female headed households,

- Child headed households,

- Households headed by aged, unemployed, uneducated, widowed and chronically ill household heads,

- Households located in the rural areas have an increased likelihood of suffering from malnutrition,

- Households who are members of the apostolic religious group.

As for diet quality, the nutrition situation analysis shows that the worst off provinces are Mashonaland Central and South, and Matabeleland North and Matabeleland South. For WASH, Matabeleland North is most challenged, considering the data on open defaecation and sources of drinking water.

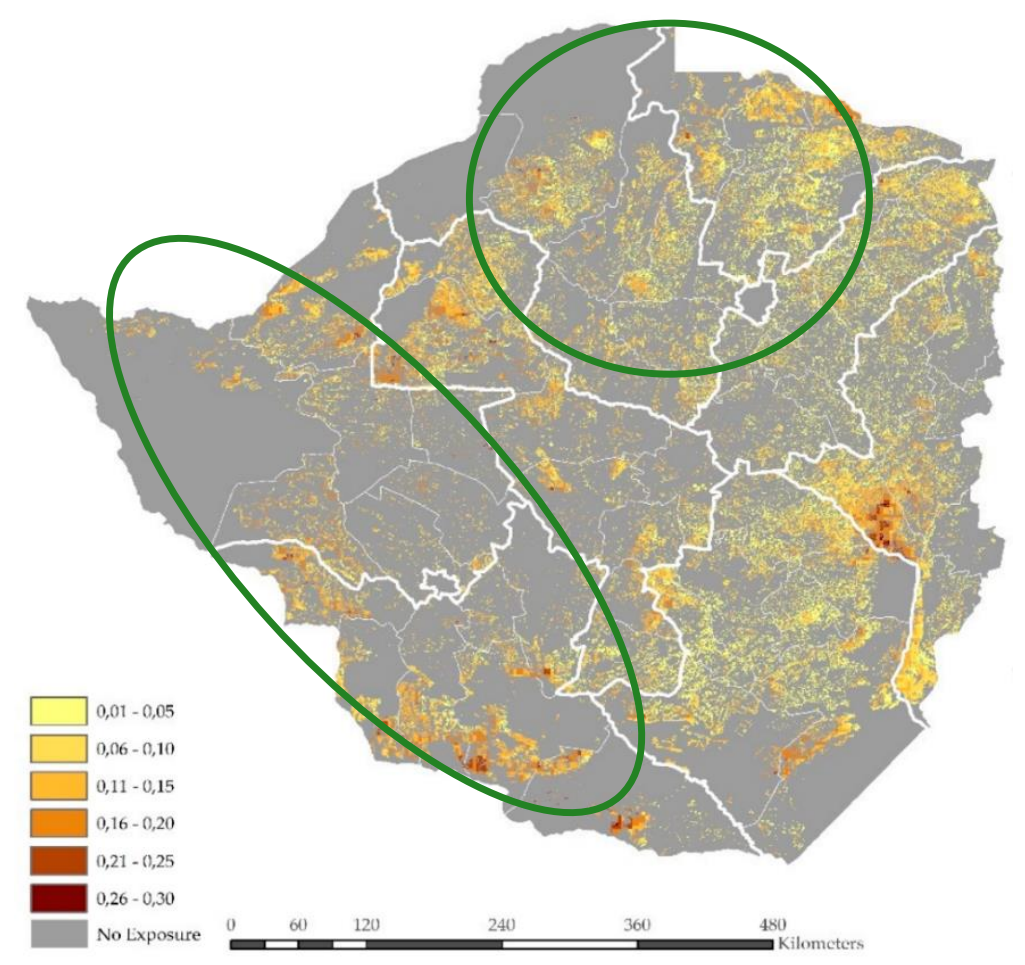

Figure 13 Regions vulnerable to malnutrition.

\footnotetext{
MICS 2019.

N'cho et al. (2019). doi.org/10.15585/mmwr.mm6802a5.

2 Muti et al. (2014) doi:10.11604/pamj.2014.18.309.4288.

43 https://www.who.int/csr/don/05-october-2018-cholera-zimbabwe/en/.

44 https://www.unicef.org/zimbabwe/topics/cholera.

45 Chimusoro et al. (2018). DOI: 10.5772/intechopen.79794.

46 Zimbabwe 2019 Multiple Indicator Cluster Survey Report.
} 


\subsection{Policy arena nutrition}

Key policies for food and nutrition security are the Food and Nutrition Policy (2012); the Zimbabwe National Nutrition Strategy (2014-18) ${ }^{47}$, and the Food and Nutrition Council guidance document on Community Based Multi-Sectoral Approach to Address Food and Nutrition Insecurity in Selected Vulnerable Districts of Zimbabwe with a Special Focus on System Strengthening.

The national nutrition strategies recognises the impact of climate on food and nutrition security with the following article; Zimbabwe experiences moderate to severe drought conditions regularly. These conditions have an impact on food and nutrition insecurity and are made worse by climate change that has become a regular phenomenon in many places of the world. Additionally, natural disasters and man-made disasters have also increased the chances of food and nutrition insecurity. The National Nutrition Strategies calls for a number of measures to mitigate these problems such as disaster risk reduction, early warning systems, development of drought-resistant crops such as small grains. These strategies have been developed to increase community resilience to shocks through supporting agrobased sustainability programmes targeted at ecologically fragile regions of the country. Unfavourable climate and agro-ecological conditions were identified as a major risk for the NNS goal to increase the proportion of households consuming safe and acceptable diets all year round.

One of the specific objectives of the Community Based Multi-Sectoral Approach to Address Food and Nutrition Insecurity is to contribute to resilience of communities to respond to shocks and mitigate the risks related to FNS. Apart from that, no specific reference is made to the impact of climate change on nutrition, or the need for climate change adaptation measures to ensure food and nutrition security.

Key institutions for nutrition are the National Steering Committees on Food and Nutrition Security; National Task Force on Food and Nutrition Security; Advisory Group for Food and Nutrition Security; Zimbabwe National Nutrition Survey and Zimbabwe Vulnerability Assessment Committee; Consumer Council; Ministry of Health; Ministry of Education. But also, the Ministry of WASH.

Under the lead of the Food and Nutrition Council of Zimbabwe, Food and Nutrition Security Committees (FNSCS) have been established at National, Provincial, District, and ward level. These are institutional structures for coordinated multi-sectoral implementation of the Food and Nutrition Security Policy and programmes. The committees are chaired by agriculture, with the nutrition department being secretariat of the committees. To date, 8 provincial, 42 rural district and 260 ward FNSCs have been established and resuscitated. ${ }^{48}$ The roles of the FNSCs include the coordination of food and nutrition security programmes; prioritising food and nutrition security responses in line with the FNSP, monitoring allocation of resources and gaps, monitoring the implementation of programmes, providing technical advice to lower level structures. Figure 14 shows the structure of the FNCs at all government levels.

The following networks have established under the Scaling Up Nutrition movement in Zimbabwe; the Scaling Up Nutrition and Academia Platform (SUNRAP), Sun Business Network, Sun Civil Society Network (ZCOSUNA), NGO Network and the Donor Network.

47 The second national nutrition strategy is currently still under review.

48 http://fnc.org.zw/ 


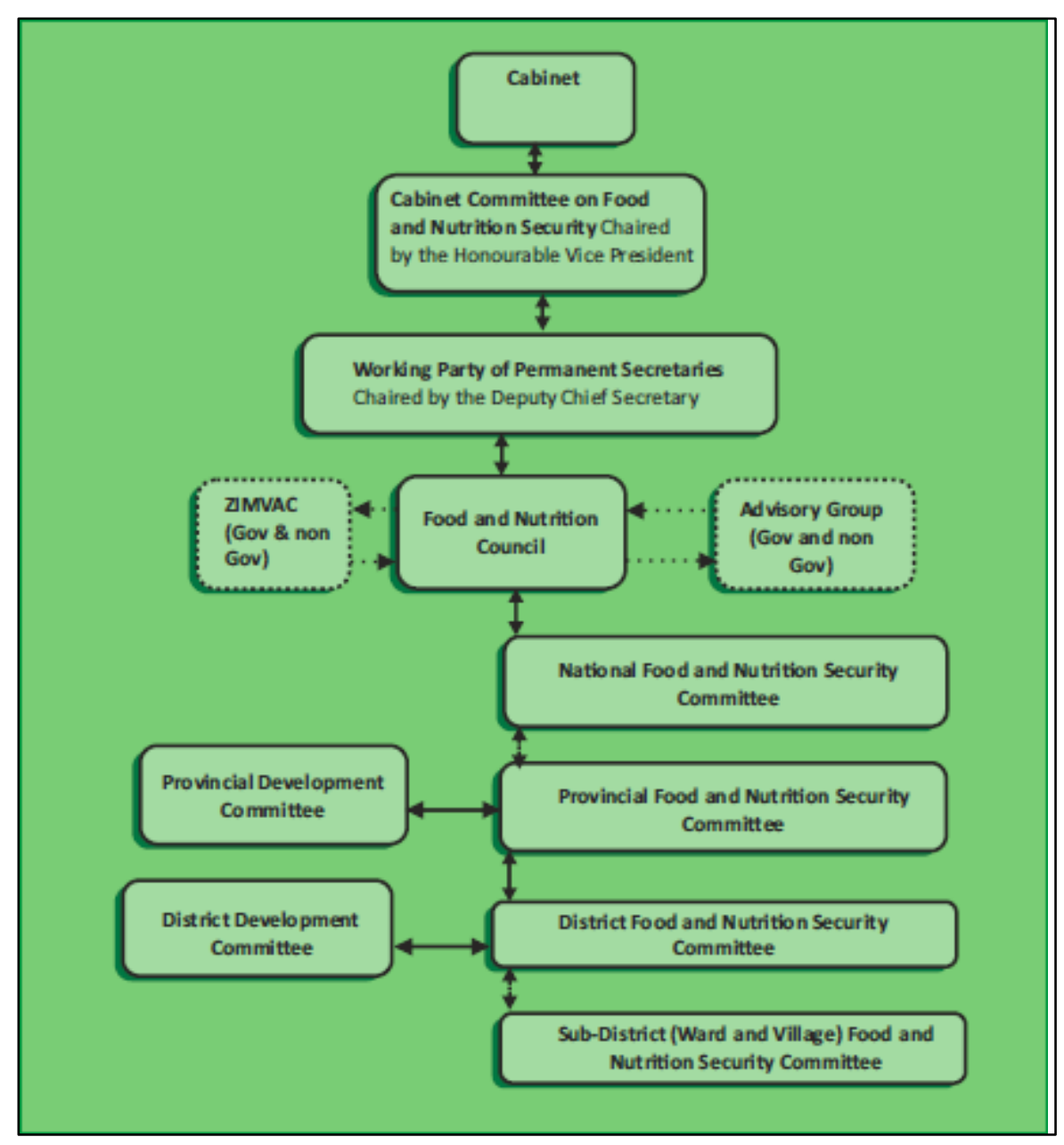

Figure 14 Structure of FNSCs at all government levels.

The ZimVAC committee, is a consortium of Government, UN agencies, NGOs and other international organisations, that coordinates food and nutrition security assessments in Zimbabwe, in order to inform multi-sectoral actions that address food and nutrition security.

In 2018, the Renewed Efforts Against Child Hunger initiative (REACH) conducted a stakeholders and nutrition action mapping, conducted by the $\mathrm{REACH}$ project ${ }^{49}$. This stakeholder mapping was organised around the core nutrition actions, based on the focus areas of the national nutrition plan for Zimbabwe. The mapping included 19 districts. Annex 8.7 includes an overview of a selection of the core nutrition action and stakeholders which are most relevant for nutrition mainstreaming interventions in IFAD's portfolio in Zimbabwe.

49 REACH. 2018. Zimbabwe stakeholder and nutrition action mapping. 


\section{$5 \quad$ Present Climate Situation in Zimbabwe}

A brief overview is given on the current climate change impacts and vulnerabilities and the future climate projections (Mid-Century future is defined by the period 2040-2069) for Zimbabwe. The information has been derived from interviews with various stakeholders and the climate risk analysis study $(\mathrm{CRA})^{50}$ for Zimbabwe carried out by the University of Cape Town.

\subsection{Climate trends and projections}

The climate risk analysis study (CRA) indicates that there are many spatial differences to be found in relation to impacts of climate variables and levels of vulnerability which have to be carefully taken into account when designing climate action plans for specific provinces. However, there are some general observations to be made regarding climate trends and projections in Zimbabwe ${ }^{51},{ }^{52}$

- Temperature: Mean annual temperature increased by $0.4^{\circ} \mathrm{C}$ between 1900 and 2000

- All provinces in the study area are predicted to experience increasing temperatures throughout the year. Mean temperatures are predicted to increase across all provinces by at least $1.8^{\circ} \mathrm{C}$ during the period from 'Historical' to 'MC 2050' timepoints. The hottest months of October, November and December are predicted to increase by $2-2.7^{\circ} \mathrm{C}$, relative to a Historical average of $24.8-25.5^{\circ} \mathrm{C}$. Similar increases of $1.8-2.2^{\circ} \mathrm{C}$ are predicted for all other months of the year.

- Rainfall: Overall decline of $\sim 5 \%$ in rainfall over the last century.

- All provinces are predicted to experience increasing delays or inconsistencies in the onset of rainfall, and an overall decrease in the annual and seasonal precipitation between the present day and the 'Mid-Century' future ( 2040-2069).

- Average monthly rainfall is predicted to decrease in all provinces for the months of September, October and November, which are considered to be the start of the rainy season.

- These results may be indicative of a delay in the onset of the traditional rainy seasons, or alternatively a decrease in the effective duration of the rainy season.

- Overall, the predicted trend for annual precipitation is a long-term trend of decreasing rainfall, as well as possible shifts in the timing of rainy seasons. Modelled predictions for national average precipitation indicate a decrease of mean annual rainfall from $\sim 620 \mathrm{~mm}$ to $\sim 526 \mathrm{~mm}$, representing a decrease of $\sim 95 \mathrm{~mm}$ or $15 \%$ - the predicted decrease of rainfall across the country's provinces and Natural Regions ranges from $\sim 14-19 \%$.

- Extreme weather events: In recent years, an increase in intensity of mid-season dry spells and/or drought. Also an increase in the number of hot days and decrease in the number of cold nights.

- Total annual hot days of temperature above $35^{\circ} \mathrm{C}$ will rise by 38.5 days in 2050 (RCP 8.5).

\subsection{Climate change impacts}

As the list above suggests, these climate-related trends are predicted to continue into the future, but are currently already profoundly impacting various sectors, ecosystems and its people.

Extensive Climate Risk Assessment for Zimbabwe has been carried by Cape Town University commissioned by IFAD.

University of Cape Town. 2019. Climate Risk Assessment ZIMBABWE.

52 World Bank. 2020. Climate Knowledge Portal Zimbabwe:

https://climateknowledgeportal.worldbank.org/country/zimbabwe. 


\subsubsection{Agriculture}

- The majority of the agriculture (70-80\%) is rain-fed, which makes the sector highly sensitive to climate change impacts, especially precipitation variability and climate-induced natural hazards ${ }^{53}$.

- The expected impacts of changes in rainfall patterns, rising temperatures and frequent heat waves, droughts and floods will destabilise agricultural production either as in decreased yields or crop failure. Especially the heat and drought-sensitive crops such as maize and wheat are more sensitive.

- Climate change may also delay the onset of rainfall relative to the traditional agricultural calendar, thus changing the timing of various agricultural activities such as field preparation and sowing of seed.

- The rain-fed agricultural growing season is characterised by monthly rainfall deficits and will likely result in changes to local crop choices and agricultural practices by the year $2050^{54}$.

\subsubsection{Crop suitability}

- See annex 8.3 for a complete overview of crop suitability in relation to nutrition, climate and gender $\&$ youth considerations.

- The CRA study for Zimbabwe predicts that the combined effects of reduced precipitation and increased temperatures will result in negative impacts on all of the crops assessed (including beans, groundnuts, maize, millet, sorghum).

- Thereby reducing the suitable production areas as well as reducing the productivity of remaining areas.

- Pearl millet is likely to be less affected by the predicted climate changes and could be considered as an appropriate alternative staple to be promoted in areas where maize production is expected to become marginal or unsustainable, or in cases where other traditional staples such as sorghum and groundnuts are increasingly unsuitable.

- Drought-sensitive crops such as maize are likely to be increasingly unreliable or poor in yield, which will be worsened by predicted temperature increase. However, there may be inter and intra-regional differences according to the spatial distribution of rainfall ${ }^{55}$.

\subsubsection{Livestock}

- Livestock and livestock products are a big contributor to the economy of Zimbabwe, with cattle accounting for $35-38 \%$ of the GDP. It is estimated that up to $60 \%$ of rural households' own cattle, $70-90 \%$ own goats, while over $80 \%$ own chickens. The benefits of livestock for smallholder farmers have to do with food and economic security: provision of meat, milk, eggs, hides \& skins and manure. They also function as strategic household investments.

- Increased temperatures, heat stress and reduced water availability are expected to have negative impacts on livestock production. Moreover grazing systems, quality and quantity of fodder and feed will be seriously affected due to their reliance on these climatic conditions and the natural resource base. Climate change is also likely to exacerbate livestock diseases and pests.

- Small ruminants (sheep and goats) and non-ruminants (poultry) are key to women's empowerment and gender equity and are also known to be an important safety net in the event of a drought as they are easily disposable for cash when the need arises or during a drought crisis ${ }^{56} 57$.

- In terms of resilience, poultry are generally known to be relatively resilient and less sensitive to droughts. There is however evidence that climate-related stresses may directly or indirectly affect slow growth rates and poor egg production. But adaptation and genetics plays a key role as it seems that local breeds may do better than imported breeds under temperature increase and drought ${ }^{58}$.

53 World Bank. 2020. Climate Knowledge Portal Zimbabwe: https://climateknowledgeportal.worldbank.org/country/zimbabwe.

54 University of Cape Town. 2019. Climate Risk Assessment ZIMBABWE.

55 Idem.

56 FAO. 2020. Livestock production and climate change: http://www.fao.org/climate-smart-agriculture-sourcebook.

7 IFAD - COSOP. 2020. Republic of Zimbabwe Country Strategic Opportunities Programme 2020 - 2025.

58 N. M. B. Nyoni, S. Grab \& E. R. M. Archer, 2018. 'Heat stress and chickens: climate risk effects on rural poultry farming in low-income countries'. and Development, 11:1, 83-90, DOI: 10.1080/17565529.2018.1442792. 
- In terms of mitigation, livestock food chains are major contributors to greenhouse gas emissions; with cattle having the largest footprint and poultry being one of the 'greenest' meats, using up less resources and emitting less ${ }^{59}$.

\subsubsection{Post-harvest food loss}

- Post-harvest food loss in Sub-Saharan Africa (SSA) represents a multi-faceted challenge that reduces the income of approximately 470 million farmers and other value chain actors by as much as $15 \%$ (The Rockefeller Foundation 2013). Projected climate change impacts for Zimbabwe, characterised by reduced rainfall, higher temperatures and increased frequency and severity of dry spells, will result in substantial yield reductions making it imperative to eliminate all avoidable preto post-harvest crop yield losses. For some of the climate-smart and nutrition-sensitive crops like small grains (e.g. sorghum, millets) bird damage before harvesting can be as high as $100 \%$ if harvesting is delayed. Post-harvest handling of such crops (e.g. threshing, dehulling) is labourintensive and largely done by women making the provision of appropriate harvesting and postharvest handling equipment necessary for smallholder farmers to embrace such value chains. In horticulture, poor market information and arrangements results in a large proportion of the produce going bad during food distribution as smallholder farmers flood the market with the same product.

- This is supported by a recent CCAFs study which shows the highest levels of food loss \& waste (FLW) for SSA can be found in primary production, storage $\&$ handling and the food distribution. The FLW of Roots and Tubers for SSA was significant in the primary production, storage and handling stages, which requires special attention from policymakers.

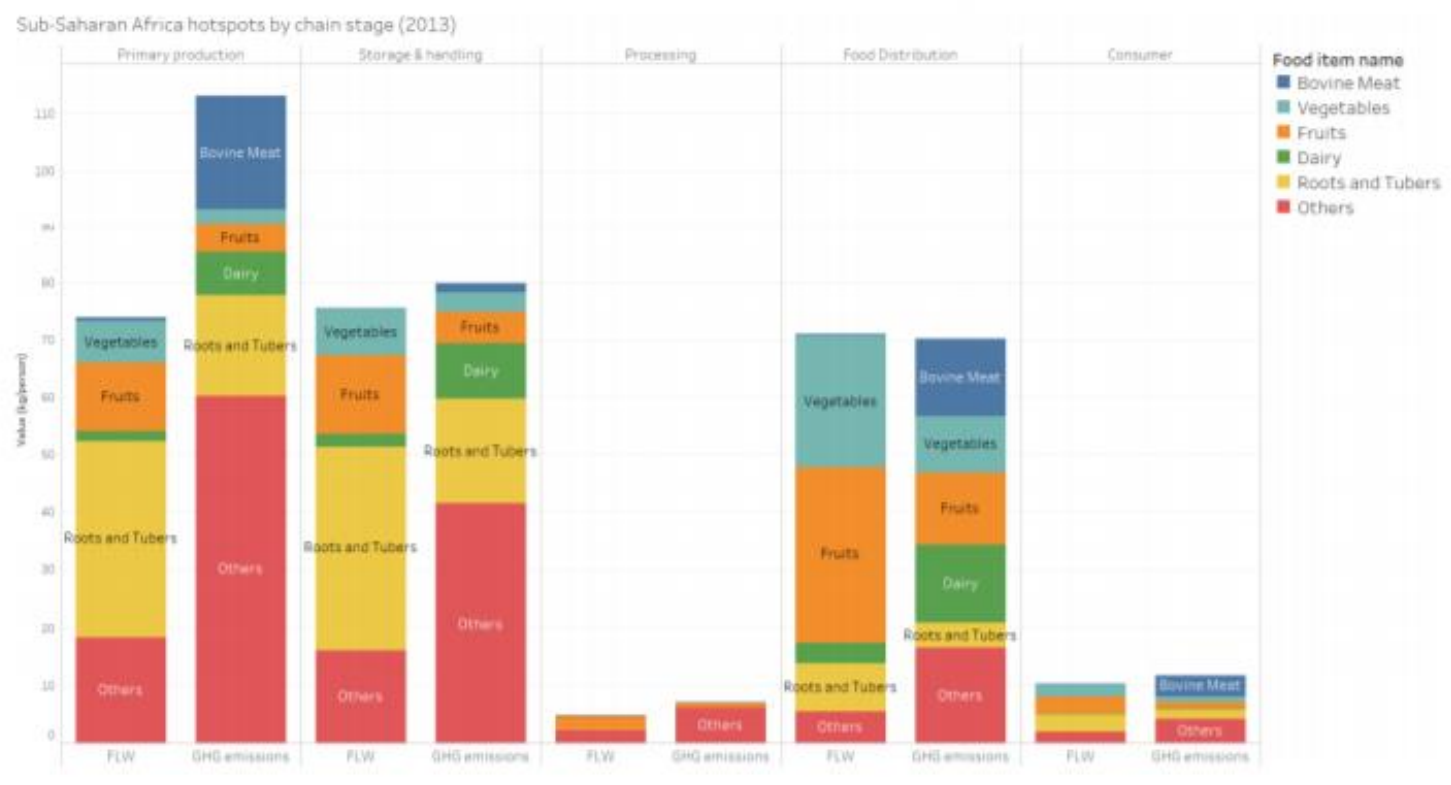

Figure 15 The Food Loss and Waste (FLW) and associated GHG emissions overview for SubSaharan Africa by value chain stage ${ }^{60}$.

\subsection{Climate Vulnerable Groups}

Climate change vulnerability refers to the degree to which a system or specific groups are sensitive to and unable to cope with negative effects caused by climate change. The vulnerability can be reduced by strengthening the adaptive capacity (AC) of those vulnerable groups. This entails the ability of a system or actors to adapts to climate change (including climate variability and extremes) to minimise

59 FAO. 2020. Livestock production and climate change: http://www.fao.org/climate-smart-agriculture-sourcebook.

60 CCAFs. 2019. Working paper: A global hotspot analysis on food loss \& waste and associated greenhouse gas emissions. 
potential damages, to take advantage of opportunities and/or or to cope with the consequences ${ }^{61}$. Important factors shaping the adaptive capacity is their access to and control over natural, human, social, physical and financial resources.

As the majority of smallholder farmers in Zimbabwe have low income, limited access to resources and rely on rain-fed subsistence agriculture, their adaptive capacity is not that high. The previous chapter on nutrition situation analysis highlighted that the rate of undernourishment in Zimbabwe stands at $51 \%$, people's health and nutritional status also affects their adaptive capacity to the consequences of climate change. One can look in more detail at common indicators that help to assess the AC of these for agricultural households. Such an assessment can help identify capacity gaps and opportunities.

- Education: \% literacy rate; participation in (vocational) training, extension support.

- Access to agricultural information: households with mobile phones.

- Access to agricultural inputs, drought-resistant seeds.

- Access to finance and loans.

- Adoption of improved agricultural practices: investment in irrigation, land improvement and conservation.

- Institutions: policies and regulations may constrain or enhance adaptive capacity.

No thorough vulnerability assessment for specific target groups has been carried out, but based on various interviews with key informants and literature reviews, the following groups have been identified as vulnerable to climate change impacts:

- Smallholder farmers - in general:

- About $76 \%$ of the rural households are poor compared to $38.2 \%$ of urban households. It is often these poor rural households which are more vulnerable and affected by climate change because of their weak coping mechanisms.

- Due to dependence on rain-fed irrigation systems which are highly sensitive to droughts, low and erratic rainfall and other extreme weather events which lead to low and declining soil fertility.

- Low investment in agriculture, shortages of farm power - labour and draft animals, poor physical and institutional infrastructure, poverty and recurring food insecurity.

- Regions: Smallholder farmers in Mashonaland West, Midlands and Mashonaland Central have the highest overall capacities to respond to climate change impacts (ranking 1st, 2nd, and 3rd, respectively. Masvingo, Matabeleland North and South have the lowest overall adaptive capacity (ranking 6th, 7th and 8th - see also Figure 19 and would be least able to respond or adapt to climate change-related impacts ${ }^{62}$.

\section{- Former farm workers:}

- Many former farmer workers still live on the former commercial farm compounds and have very limited access to land.

- The former farm workers have valuable hands-on commercial experience in some crop value chains from their previous employment.

- Majority of them do not have access to land or other resources required for farming, are generally less educated compared to other SHFs.

- Women: are more vulnerable to climate change impacts than men which has to do with underlying existing power relations, structures, gender inequalities. Rural women who are already placed in a disadvantageous place, will also have a lower adaptive capacity ${ }^{63}$ :

- Lack of ownership in land (due to land allocation, inheritance), livestock, other technologies, assets which could increase their adaptive capacity.

- Limited or no access to (climate) finance, loans which could harness new technologies for farming under climatic conditions.

- Men have more assets, more access to finance which they are able to harness, while women may not have these opportunities.

- Women may also have an increased workload due to fetching water (further distances/amount), have to do more farm and housework.

- Less opportunities for women compared to men to attend training/extension services in relation to climate information, awareness raising on the importance and effects of climate change and

61 IPCC. 2007. Fourth Assessment Report.

62 IFAD - COSOP. 2020. Republic of Zimbabwe Country Strategic Opportunities Programme 2020 - 2025

63 Interview with Dr. Sandra Bhatasara - University of Zimbabwe. 
knowledge gaps regarding climate-resilient agriculture/technologies. When women are invited they first have to seek permission or negotiate to participate in capacity building activities.

- Limited participation in decision-making at $\mathrm{HH}$ and community level.

- Other vulnerable groups: children, especially orphans, elderly and people with disabilities, living with HIV and chronic diseases.

- Due to a lack of land, assets, finance or ability to work, these groups often have very limited resources to buttress themselves against climate change-related stresses.

- In the areas in the southern border with Botswana and South Africa, elderly tend to be even more vulnerable due to migration of their children to neighbouring countries for employment opportunities leaving their parents alone without a social safety net.

- Youth are not as vulnerable as the other groups mentioned above as they are flexible: can easily move, migrate, change livelihoods which increases their AC. However, they often do not have access to land, assets or finance. A contributing factor making urban and rural youth more financially insecure as the high unemployment rate among youth in Zimbabwe is estimated to be at least $84 \%$ of the unemployed ${ }^{64} 65$.

\section{$5.4 \quad$ Spatial vulnerability}

Zimbabwe is administratively divided into 10 provinces (two of which are cities with provincial status) and geographically divided into 6 agro-ecological regions.

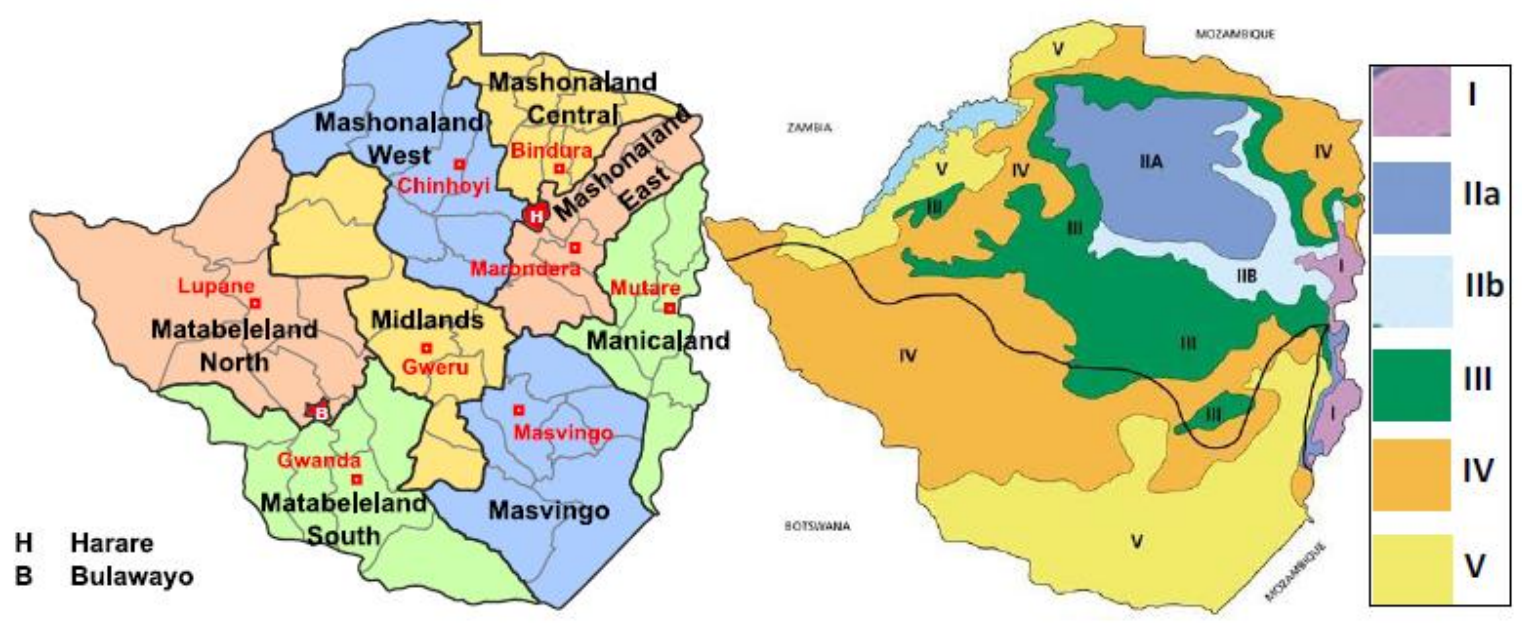

Figure 16 Map of Zimbabwe's provinces and agro-ecological regions ${ }^{66}$.

Climate change has province-specific impacts, which requires a careful analysis before prioritising key intervention areas and formulating value chains interventions. Specific adaptation and mitigation measures might be effective in one province, but not in the others or even contribute to maladaptation. This section summarises outcomes related to spatial vulnerability in 1) the current and future climate impacts per province and 2) the current level of adaptive capacity of SHF per province; to what extent are people able to adapt and cope with these projected changes.

\section{1). The current and future potential impacts of climate-related hazards per province}

- According to the Agriculture Sector Disaster Risk Assessment by the World Bank ${ }^{67}$ The most $^{2}$ important agricultural risk in Zimbabwe is drought and will further impact agricultural production

\footnotetext{
Interview with Clophas Ncube - FAO Green Jobs for Youths Project.

65 IFAD - COSOP. 2020. Republic of Zimbabwe Country Strategic Opportunities Programme 2020 - 2025.

66 University of Cape Town. 2019. Climate Risk Assessment ZIMBABWE.

67 World Bank, 2019. Zimbabwe: Agriculture Sector Disaster Risk Assessment.
} 
and food security. Temperature increase and changes in precipitation will increase the frequency and severity of drought.

- This is supported by a recent spatial study on drought risk to Agricultural Systems in Zimbabwe by Frischen ${ }^{68}$. Drought risk refers to the likelihood to suffer damages and economic losses during or after a drought. Figure 17 shows the spatial differentiation (2013-2018) between rain-fed agricultural systems, which represent the largest share in the country, compared to irrigated systems. Frischen concludes that every district of Zimbabwe has been affected by drought, but the south-western provinces Matabeleland North and Matabeleland South in particular. Generally speaking Mashonaland East has been less affected by drought (Figure 18).

- Regarding irrigated agricultural systems, the highest drought risk is observed in Chipinge.

- Regarding rain-fed agriculture, the highest drought risk occurs in multiple districts, including Buhera (Manicaland), Mount Darwin (Mashonaland Central), Gokwe South (Midlands), Beitbridge, Gwanda, Matobe, and Mangwe (Matabeleland South).

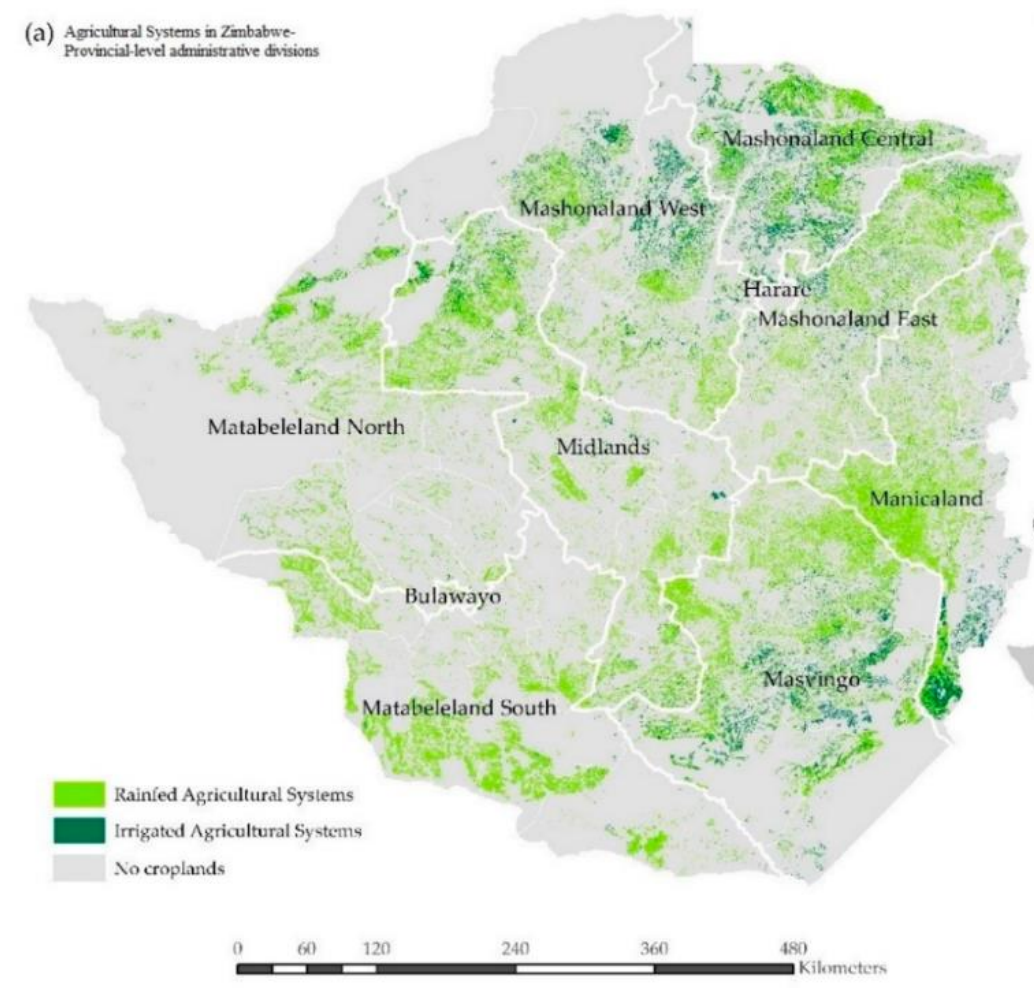

(b) location of ambabwe in affica

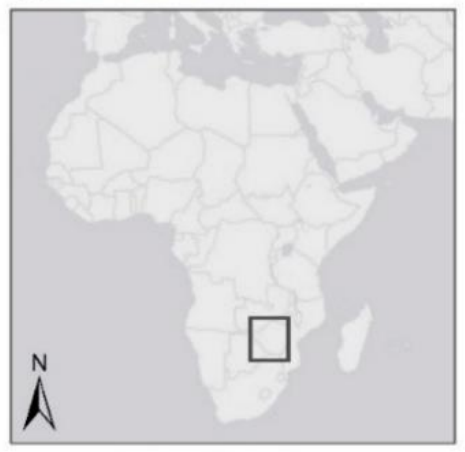

(c)

Administrative Map

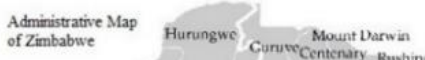

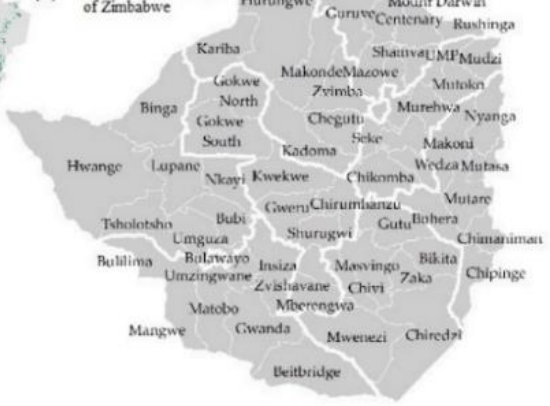

Figure 17 Agricultural Systems in Zimbabwe: Differentiation between rain-fed and irrigated agriculture $^{69}$.

68 Janna Frischen, Isabel Meza, Daniel Rupp, Katharina Wietler and Michael Hagenlocher, 2020. Drought Risk to Agricultural Systems in Zimbabwe: A Spatial Analysis of Hazard, Exposure and Vulnerability. Sustainability 2020, 12, 752; doi:10.3390/su12030752. Idem. 

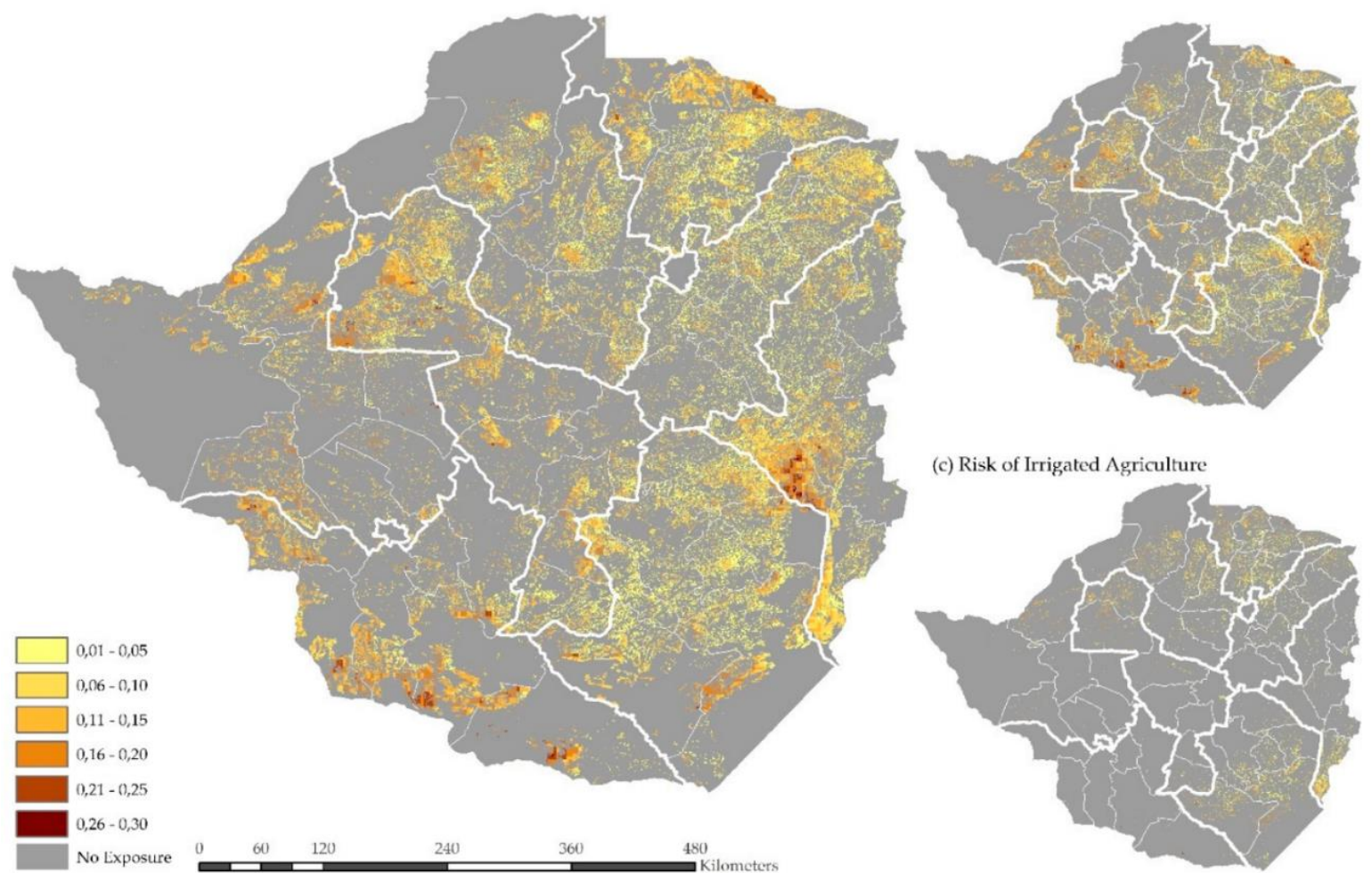

(c) Risk of Irrigated Agriculture

Figure 18 Drought risk to rain-fed and irrigated agriculture considering drought frequency ${ }^{70}$.

\section{2). The current adaptive capacity of smallholder farmers per province:}

- Smallholder farmers in Mashonaland West and the Midlands have the highest overall capacities to respond to climate change's impacts (ranking 1 st and 2 nd).

- Matabeleland North and South have the lowest overall adaptive capacity scores (ranking 7th and 8th) and therefore are expected to be least able to respond or adapt to climate change-related impacts.

\begin{tabular}{|c|c|c|c|c|c|c|c|c|}
\hline Adaptive capacity Indicator category & Manicaland & \begin{tabular}{|l|} 
Mashonaland \\
Central
\end{tabular} & Mashonaland East & \begin{tabular}{|l|}
$\begin{array}{l}\text { Mashonaland } \\
\text { West }\end{array}$ \\
\end{tabular} & Masvingo & \begin{tabular}{|l|} 
Matabeleland \\
North \\
\end{tabular} & \begin{tabular}{|l|}
$\begin{array}{l}\text { Matabeleland } \\
\text { South }\end{array}$ \\
\end{tabular} & Midlands \\
\hline Adoption of improved agricultural practices & 0.41 & 0.72 & 0.54 & 1.00 & 0.50 & 0.25 & 0.09 & 0.66 \\
\hline Access to agricultural information & 1.00 & 0.60 & 0.76 & 0.73 & 0.81 & 0.32 & 0.36 & 0.77 \\
\hline Education & 0.99 & 0.96 & 0.99 & 0.98 & 0.98 & 0.96 & 1.00 & 1.00 \\
\hline Adaptive capacity score & 0.76 & 0.81 & 0.76 & 1.00 & 0.75 & 0.48 & 0.42 & 0.83 \\
\hline Adaptive capacity rank & 5 & 3 & 4 & 1 & 6 & 7 & 8 & 2 \\
\hline
\end{tabular}

Figure 19 Adaptive Capacity of SHF for each province of Zimbabwe ${ }^{71}$.

To conclude, when we look at drought risk (likelihood to suffer damages and economic losses during or after drought), for rain-fed agriculture, the following 4 provinces have the highest risk (green circles):

- Manicaland

- Mashonaland Central

- Midlands

- Matabeleland South

When we look at the adaptive capacity (the ability of SHF for each province to adjust to climate change) of all farming systems per province, the following 2 provinces can be considered highly vulnerable to climate change (red circles):

- Matabeleland North

- Matabeleland South

70 Idem.

71 University of Cape Town. 2019. Climate Risk Assessment ZIMBABWE. 


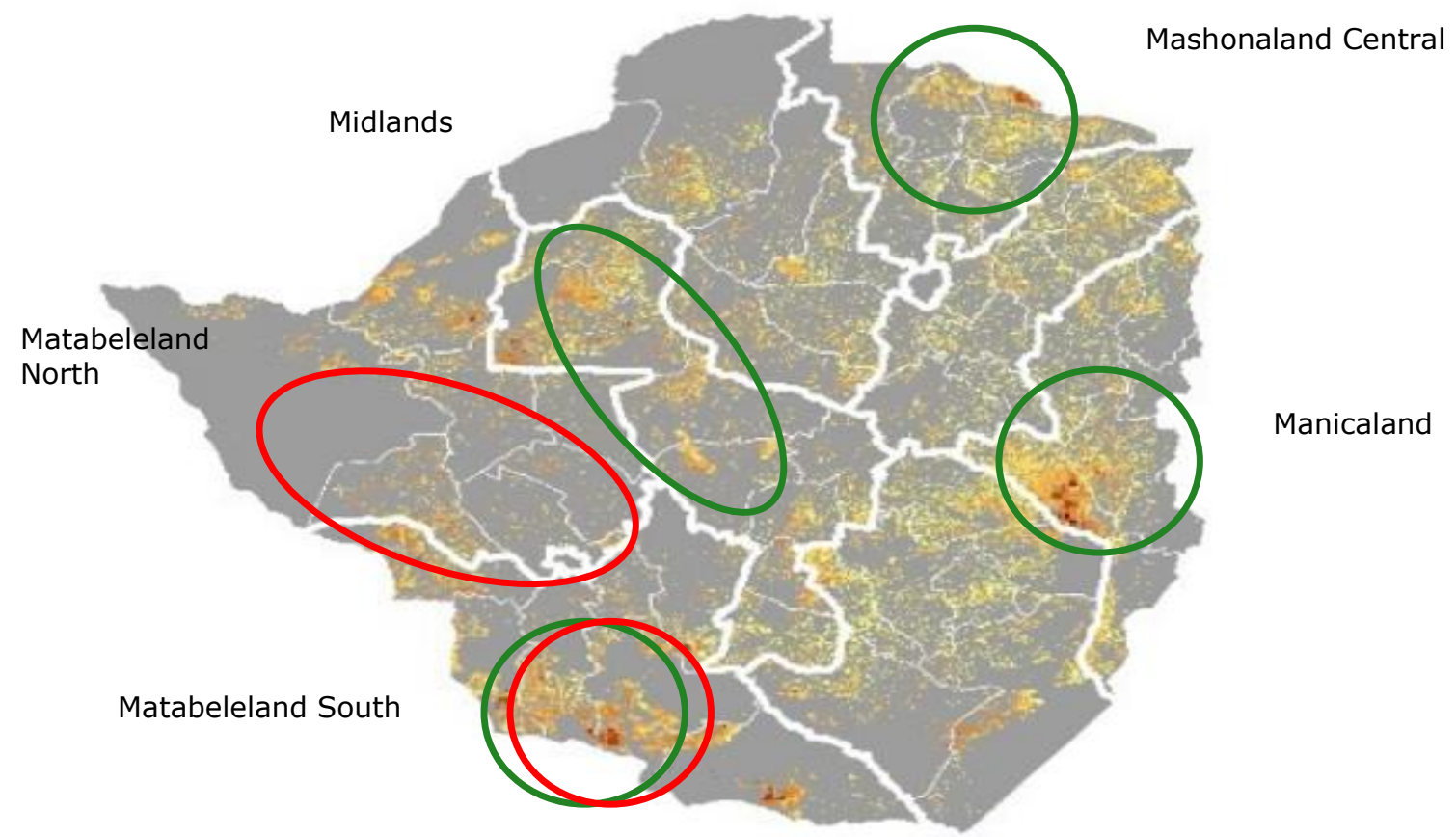

Figure 20 Most vulnerable provinces according to drought risk to rain-fed agriculture (green) and adaptive capacity (red).

\subsection{Early Warning Systems}

Early warning systems (EWS) are an essential element of disaster risk reduction. Proper development and implementation can enormously reduce the (climate) vulnerability of SHFs in Zimbabwe.

According to the UNDRR and the Zimbabwean Meteorological Services Department (MSD), the effectiveness of these ESW is determined by the active involvement of communities at risk to ensure there is a constant state of preparedness at various policy levels. This implies that these systems warn (remote) communities in time and the messages are understandable to those at risk. These type of early warning systems are therefore referred to as People-Centred Early Warning Systems. The UNDRR (formerly known as UNISDR) ${ }^{72}$ describe these as early warning systems aimed to empower individuals and communities threatened by hazards to act in time and in an appropriate manner to reduce potential damages and losses. Four interrelated elements of such an effective early warning system have been identified (see Figure 21):

1. Risk knowledge: climate data collection and vulnerability/risks assessments

2. Monitoring and warning service

3. Dissemination \& communication

4. Building response capability

The full description and practical checklist for developing early warning systems can be found in the link of UNDRR below. These are useful documents for the development of (people-centred) early warning systems:

$\checkmark$ UNDP - Early Warning Systems, 2018 https://www.undrr.org/publication/early-warning-practicescan-save-lives-selected-examples

$\checkmark$ UNDRR - Developing Early Warning Systems: A Checklist, 2006

https://www.unisdr.org/files/608_10340.pdf

$\checkmark$ UNESCO - Zimbabwe Flood and Drought Monitor https://en.unesco.org/news/unesco-launchzimbabwe-flood-and-drought-monitor

72 UN Office for Disaster Risk Reduction. 


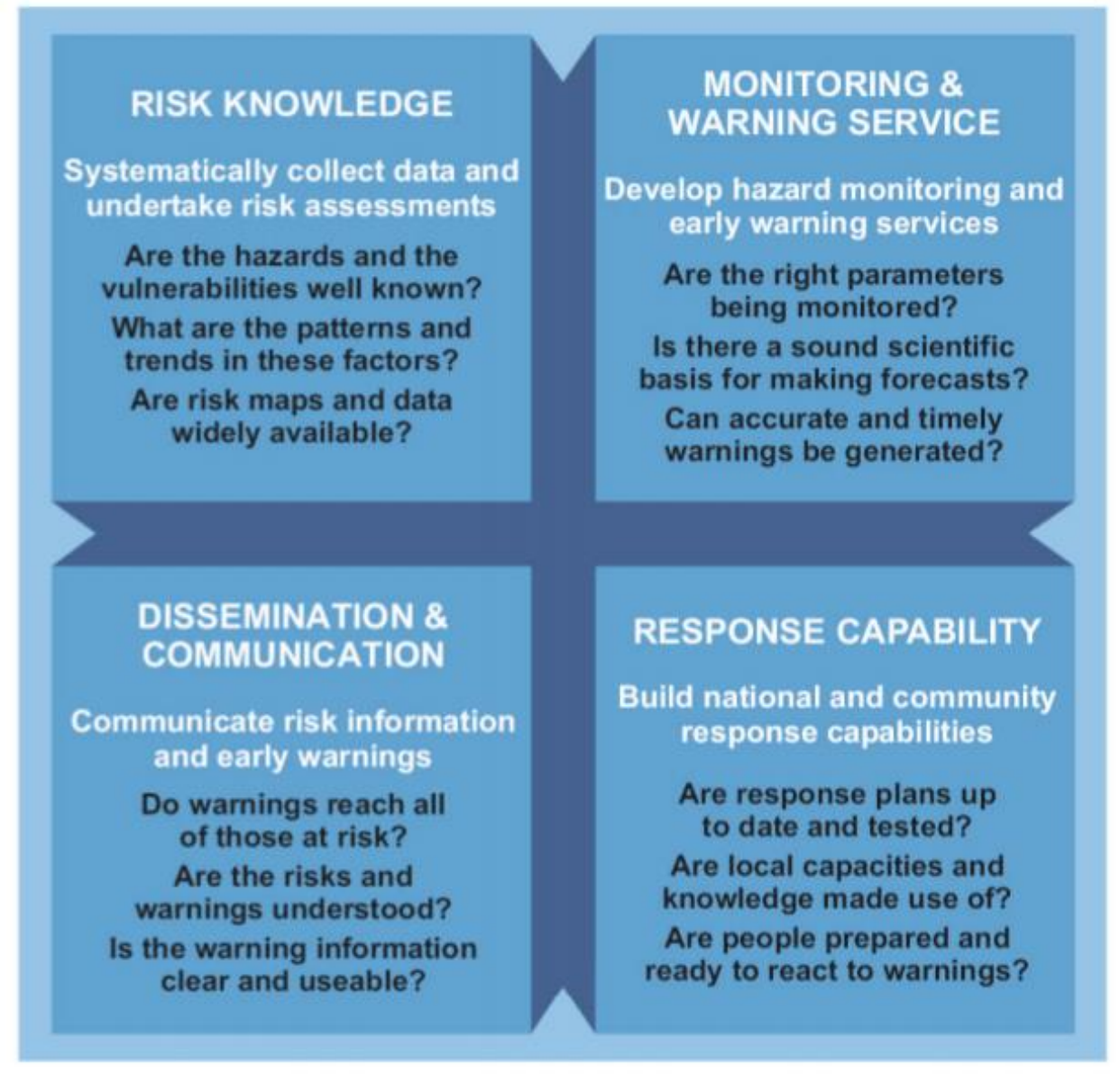

Figure 21 Four Elements of People-centred Early Warning Systems ${ }^{73}$.

EWS challenges in Zimbabwe:

The following challenges hamper effective development and implementation of early warning systems in Zimbabwe:

- Lack of adequate ITC infrastructure ${ }^{74}$

- Poor funding and investments in EWS

- Perceptions of government bodies and local communities: through becoming accustomed to the predictions over the years of El-Nino droughts and floods, the warnings have been perceived as false alarms and thus ignored.

- EWS communication:

- The current EWS communication is one-way: those issuing warnings are not fully aware of the needs and priorities of the vulnerable communities, and therefore not responsive to their needs ${ }^{75}$.

- The information is poorly disseminated to communities with low levels of adaptive capacity.

- Limited adaptive capacity of poor communities and absence of preparedness plans for possible evacuation.

\section{Meteorological agencies for Zimbabwe:}

$\checkmark$ Meteorological Services Department (MSD - Zimbabwe) ${ }^{76}$

- Role of MSD in EWS:

- Risk identification (observation \& monitoring, hazard analysis)

- Risk reduction (hazard forecasts, early warnings)

\footnotetext{
73 UN Office for Disaster Risk Reduction.

74 The Herald, 2019 Early warning systems vital for disaster risk preparedness | The Herald 29 NOV.

75 Gwimbi, P. 2007 the effectiveness of early warning systems for the reduction of flood disasters: some experiences from cyclone induced floods in Zimbabwe. Journal of Sustainable Development in Africa (Volume 9, No.4, 2007).

76 MSD - http://www.msd.org.zw/.
} 
- Risk transfer: (provision of historical and real-time data and analysis to support catastrophe insurance).

$\checkmark$ Global Agricultural Geo-monitoring Initiative (GEOGLAM - International)

- Role of GEOGLAM in EWS: GEOGLAM initiated by the G20 - Agriculture Ministers during the French G20 Presidency in 2011. The mandate has expanded to include food security concerns and to support early warning for international agency response to emerging food emergencies.

\subsection{Policy Arena Climate Change}

Key policy documents for climate change are Zimbabwe's National Climate Change Response Strategy (2016), Zimbabwe Climate Policy (2016), Nationally Determined Contributions (NDCs), National Drought Plan for Zimbabwe and Climate Smart Agriculture Profile of Zimbabwe ${ }^{77}$.

The National Climate Response Strategy (2016) recognises the impact of climate on food and nutrition security: 'Zimbabwe faces a dilemma on how to balance the short-term food needs and long-term production goals of the different farmer communities because of climate-induced crop failures... Food shortages have become a perennial feature resulting in a high prevalence of undernourishment estimated at 30 to 54 per cent between 2006 and 2012....communities have very limited choices to satisfy their food preferences, neither do they have a say about the quality of food they eat, raising critical concerns about food safety. During periods of climate-induced disasters (e.g. droughts and floods), the basic systems that ensure access, proper handling, preparation and storage of food are often severely compromised, leading to frequent outbreaks of food-borne illnesses. Increasing climate pressures will also inevitably lead to rising food prices weighing heavily on household and national budgets. Disadvantaged social groups will therefore be condemned deeper into hunger and malnutrition.'

The National Climate Response Strategy addresses the need 'to focus more on community empowerment processes that enable collective action towards increased production, risk management and enhanced market participation to improve their adaptation to climate change'. With this strategy, they plan for concrete on climate - nutritional linkages: 1) Strengthen capacity of local, provincial and national institutions to work with communities in developing mechanisms for enhancing local social safety nets around food security and natural resources, 2) Develop training programmes for promoting processing and consumption of neglected but stress tolerant and nutritious crops, 3) Strengthen capacity for development of new food recipes and industrial products using stress tolerant and traditional crops.

Key institutions for climate change: Meteorological Services Department (MSD - Zimbabwe) Ministry of Lands, Agriculture, Water, Climate and Rural Resettlement; Ministry of Energy and Power Development; Climate Unit; Zimbabwe National Water Authority, UNDP, FAO, ICRISAT, CIAT, The Infrastructure Development Bank of Zimbabwe (IDBZ).

Ongoing or recent Climate Projects in Zimbabwe (preliminary list):

- FAO green jobs for youth (2019 - ongoing)

- Scaling up Adaptation in Zimbabwe, through Strengthening Integrated Planning Systems (UNDP) (2014-2018)

- Supporting the Implementation of Zimbabwe's Nationally Determined Contributions under the Paris Agreement on Climate Change (UNDP) (2018-2020)

- Green Climate Fund - Supporting the long-term adaptation of vulnerable and food-insecure Zimbabwean households (2019-2023)

77 Developed by World Bank, CGIAR Research Program on Climate Change, Agriculture and Food Security, International Center for Tropical Agriculture. 


\section{Potential pathways}

This chapter will describe the pathways to climate, nutrition, youth and gender outcomes that have been identified for SACP, based on the pre-design study findings. These pathways have been developed by using a food systems approach described in section 1.5. Each pathway therefore uses the logic of food systems thinking and illustrate how potential interventions can contribute to nutrition and reduced climate vulnerability outcomes. The following pathways have been identified:

1. Improved income for dietary improvements

2. Selection of value chains

- Edible insects

- Indigenous vegetables

- Biofortified crops

3. Strengthen value chain linkages

4. Women's empowerment

5. Youth inclusion in agriculture value chain development

6. Capacity on nutrition and climate of agricultural extension workers

7. Reduce post-harvest losses

Figure 22 depicts the adapted food systems frameworks and shows with coloured arrows (see the corresponding pathways on the rights). Ultimately, all pathways contribute to food system outcomes (purple box), however all through various food system dynamics. The following sections will describe each pathway in more detail.

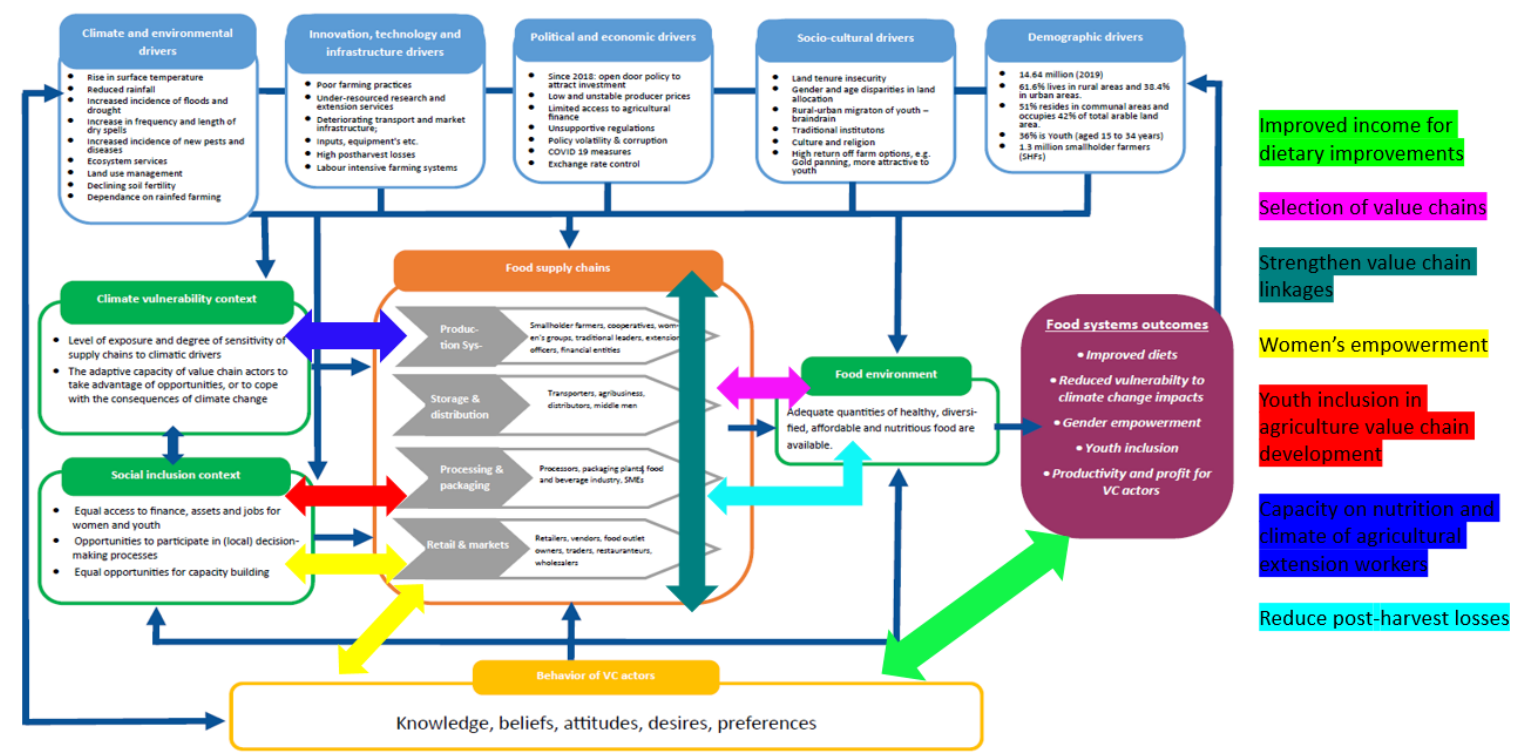

Figure 22 Adapted Food Systems Framework including entry points for proposed pathways. 


\subsection{Improved income}

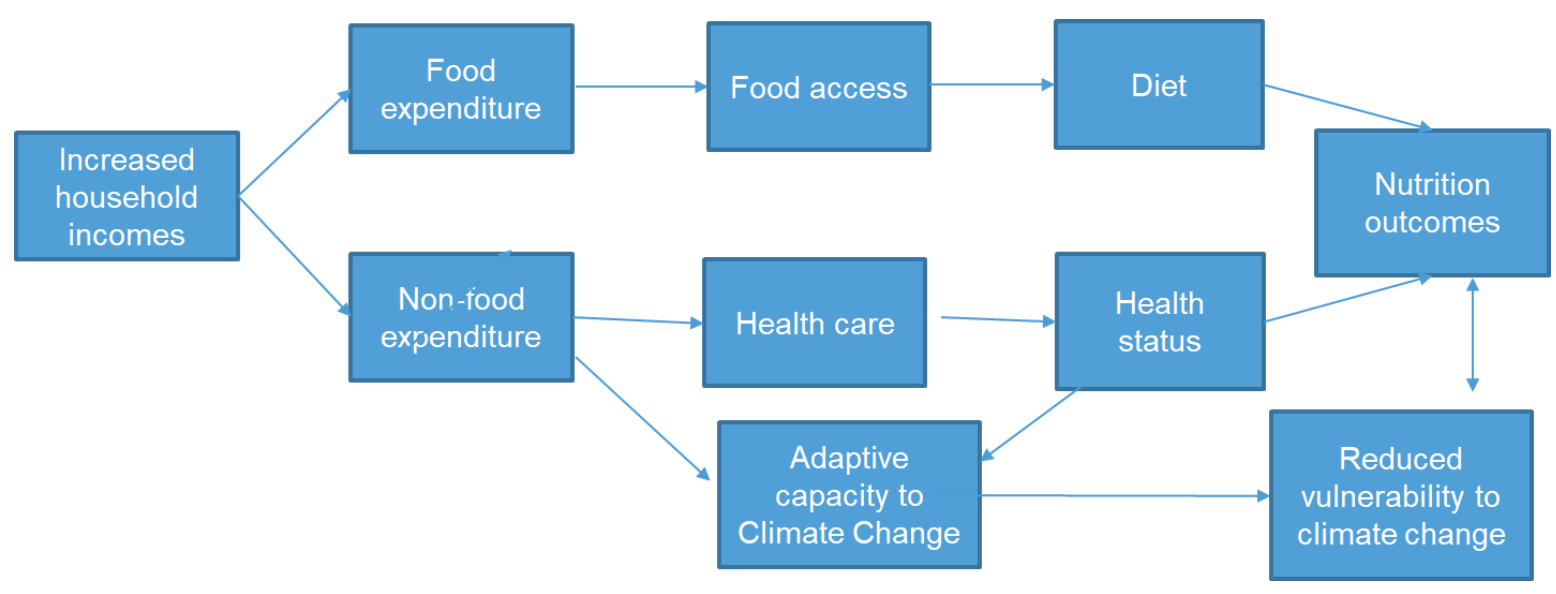

The majority of smallholder farmers in Zimbabwe have low incomes, which limits their adaptive capacity to climate change and access to food. In SACP, the envisioned results aim to increase marketed agricultural output and, as a result, beneficiary income. In principle, the increase in income could lead to dietary improvements in the household by enabling the purchase of more nutritious and diverse foods, as well as improving access to healthcare, women's economic empowerment, better water and sanitation, and better education. However, evidence shows that dietary and other improvements do not happen automatically with increases in income. In fact, there are a number of factors, especially low nutrition awareness and women's social status, that can prevent increases in income from leading to improvements in nutrition. Research shows that income generation is essential, but not sufficient, to improve nutrition outcomes-in fact, it can have a positive, negative, or neutral effect on nutrition for beneficiaries or clients of agricultural projects ${ }^{78}$. The income pathway, as one of the primary pathways for improving nutrition through agriculture, has been studied and documented by USAID's SPRING project: 'Income may affect nutrition both in how money is earned as well as in how it is spent. For example, devoting additional time to work-related activities could negatively affect breastfeeding, timely provision of complementary foods, or other childcare responsibilities among women if activities do not also foster more equitable balances of care responsibilities, or promote opportunities that allow both men and women flexibility in how they earn income and invest in nutrition. Smallholder farmers must also balance decisions between how much of their land to dedicate to cash crops and how much to set aside to grow food for family consumption, as cash is needed for non-food expenditures as well as for purchasing other foods that it may not be practical to grow $^{\prime 79}$. Therefore, to ensure that an increase in income leads to improvements in nutrition, it is fundamental to complement any income-generation activities with specific actions to raise the target population's nutrition awareness and stimulate its consumption of nutritious foods and, most likely, increase the empowerment of women as well. Awareness raising should evolve around the following:

- Using income and/or savings to cover the costs of health care, food or childcare can make the difference between seasonal illness or weight loss for women and children and year-round health for all.

- Spending income to purchase, prepare, and consume diverse nutrient-rich foods will also contribute to nutrition outcomes.

- The negative consequences of consuming cheap, unsafe, and unhealthy foods (highly processed, high in fat, sugar and salt).

In other programmes, care groups have been reported to be a suitable vehicle to convey messages to raise awareness on nutrition. Interpersonal behaviour change communication strategies, including role play and composition of songs and skits is often used to disseminate messages. A care group is a group of $10-15$ volunteer community-based health educators. Each volunteer, known as a care group

78 World Bank. 2007. From Agriculture to Nutrition: Pathways, Synergies and Outcomes.

79 https://www.usaid.gov/global-health/health-areas/nutrition/technical-areas/nutrition-sensitive-agriculture-applyingincome. 
volunteer, is responsible for about 10 - 15 mothers (pregnant women and mothers of young children, usually 0-59 months of age or 0-23 months of age). This volunteer is commonly appointed by the mothers themselves; occasionally community leaders participate in the selection process.

Supervisory field staff are recruited and trained to set up care groups in collaboration with community leaders so that: (1) Care group volunteers are appointed and active in their role, and (2) all pregnant women and mothers of young children are linked to a care group volunteer. The care group frequently meets with project staff for training and supervision.

The care groups models has been used in the FAO implemented nutrition-sensitive agriculture programme in Zimbabwe; the Livelihoods and Food Security Programme (LFSP). The impact of the care group approach on adoption of positive nutrition behaviours, practices and nutrition outcomes has been recently evaluated. It was found that age, family composition and livelihood source of the household are related to household participation in care group support. Secondly, care group support participation positively impacts household knowledge, growth and consumption of biofortified foods. Finally, the household participation in care group support positively impacts knowledge and practices of nutrition behaviours as well as child nutrition ${ }^{80}$.

Through the use of volunteers at the household level, rather than paid promoters, the care group model presents a low-cost approach for programme delivery, as it has a multiplier effect reaching to an increased number of the target population.

\subsection{Investment in resilient value chains with nutrition value}

A nutrition-sensitive approach considers how development of food value chains could contribute to improving nutrition. For the selection of a specific value chain, one should identify the main nutrition problems in the target population, and its relation to food consumption patterns. Specific food commodities can then be identified as having potential to address these nutrition problems, particularly if one considers multiple commodities that can contribute to a healthier diet and, when taken as a whole, creation of a more nutrition-sensitive food system. Once the potential foods have been selected, their respective value chains can be analysed to identify constraints that could be addressed by the project and include climate, gender and youth considerations.

The ZimVac report concluded that dietary diversity among rural consumers is lower than among the urban population. The consumption of protein-rich foods such as beans and legumes, and animal source foods was found to be inadequate. This study recommends to invest in a variety of climatesmart value chains, to contribute to the availability of safe, affordable and nutritious foods - especially for the under consumed food groups: fruits, vegetables, protein-rich foods, and iron-rich foods.

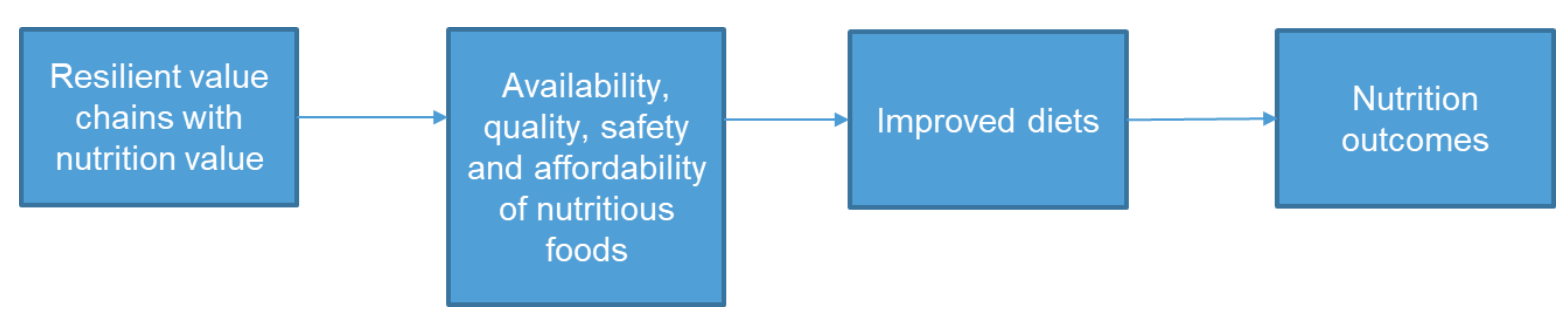

The selection of the value chains will, to a large extent, determine if the project will be successful on climate and nutrition-related outcomes. The study mission team has compiled a list of the value chains that came up during the stakeholder interviews, or were included in a recently released note by the

80 Macheka, L. et al., Impact of care group participation on household nutrition behaviours, practices and nutrition outcomes in rural Zimbabwe. 
government of Zimbabwe on priority value chains. This list was then incorporated into a matrix to add nutrition considerations as well as Zimbabwe-specific youth, gender, and climate considerations in these value chains based on secondary sources and key informants (see Annex 4). The value chain analysis, planned under component 1 of SACP can build on this overview.

\section{Scoring value chains}

Value chains highlighted in green are recommend as investing in those value chains expected to contribute to (i) improved nutrition as the respective foods help fill the dietary gaps in Zimbabwe AND (ii) positive outcomes in at least one of the other mainstream areas: climate resilience, female empowerment or employment opportunities for youth.

Value chains highlighted in orange are interesting as they may provide opportunities for youth inclusion, gender empowerment or building resilience to climate change, but are not likely to contribute to filling dietary gaps in Zimbabwe.

Value chains highlighted in red are discouraged, as they may lead to negative or unwanted results in the outcome areas for climate, gender, nutrition and/or youth. The matrix is not yet exhaustive, it is recommended to update the scoring and colour coding once the matrix is further completed.

Three value chains highlighted below seemed to stand out when it comes to co-benefit climate and nutrition:

\section{Edible insects}

Recent studies ${ }^{81,82,83,84}$ conducted in Zimbabwe have shown that edible insects have great potential to contribute toward nutrition security and livelihoods in both urban and rural areas in Zimbabwe. In 2012, FAO identified edible insects as sustainable alternatives to close the anticipated food deficit gap, particularly protein, as insects are highly nutritious and have a low carbon footprint ${ }^{85}$. Insects are rich in protein (range between $52-70 \%$ ) and micronutrients (iron: $24.2-52.9 \mathrm{mg} / 100 \mathrm{~g}$ ) and zinc content: $10.0-20.9 \mathrm{mg} / 100 \mathrm{~g})^{64}$ with intervention studies showing that their consumption improves nutrition. Insect consumption is a common practice among rural and urban Zimbabweans ${ }^{62,65}$. More so, edible insects such as mopane worms (Imbrasia belina) have been identified by ILO Zimbabwe to have great potential for women's economic empowerment venture ${ }^{86}$. The high acceptance and consumption of edible insects in both rural and urban areas present a great opportunity to promote and develop the edible insect value chain. Edible insects are an excellent opportunity as they are prevalent in the most arid parts of Zimbabwe where households are vulnerable to food insecurity and nutrition. For example, the mopane tree (of which edible mopane worm can be harvested) grows in degraded soils not suitable for cropping and therefore there won't be any competition with other crops but instead can contribute to climate change mitigation if propagated in other areas as a way of increasing the geographical spread of the mopane worms. In addition, the edible insect value is already popular with women and youth who dominate the harvesting, processing and informal marketing (e.g. roadside marketing) of the processed insects, hence this value chain has great potential to contribute towards household income and the empowerment of women and youths.

81 Manditsera et al. (2018). Consumption patterns of edible insects in rural and urban areas of Zimbabwe: taste, nutritional value and availability are key elements for keeping the insect eating habit. Food Sec. 10, 561-570 (2018). https://doi.org/10.1007/s12571-018-0801-8.

82 Manditsera et al. (2019). The contribution of wild harvested edible insects (Eulepida mashona and Henicus whellani) to nutrition security in Zimbabwe. Journal of Food Composition and Analysis, 75, 17-25.

83 Manditsera, F. A. (2019). Wild harvested edible insects: potential for nutrition security. Wageningen: Wageningen University. https://doi.org/10.18174/496746.

84 Musundire et al. (2014). Nutrient and anti-nutrient composition of Henicus whellani (Orthoptera: Stenopelmatidae), an edible ground cricket, in south-eastern Zimbabwe. Int J Trop Insect Sci 34, 223-231 (2014). https://doi.org/10.1017/S1742758414000484.

85 http://www.fao.org/3/i3253e/i3253e.pdf.

86 https://www.ilo.org/africa/countries-covered/zimbabwe/WCMS_626769/lang--en/index.htm. 
Investing in the value chain of edible insects should include (but not be limited to):

- There is an urgent need to regulate and control the harvesting practices to prevent overharvesting and negative environmental impacts (e.g. this can be done through issuing harvesting permits). For example, over exploitation (overharvesting) and lack of control of the mopane caterpillar is a threat to this value chain. Several studies have recommended proper governance structure and control of natural resources such as edible insects for these value chains to be sustainable.

- Train communities on sustainable harvesting and processing practices (Good Harvesting practices and Good Hygienic and Processing Practices.

- Built capacity on processing and storage facilities.

- Build capacity on domestication of the edible insects, especially mopane worms, crickets and black soldier fly (for animal feed).

- Propagation of mopane trees in order to increase the geographical availability of the worms thereby reducing possible environmental damage during harvesting in smaller areas.

According to the informants, there is a ready market for edible insects, it is a 'self-promoting food', categorised as organic, so the initial focus could be on increasing the supply of edible insects. The value chain interventions should aim to increase the year-round availability of edible insects on the local markets which are safely handled. This can improve dietary diversity and quality, and increase protein and micronutrient intake.

Suggested partners: The Marondera University of Agricultural Sciences \& Technology (MUAST) is working with a $£ 913,287$ grant on the promotion of the mopane worms for food and nutrition security; Upscaling edible insect-based porridge to improve health and nutritional status of Primary School children in Zimbabwe's low socio-economic communities (funded by BBSRC/UKRI)

Indigenous vegetables

The dependency of African rural households on indigenous vegetables for sustenance has been widely acknowledged and cannot be over emphasised. The national nutrition strategy for Zimbabwe recommends an intake of 5 fruit and vegetable servings per day. The diversity of vegetables that are being consumed is very low. Most common ones are Covo, rape, and cabbage.

Indigenous vegetables, such as bonongwe, nyeve, manyanya and, mutangyetyange, and rapoko, which belong to the vegetables (Green leafy vegetables) food group, are highly suited to fill the nutrition security and nutrient diversity gap, and another example of promoting indigenous foods. Available data on the more commonly consumed varieties point out that indigenous vegetables contain antioxidants that can also provide significant amounts of beta carotene, iron, calcium and zinc to daily diets ${ }^{87}$. However, some of these species still battle with a stigma of 'food for the poor', or 'food for chronically ill', but despite that, interest in indigenous vegetables has risen considerably over the past years. Several programmes have been implemented, with some still being implemented, with the aim of promoting household nutrition security through production/cultivation of diversified nutrition-dense crops. Promotion of indigenous vegetables value chains, which are low input and to some extent drought-tolerant crops, can complement the nutrition-sensitive agricultural programmes such as the Livelihoods and Food Security Programme being coordinated by FAO.

Besides enhancing household nutrition and livelihoods, indigenous vegetables can contribute to increased household income. The demand for the indigenous has increased without large investments to promote the food. High end formal supermarkets, such as Bon Marche and Food Lovers, are now selling indigenous vegetables, thus creating a market and demand for these vegetables. This in turn is

87 Maroyi, Allfred. (2011). Potential role of traditional vegetables in household food security: A case study from Zimbabwe. African Journal of Agricultural Research. 6. 5720-5728. 10.5897/AJAR11.335. 
creating opportunities for rural smallholder farmers to supply the urban market with indigenous vegetables. It was mentioned that the biggest market for indigenous vegetables is the urban market.

The vegetables are already adapted to the various parts of the country where they grow naturally and therefore are climate-resilient. Most of the vegetables grow to maturity/harvesting within a short time (ca. 4 weeks) enabling farmers to be food secure even if mid-season droughts which affect conventional crops occur.

Investing in this specific value should focus on, but not be limited to:

- Carrying out an inventory of locally available food species (wild and cultivated) for the selection of specific crops to fill nutrient gaps existing in the target areas (sector?).

- Addressing the propagation issues for seeds of indigenous vegetables to ensure all-year availability.

- Knowledge-gap filling to improve cultivation practices for indigenous vegetables, aiming at elimination of drudgery in the field and introduction of innovative cultivation approaches based on the blending of traditional knowledge and scientific findings.

- Encouraging use of nutrition information, as well as any other information on useful traits present in indigenous vegetables for promoting their greater adoption by value chain actors.

- Including indigenous vegetables in home gardens and projects' business plans developed at the national level to strengthen home consumption and marketing of these nutritious species.

- Training in value addition, various cooking methods to make vegetables tastier.

- Supporting research on the geographical distribution of the various species of indigenous vegetables in Zimbabwe and researching the bioavailability of the nutrients, which has been reported in some scientific studies to be higher than that of exotic vegetables. For example, a comparison of group means for exotic, adapted and indigenous vegetables for carotene and vitamin $\mathrm{C}$ contents revealed greater mean values of vitamin E, folate, calcium, iron, zinc, total phenols and antioxidant activity in indigenous than in exotic vegetables ${ }^{88}$.

By investing in the value chain of these crops, the project could increase household consumption of indigenous vegetables, and contribute to increased availability of a variety of nutritious vegetables in the food environment. As mentioned earlier, the demand for these vegetables is increasing. If need be, the value chain promotion could include an intervention to further promote these foods (e.g. through food fairs), especially for the rural population, to enhance diet quality.

Suggested partners: The Marondera University of Agricultural Sciences \& Technology (MUAST) is working with a ZWL $\$ 3,954,600$ grant from the Ministry of Higher and Tertiary Education, Innovation, Science and Technology Development (03. 2020-03. 2023) on a research project titled: Sustainable Production and Commercialization of African Indigenous Vegetables (AIVs): A Value Chain Approach: Improving AIV Seed Systems to Creation of Healthier Diets and Sustainable Markets.

\section{Biofortified crops}

To combat micronutrient deficiencies (as described in the nutrition situation analysis), the Government of Zimbabwe launched the Zimbabwe National Food Fortification Strategy 2014-2018 to address the micronutrient deficiency burden revealed in the country. In June 2017, the Government of Zimbabwe made it mandatory to fortify processed foods with micronutrients, such as Vitamin A. The food vehicles targeted for fortification included sugar, cooking oil, maize meal, and wheat flour (ZimVAC, 2018). However, due to the inflationary environment and high poverty in rural areas, the cost of fortified foods is beyond the reach of the targeted populations.

88 Yang, Ray-Yu \& Wu, Wan-Jan \& Oluoch, M.O. (2009). Are African indigenous vegetables nutritious? Evaluation and comparison of nutritional values among indigenous, adapted, and exotic vegetables in tropical Africa. Annals of Nutrition and Metabolism. 55. 170-171. 
The diets of the poor are often monotonous and consist mostly of maize and (a limited variety of) vegetables. While it is important to continue efforts to increase dietary diversity and quality as a longterm solution to all forms of malnutrition, consumption of biofortified crops allows many people to increase dietary micronutrient adequacy simply by substituting a micronutrient-poor staple with its micronutrient-rich counterpart. A growing body of evidence demonstrates the efficacy and costeffectiveness of this strategy ${ }^{89}$.

The advantage is, that other development partners have already invested in resource-intensive steps of biofortification programmes in Zimbabwe; breeding of locally adapted varieties that have higher amounts of bioavailable micronutrients, registration and release of different varieties and, as well as demand creation beyond farm gate activities. As a result, the following varieties have been released in Zimbabwe and are promoted by the Government of Zimbabwe in partnership with FAO and HarvestPlus;

- Vitamin A fortified orange maize (high-yielding, disease and virus-resistant, drought-tolerant, sweeter taste, high in carotenoids) and protein maize. Varieties: ZS242, ZS244, ZS246, ZS248.

- High iron beans (High-yielding, virus-resistant, heat and drought-tolerant). Varieties: NUA45 and Jasmine.

More than 250,000 households (12 districts: Mutare, Makoni, Mutasa, Guruve, Mt Darwin, Bindura, Kwekwe, Shurugwi, Gokwe North, Gokwe South, Mazowe and Zvimba) have been reached with biofortified maize and bean seeds both directly and through market-led interventions.

The varieties have been licensed to private seed companies to produce seed for sale to farmers. The commercial seed has been distributed through agrodealers, government agricultural input support schemes and non-governmental organisations. There are good examples of connection established between processors and farmers; a successful example is Skybrands, an orange maize processing company started by youth. Awareness has been raised on vitamin A maize and iron beans through consumer education, advertising, recipe demonstration and media outreach ${ }^{90}$. Key informants report that fortified crops are sold at a higher price, and farmers who have been sensitised to their benefits for household nutrition and health, keep produce for own consumption.

A recent study by FAO Zimbabwe (LFSP - Nutrition and Biofortification Rapid Nutrition Study, February 2020 - report yet to be published ${ }^{91}$ ) revealed that $89.7 \%$ of the 477 households sampled in the 12 districts implementing the biofortification programme had good knowledge of biofortified foods, $76.8 \%$ grow biofortified crops, one in every 3 households indicated that they consume vitamin $\mathrm{A}$ biofortified orange maize and one in every 3 households also indicated that they consume iron biofortified beans (NUA45).

The objective of selecting value chains of biofortified crops is not to promote increased consumption of staples but rather to substitute consumption of nutrient-poor varieties with nutrient-rich ones. This pathway should therefore always the complemented with strategies to diversify food production and consumption ${ }^{92}$. The pathway to increased consumption is through increased availability and accessibility of foods with high nutritional quality on the market and through own consumption of smallholder farmers producing biofortified crops.

Based on the literature and interviews of key stakeholders of biofortification in Zimbabwe, the following actions are recommended when selecting the value chain of biofortified crops:

- For youth, focus on crops that have short growing times (e.g. 3 months) and have higher returns (dollar invested vs dollar return). For example, The HarvestPlus iron bean value chain was a success as many youths were interested in participating in the value chain.

89 Hotz C, Loechl C, de Brauw A et al. (2012a) A large-scale intervention to introduce orange sweet potato in rural Mozambique increases vitamin A intakes among children and women. Br J Nutr 108(1):163-176. https://doi.org/10.1017/S0007114511005174.

90 https://www.harvestplus.org/where-we-work/zimbabwe-0.

91 https://twitter.com/LFSPZim/status/1269959893357903872.

92 FAO 2017 Nutrition sensitive agriculture and food systems in practice. Options for interventions. 
- For an easier start, focus on value chains other than maize, as the maize value chain is a highly controlled value chain in Zimbabwe, offering more challenges in promoting this value chain as compared to other commodities.

- Consider tapping into government programmes, and possibly home grown school meal programmes, to ensure markets for the new crops. Seed companies are hesitant to invest in new crops, for which the market is uncertain.

- Pay special attention is to breaking the mistrust that the private sector has concerning smallholder farmers, e.g. the perception that smallholder farmers, when contracted, will market the product on the side when they become aware of its additional value.

- Start with small processing companies. Regular processing companies require higher volumes to be cost effective, if the Agriculture Production Groups cannot meet these volumes it might be better to start with small companies.

- Increased demand can be boosted by developing healthy processed products, such as healthy snacks and complementary foods, and other products made from biofortified crops. E.g. orange maize can be processed into maize meal, samp, fermented drink, and there is definitely a market for these products.

- Invest in raising awareness of the benefits of the production and consumption of biofortified crops. During the National Nutrition Survey (2018), $6 \%$ of the households were aware of biofortified crops and, of these, 33\% had grown or purchased biofortified crops in the last 6 months. Utilisation of biofortified crops was highest in Shamva, Bulilima, Harare, Chipinge and Chimanimani.

- Also, for this value chain, it is important that smallholder farmers engage in the interventions keeping produce for own consumption.

Suggested partners for collaboration: HarvestPlus in Zimbabwe is a strategic technical partner to the Under the Livelihoods and Food Security Programme (managed by FAO) on biofortification. It is recommended to build on their value chain approach and related lessons and experiences.

\subsection{Strengthening value chain linkages}

An underlying issue in failing food systems is the poor value chain linkages. This was also a recurrent issue addressed in the interviews: the need to improve linkages within agricultural value chains - from farmers to processors, to agribusinesses, to consumers, etc. Strengthening these linkages helps bring the SHF and other VC actors closer together and increases their access to resources, knowledge and skills. Together, this can result in more income or a steadier income, thereby influencing food and non-food expenditure of rural households (see also pathway 1 ). This again can indirectly lead to nutrition and reduced climate vulnerability outcomes. Investing in making these linkages stronger and more efficient can therefore achieve multiple benefits for the entire food system by booking economic, climate and nutrition gains. In addition, for any future VC innovations to take place (in relation to climate resilience, inclusivity, etc.), effective linkages are also crucial.

Based on the interviews and a GIZ guide on Growing Business with Smallholders - A Guide to Inclusive Agribusiness (2014), the following entry points have been identified. This guide describes how it can contribute to food system outcomes.

- Managing risks for smallholders: bad weather, pests and disease, sickness within households, etc. SHF usually lack access to effective risk sharing mechanisms such as insurance, livelihood diversification and resilient seeds and crops. SHF thus would need support in improving their production factors: seed, feed, fertilisers, crop protection and financial support. These resources, knowledge and skills will also increase the adaptive capacity of SHFs to adapt or even cope with climate-related hazards, thereby reducing their overall vulnerability to climate change.

- Invest in relationship building: Trust and access to finance are basic requirements for success in value chain development. When lacking, it erects barriers between companies and smallholder farmers (see Figure 23).

- Providing market information: Smallholders also face difficulties accessing up-to-date information on issues such as market prices for their products, weather forecasts, potential business partners beyond the local level, available inputs, modern production and marketing technologies and 
agricultural practices. Having access to this kind of information will increase the economic and climate resilience of SHFs.

- Investing in infrastructure: poor roads, unreliable transportation, long transport times, lack of electricity all contribute to products not reaching potential markets. Moreover, upgrading could involve upgrading local shops, constructing new collection points or implementing self-run logistics and distribution systems.

- Promote collaboration: this can be done by organising SHF into groups: agricultural clusters, women's groups, youth groups, etc. Or by developing multi-stakeholder partnerships along certain value chains (see 7.2 Implementation Arrangement). ICRISAT for example has been working with successful innovation platforms where different chain actors themselves collectively identify the challenges and came up with solutions. This could be around various issues related to climate resilience, food \& nutrition security and inclusion. By exchanging information, resources and tips, the adaptive capacity of SHF could for example increase.

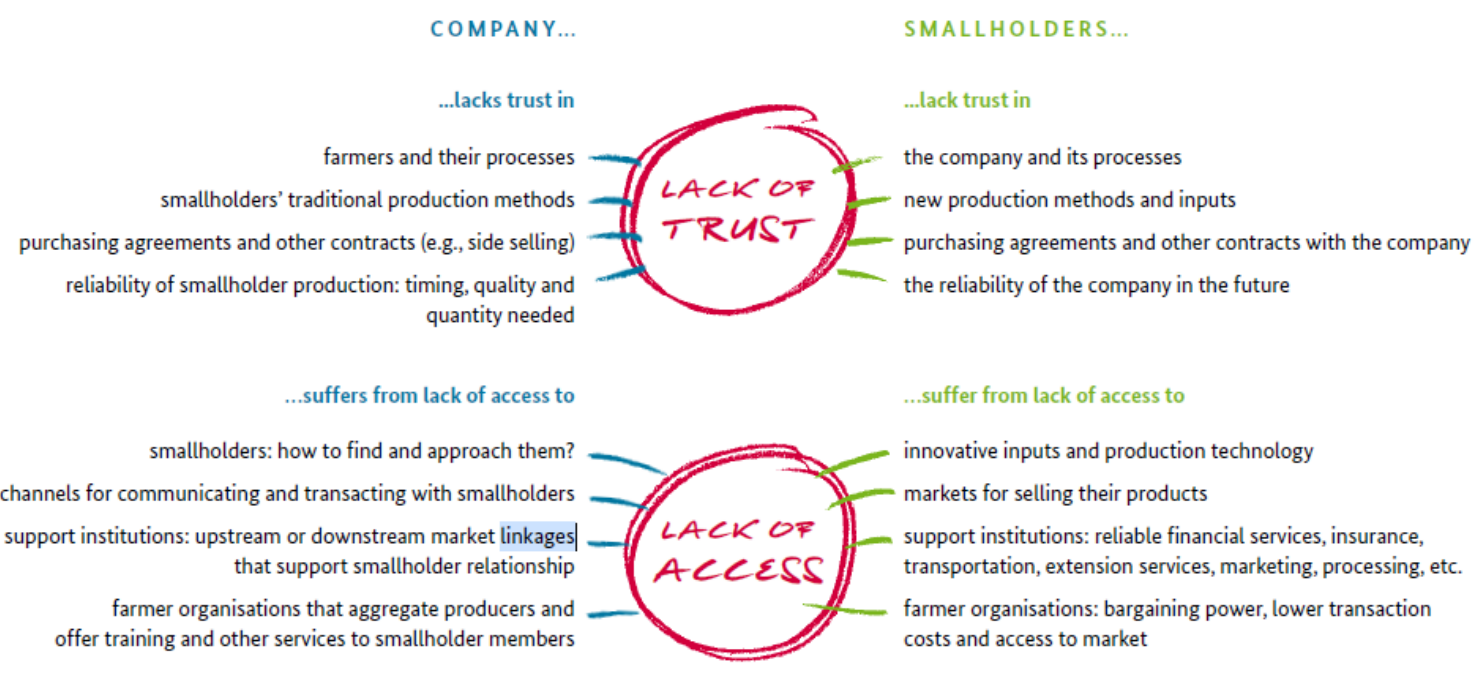

Figure 23 The mirror of relationship challenges between agribusiness and SHF 93 .

93 GIZ. 2014. Growing Business with Smallholders. A Guide to Inclusive Agribusiness. 


\subsection{Women's empowerment}

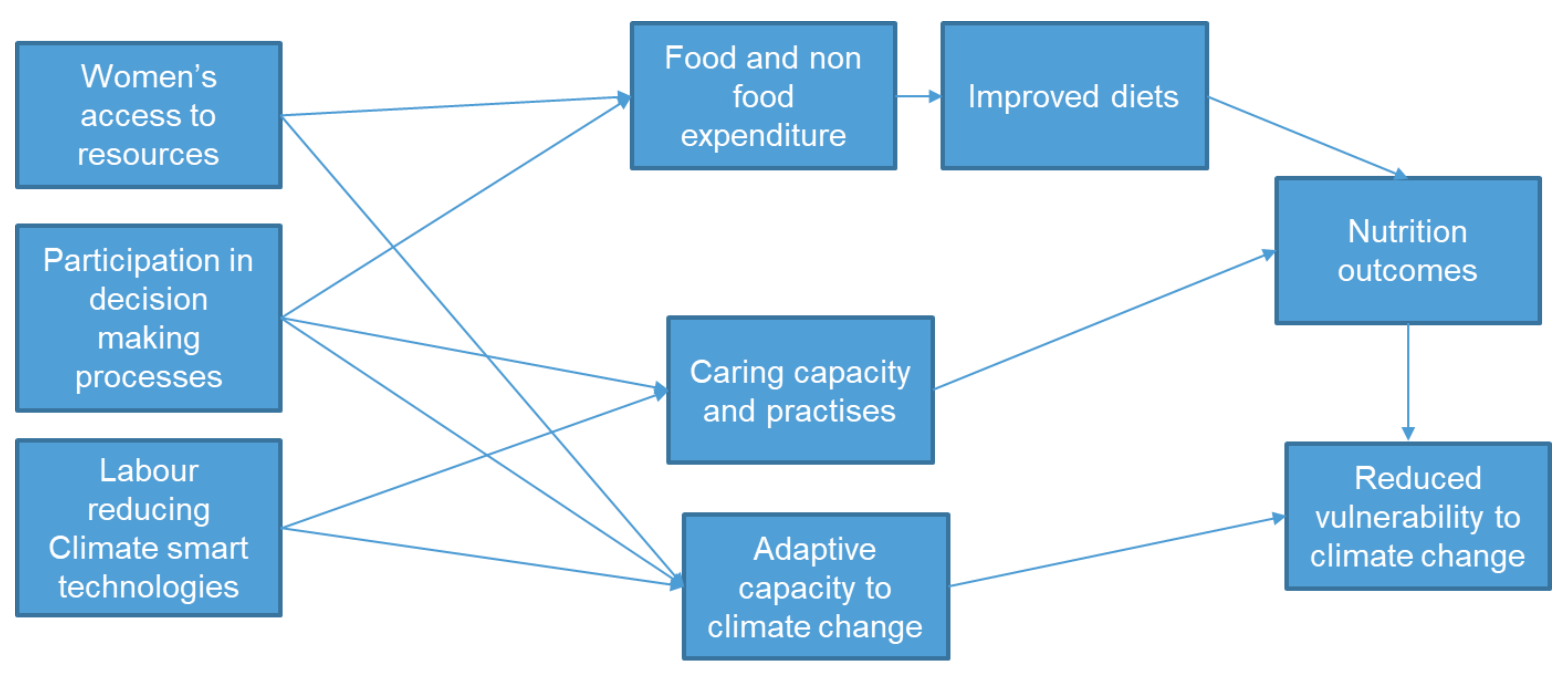

Approximately $80 \%$ of women in Zimbabwe live in communal areas where they constitute $61 \%$ of the subsistence farmers and provide $70 \%$ of the labour. Female-headed households are mostly categorised as poor and consist of $35 \%$ of households ${ }^{94}$. Some of the main identified gender constraints in the agricultural value chain are ${ }^{95}$ :

- Production: lack of land ownership, land grabbing by male relatives, low paid employment, limited assets, lack of livestock ownership, large share of agricultural labour.

- Markets: lack of facilities, safety issues and unfair prices.

- Transportation: unsafe transportation, travelling at night.

- Limited participation in decision-making processes: at $\mathrm{HH}$ and community. Decisions around farm management, investments, community development.

- Other: limited access to (climate) finance, limited participation in capacity building activities.

These issues increase gender inequality and make women in Zimbabwe more vulnerable to malnutrition, more financially insecure and more vulnerable to climate-related impacts. As mentioned earlier, women are also perceived as one of the most vulnerable groups in terms of nutrition and climate change impacts. By empowering women, interventions can support men and women to benefit equally from food systems outcomes. The flowchart above illustrates this by using an inclusive and resilient food systems perspective: investing in female empowerment through 1) access to resources, 2) participatory in decision-making processes and 3) labour reducing climate-resilient technologies can eventually result in nutrition outcomes and reduced climate vulnerability outcomes for women and men.

\section{Entry points for women's empowerment}

- Selection of value chain and crops: For the selection of value chains, IFAD has indicated to not only look for low hanging fruits in terms of commercialisation considerations. They also want to take nutrition, climate, youth and gender considerations into account. Elaborate gender considerations per food group have therefore been listed in the value chain overview for the Zimbabwean context in Appendix 3 - section 8.3.

- Gender Action Learning System (GALS) to promote gender transformation. IFAD mentions in the SACP concept note that the project intends to qualify as 'gender transformation' in line with the IFAD11 mainstreaming commitments. In addition, SACP wants to incorporate appropriate and context-specific set of activities to ensure gender transformation and improved nutrition are achieved (SACP concept note). This will require a critical examination and strategy to address underlying norms and dynamics contributing to gender inequality. According to gender researcher Sandra Bhatasara, for rural women in Zimbabwe, this means focusing on institutional changes around access to justice. Many women make use of traditional courts and are unaware of their rights

\footnotetext{
94 SACP concept note.

95 Interview with Dr. Sandra Bhatasara - University of Zimbabwe.
} 
and how to seek justice. Also the other way around, the Land commission might not be fully aware of the local reality around gender inequality related to land conflicts and boundary disputes ${ }^{96}$. The use of Gender Action Learning System (GALS) is a methodology that is useful for achieving gender transformation. It is a community-led empowerment methodology that can be complementary to a food system or a value chain development approach. Poor women and men are put in the centre of GALS and are perceived as drivers and shapers of their own development rather than victims. Through participatory processes and simple mapping and diagram tools, men and women jointly identify and address obstacles in their environment. This forces them to take more control over their personal, household, community and organisational development to improve income, food and nutrition security in a gender-equitable way. Ultimately, GALS can promote collaboration between vulnerable and powerful value chain actors ${ }^{97}$.

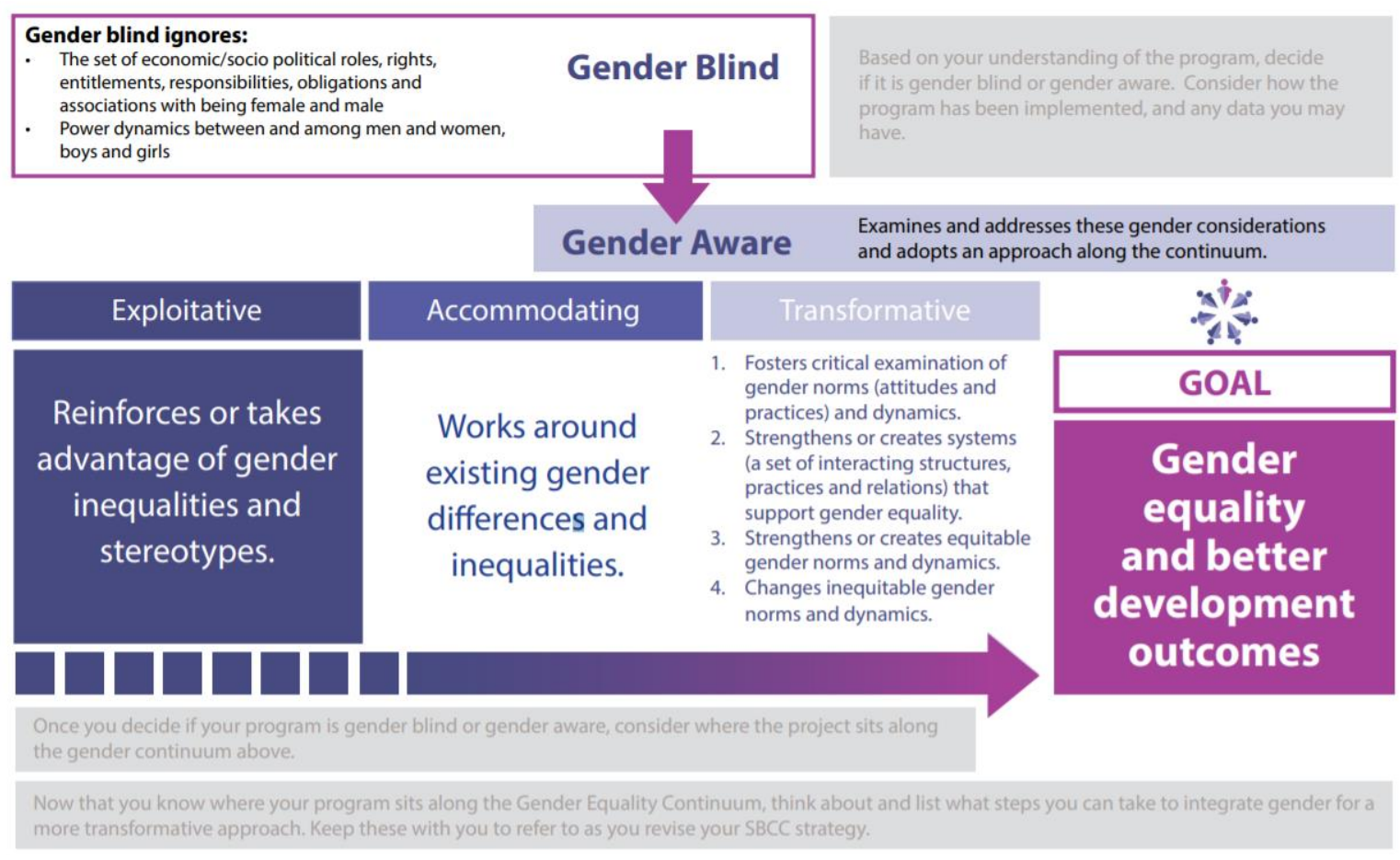

Figure 24 Gender Equality Continuum ${ }^{98}$.

- Invest in a thorough baseline around households based gender analysis. According to gender researcher Sandra Bhatasara, such a baseline which also covers gender politics and intersectionality analysis is lacking. Such understanding is necessary when transforming gender relations and social inequalities.

- Gender targeting: currently many value chain or rural development interventions target the head of the households, which implies that women are automatically out.

- Ensure community-wide gender sensitisation: encouraging active participation and targeting women in rural communities might be sensitive. A way to overcome this is to clearly communicate the expected benefits for the broader community and its local economic development.

- Work with groups versus individuals: experiences from other projects recommend collaboration with formal or informal women's groups rather than on an individual basis. Strengthening capacities of organised female groups have proven to be less sensitive.

- Promote women leadership across value chain activities: identify successful women within different parts of the value chain and bring them together in a leadership platform for instance. They can become a source of inspiration for other women and can foster collaboration among value chain

96 Idem.

97 Oxfam \& GIZ. 2014. Gender Action Learning System. Practical guide for transforming gender and unequal power relations in value chains.

98 Adapted from Interagency Gender Working Group (IGWG) 2017. https://www.igwg.org/wpcontent/uploads/2017/05/FG_GendrIntegrContinuum.pdf. 
actors. A recurrent issue raised in the interviews was the need to improve linkages within value chains: farmers to processors, to retailers, to consumers, etc.

- Invest in value addition for women: there are untapped opportunities in capacity building in value addition. For example, currently during the Covid-19 lockdown, many communities grow perishable products such as tomatoes which are thrown away. If they would have had training in processing, they would have been able to still earn money from these crops.

- Climate-resilient technologies that reduce labour burdens: in order to engage women and get them interested in training and adoption of climate-resilient technologies, it is recommended to select those technology that reduces time and labour burdens on women.

- Promote safe working environments: Rural women are often involved in production as some other activities along the value chain might not be safe. Safety issues are related to female unfriendly facilities, harassment on markets, unfair prices, unsafe transportation, travelling by night. If women are to be encouraged to work along the entire value chain, these issues need to be prioritised.

- Include men in women's empowerment activities: a common phrase is that we need both women and men to address gender inequality. Therefore an overall recommendation would be to critically analyse for what activities is it effective (or necessary) to invite and include both men and women.

\subsection{Youth inclusion in agricultural value chain development}

Empowering and engaging rural youth in the selected value chains is one of the activities mentioned in the COSOP and the SACP concept note. The primary target group will comprise at least $30 \%$ youth. Despite youth not being considered the most vulnerable to malnutrition nor climate change, they are seen as an enormous labour potential for agricultural development. Moreover, they can support more vulnerable groups by being part of rural households and communities. Therefore, by actively engaging youth and promoting youth-sensitive agriculture it can create rural employment, reducing ruralurban migration and make food systems more inclusive and innovative.

However, the following youth constraints in agricultural value chains currently exist. These have been identified through literature reviews and interviewing key informants:

- High unemployment rate of youth: one of the main drivers impacting Zimbabwean food systems is this high unemployment rate of youth which is estimated to be at least $84 \%$ of the unemployed (COSOP) contributing to rural-urban migration to look for employment opportunities (brain drain).

- Negative attitude towards agricultural production: Affluent youth with higher levels of education tend to have a more negative attitude towards agricultural production because of a lack of quick return and the perception of a 'dirty job'. Poor and rural youth tend to have a more positive attitude towards agriculture.

- Financial exclusion: due to a lack of formal jobs, collateral and land they often face difficulties accessing finance and loans. Need some starting capital.

- Low decision-making power: Youth currently do not actively participate in community decisionmaking processes as far as development is concerned. They are excluded from gatherings and are therefore not represented in rural governance.

- Climate change \& rural-urban migration: Climate change has severe impacts on agriculture and intensifies rural poverty and food insecurity. Combined with the high level of youth mobility, this drives young people away from rural areas to urban areas or neighbouring countries to improve their way of life.

Considerations and opportunities for youth inclusion

- Disaggregate youth populations: from the start of the project, be aware of the diversity among youth populations (gender, rural/urban, level of education part of value chain/crop preference) and target value chain analysis accordingly. The project should not design one standardised approach, but tailored approaches to sub-populations of youth.

- Participatory capacity needs assessment: Make an inventory of their existing capacities, their preferences and their capacity gaps. Youth mainly prefer to make quick returns and work in specific parts of the value chain such as marketing and processing over production, but might depend on 
sub-populations. Due to high unemployment rates, youth are now forced to engage in traditional agriculture, which might not be their preference. Carry out such an assessment in a participatory way, so that youth are engaged and motivated early on in the planning stage of the project which has also been mentioned as an mitigation measure in the COSOP.

- Selection of value chain and crops: For the selection of value chains, IFAD has indicated its intention to not only look for low hanging fruits in terms of commercialisation considerations. They also want to take youth considerations into account. Therefore, youth considerations per food group have been identified and listed in the value chain overview for the Zimbabwean context in Appendix 3 section 8.3.

- Engage youth in value chain selection: Effective youth programming is linked for a great deal to the selection of value chains; aligned to their interests and capacities. A recommendation would be to actively include youth and women (possibly through existing structures/clusters) in value chain selection. USAID has identified and tests selection criteria effective in working with at-risk youth. These include ${ }^{99}$ :

- Attainable capital and skill requirements. Youth are less likely to have the assets, experience or skills of adult populations. Therefore, value chains that require high capital investments or skill levels may not be appropriate.

- Quick monetary impact. At-risk youth often need to see a fast return on their activities to remain engaged, in light of their financial obligations.

- Matched to youth interests. Being sensitive to youth priorities is important, as youth are often unwilling to engage in sectors that they do not consider to offer adequate long-term prospects.

- Appropriate vis-a-vis family obligations and peer perceptions. Youth are often particularly sensitive to the expectations and opinions of those they are close to, which can influence their selection of which value chains to engage in and in what capacity.

- Acceptable for personal safety and health. At-risk youth tend to have the weakest ability to advocate for themselves, and thus may need to accept work in very unsafe conditions and be assigned particularly risky tasks.

- Innovative forms of knowledge exchange and capacity building: Youth are known for their open attitude and quick adoption of innovation and new practices. This is essential when tackling climate change for example, which requires adapting and updating old practices. Youth can therefore act as a bridge between traditional farming techniques and new climate-resilient technologies, helping to shift food systems towards becoming more inclusive and resilient. Hence, this outlook can be built upon with training on developing business plans, rural entrepreneurship development, agroprocessing, climate data, climate-resilient technologies and through youth exchange groups.

- Collaborate with traditional leaders: a lesson learned from the FAO Green Jobs for Youths Project is the development of community implementation committees which consist of traditional community leaders who interact and mentor rural youth. These are developed early on in the project and support the project by selecting motivated youth for value chain development. At the same time the engagement of these leaders strengthens the ownership and buy in of traditionally powerful actors. By acknowledging the youth, they become more visible and could ultimately strengthen their decision-making power.

- High level of mobility: Young men and women are very mobile as they migrate for job opportunities or marriage. This offers challenges as well as opportunities. Key informants mentioned the difficulty of building capacities, relationships and setting up structures for collaboration. On the other hand, this mobility could also be used as youth might be more flexible. The FAO-and-DFID-supported Zimbabwe Livelihoods Food Security Programme (LFSP 2013-2021) has demonstrated that technologies promoting moveable business are more lucrative for the youth. Hence, the IFADs idea to promote mobile processing units and marketing services for women and youth (COSOP).

Click here to see a FAO compilation of youth initiatives in agriculture to address the impacts of climate change.

99 USAID - Market Links. 2020. 4.2.2. Key Constraints and Promising Strategies in Applying the Value Chain Approach with Youth: https://www.marketlinks.org/good-practice-center/value-chain-wiki/key-constraints-and-promising-strategiesapplying-value-ch. 


\subsection{Capacity on nutrition and climate of agricultural extension workers}

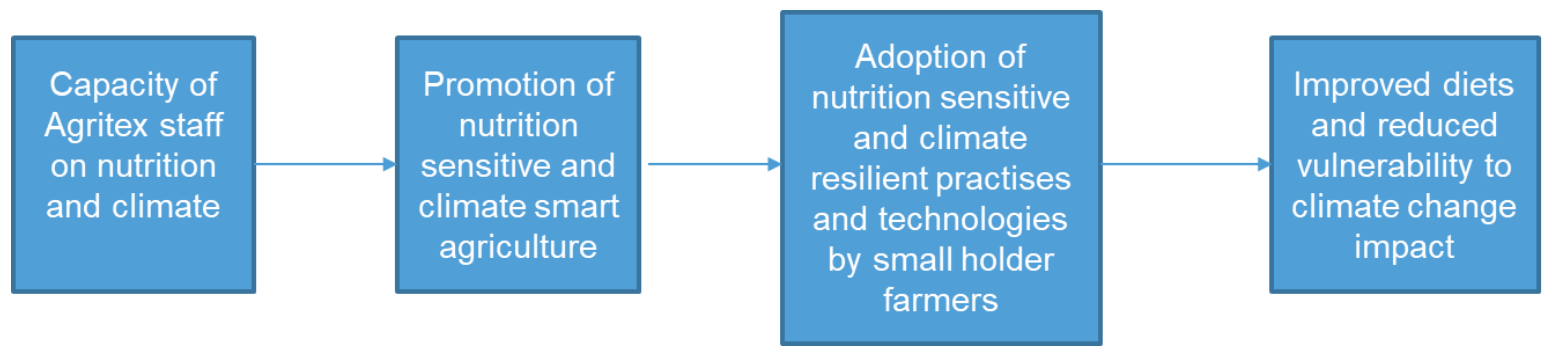

Agricultural extension is invaluable in teaching farmers how to improve their productivity by among other roles translating new knowledge into new farming innovations. The unfolding impacts of climate change, and the need to improve household nutrition, makes it more critical for extension officers to be continually trained in climate-smart and nutrition-sensitive value chains to benefit farmers. To achieve this extension, officers must have access to the knowledge and equipment (e.g. transport, ICT gadgets) to allow them to efficiently reach out to farmers.

The interviews with key stakeholders confirmed the important role that extension services play for the adoption of climate-smart and nutrition-sensitive agricultural practices. 'In Zimbabwe, Agritex is the link between farmers and input and output markets. Agritex is crucial in facilitating and getting access to the farmers by both public and private players in various value chains'. Exchanging knowledge and innovations with smallholder farmers (and building on their own solutions) is an essential driver of the food system transitions into resilient production systems and improved diets.

Having said that, the enhancement of nutrition within the extension structure of government is lacking according to the informants. Agricultural Extension officers are well versed with defining nutrition requirements of crops and livestock, but they lack the human nutrition element. There is a need to inculcate human nutrition knowledge in agriculture extension services, including behaviour related to WASH. When it comes to climate, the Agritex staff requires training as technologies are changing, especially with climate-smart technologies. In an interview, the Director of AGRITEX indicated that currently the technical pool of expertise is there within the department but what is needed is continual capacitation since technologies are changing every day, especially in the face of climate change. However there is some brain drain among agricultural extension workers, so the project should come up with measures to retain staff.

According to the director of Agritex, extension workers do promote nutrition-sensitive agriculture (nutrition gardens, production of indigenous chicken, fisheries) but it takes time for the farmers to implement it. For climate change adaptation, extension workers are promoting diversification of crops and specific drought-tolerant crops.

Regarding climate information, the government acknowledges the importance of strengthening capacity in weather, climate research and modelling in their national Climate Policy (2016):

- 1.5. Provide relevant training on weather and climate research and modelling to practitioners working with communities.

- 2.6. Capacitate the Department of Climate Change Management to be a climate change information hub and clearinghouse to generate, coordinate, collect, collate, store, retrieve and disseminate reliable, high quality and up-to-date data and information, and develop guidelines and tools for the use of climate data in development decisions.

- 2.8. Set up climate information hubs in every province to collect primary information, and act as dissemination points for refined climate knowledge.

The extension officers also know about the importance of climate information, but the flow of information systems has not been robust enough to gather this information on a regular basis in the past decades to the extent that extension officers do not care whether the information is there or not. 
In investing and building upon agricultural extension, we recommend the project focus on:

- Critically reviewing current training and communication pathways for climate information flows and knowledge dissemination.

- Invest in people-centred early warning systems (see also 5.5.) ${ }^{100}$ :

- Efficient EWS requires strengthening of local capacity of communities. For example, the development of local management plans involving local authorities and leaders.

- Promote and invest in local community means of communication to disseminate early warning information. Successful examples of local communication can be found in Mola communal lands where it has been used to report incidences of crop raiding by wildlife. The location of a communication station has proven to be key as they can result in early dissemination of warning information.

- Development and facilitation of disaster education programmes within local communities. The Civil Protection already started with this, but a concrete suggestion is to come up with a standard training manual for disasters such as floods.

- Training frontline extension officers/workers on climate-smart and nutrition-sensitive value chains, facilitation and training skills and group dynamics. The specific climate-nutrition interventions proposed by extension officers can also be assessed for effectiveness. A study is currently being carried out on 'The impact of adopted climate change adaptation strategies on nutrition outcomes'. This assessment can give policy makers, extension officers and farmers the evidence on how specific mitigation and adaption measures can impact nutrition. This study will soon be published and Lesley Macheka can be contacted for the outcomes of this publication.

- Training farmers (M/F) in concrete CSA techniques and nutrition-sensitive value chains and farming as a business (markets, supply chain logistics, access to loans etc) importance of household nutrition.

- Capacitating frontline extension workers with transport, ICT gadgets to enable them to communicate with farmers, and input and output markets.

- Facilitate extension officers/workers to mount demonstrations of new technologies on farmers' fields.

- Farmer exchange visits to successful value chains that have been implemented by other smallholder farmers as a way of boosting their confidence.

- Strengthening collaboration with other ministries/departments that have got a stake in farming, e.g., Ministry of Women Affairs, Community, Small and Medium Enterprises Development, Ministry of Youth, Sports, Arts and Recreation, and Food and Nutrition Committees.

- Training in non-agricultural food value chains that are climate-smart and nutrition-sensitive such as edible insects, indigenous vegetables and beekeeping.

- Explore the integration of indigenous knowledge systems (IKS) into climate information services. The IPCC notes that indigenous forms of knowledge are becoming increasingly relevant for climate services. This observation is also true in Zimbabwe where some locals continue to rely on indigenous knowledge systems (IKS) in climate-related decisions. National Climate Change Response Strategy aims to 'Develop frameworks for integration of indigenous knowledge into science-based early warning systems to enhance decision-making on agricultural management and disaster risk management ${ }^{101}$.

100 Gwimbi, P. 2007 the effectiveness of early warning systems for the reduction of flood disasters: some experiences from cyclone induced floods in Zimbabwe. Journal of Sustainable Development in Africa (Volume 9, No.4, 2007).

101 Zimbabwe's National Climate Change Response Strategy. 2012. 


\subsection{Reduce post-harvest losses}

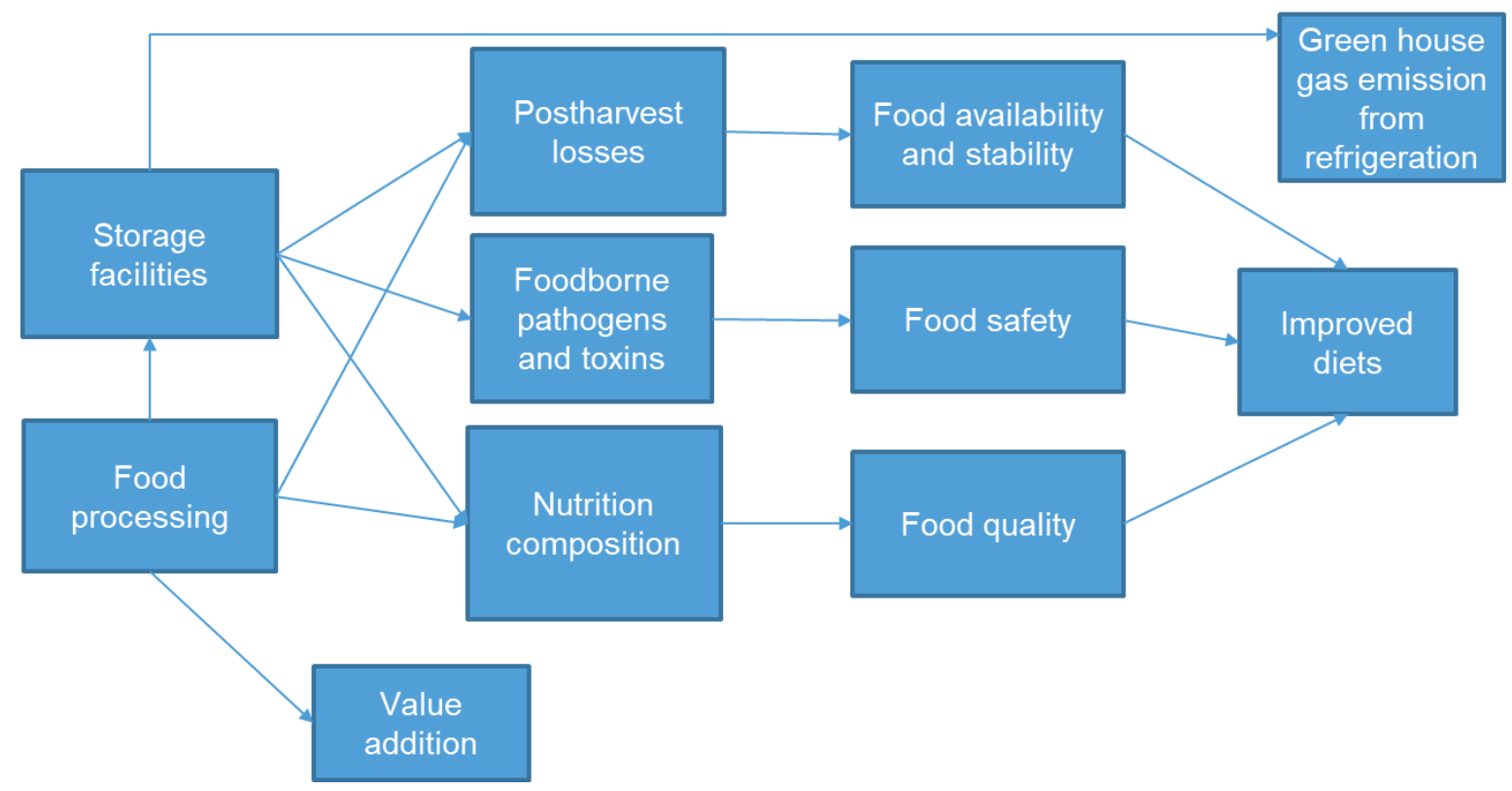

Through investing in storage facilities, training and technology for food processing, the project can help reduce harvest losses, which will increase the year-round availability of food. Improved storage and processing will reduce the food-borne pathogens and toxins in the food and enhance its safety. Nutrients can be lost if food is not properly processed or stored, hence investing in that will also improve food quality. Addressing availability, stability, safety and quality of food will contribute to improved diets. Processing techniques that make cold storage unnecessary, such as drying, can be increased, which will help to reduce GHG emissions from refrigeration.

In order to reduce food loss and waste, the team recommends the following:

- Make value chains less labour-intensive and more profitable by providing appropriate and efficient harvesting and post-harvesting machinery for the selected value chains. Machinery used in large scale farms may not be appropriate for small land holdings in smallholder farms. The machinery should also be user-friendly to women (see also the recommendations under pathway 6.4 Women's empowerment).

- Invest in bird-scaring technologies to reduce losses for crops vulnerable to bird damage. For small grains, bird scaring is labour demanding and a barrier to many farmers interested in growing them.

- Invest in market development/linkages to enable farmers to sell produce at competitive prices. This will include organising farmers into groups so they can accept more lucrative markets which require certain threshold volumes (see also the recommendations under pathway 6.3 linkages).

- Invest in storage technologies that reduce losses during storage caused by storage pests and diseases.

Reducing post-harvest Food Loss and Waste can be considered one of the essential developments for improving food security and reducing Greenhouse Gas Emissions. SHF and other VC actors can play a crucial role in reducing these losses. 


\section{$7 \quad$ Further recommendations \& considerations}

\subsection{Selection of intervention areas}

The SACP concept notes mentions that the project will be implemented along three of the five national agriculture corridors (see list below). Along these corridors, a total of 20 smallholder production clusters will be identified and selected as the SACP implementation sites. These clusters are expected to be located within about 15 districts, in 3-4 provinces.

1. Beitbridge - Bulawayo - Masvingo - Victoria Falls;

2. Plumtree - Harare - Mutare;

3. Beitbridge - Harare - Chirundu;

4. Beitbridge - Harare - Nyamapanda; and

5. Plumtree - Masvingo - Chipinge - Chimanimani - Mutare - Nyanga.

The criteria for cluster identification include:

- Proximity to the agricultural corridor;

- Demonstrated market potential for smallholder produce aggregation;

- Realistic potential for lead enterprise engagement; and

- Agro-ecological conditions suitable for systematic adoption of CSA technologies.

This section outlines additional climate, nutrition and inclusivity considerations that could be taken into account for the selection of provinces/corridors.

Climate Change considerations:

In terms of climate change vulnerability, there are two ways of categorising areas:

1. Low rainfall areas: In case the project wants to simply target the poorest SHF facing food insecurity, then the low rainfall areas should be prioritised. Previous conclusions in this report stated that both provinces Matabeleland North and Matabeleland South can be considered most vulnerable to climate change both having the highest drought risk as well as the lowest levels of adaptive capacity of smallholder farmers to respond and adapt to this risk. In terms of irrigation, it would be interesting to invest in feasibility studies to quantify the water that is stored around these sand rivers in these areas. There is a suspicion that there is water which could be used for irrigated farming, but no study has yet been done ${ }^{102}$. Following this scenario, agricultural corridor 1 is most suitable.

Suitable corridor 1: This corridor covers all the three semi-arid provinces: Matebeleland north and south and Masvingo (see Figure 25).

2. High rainfall areas: In case the project wants to address the climate vulnerability of commercial value chains, then the high rainfall areas could be prioritised. The SHF in these areas currently have higher levels of adaptive capacity, however they are likely to face capacity challenges in the future due to shifting of agro-ecological zones (see suggestion regarding agro-ecological zones below). As agro-ecological zones 1 and 2 will receive less rainfall in the future, the SHF could have relatively less adaptive capacities to cope with drought compared to SHF in the low rainfall areas that have been experiencing this for decades. Therefore, it could be interesting to select a corridor in the high rainfall areas as well. Moreover, investing in irrigation in agro-ecological zones 1 and 2 becomes more viable as SHF need to pump for only a few hours and the rest is supplemented by rainfall, so you get the best out of irrigation and the crop. An idea could be to export some of this food to low rainfall areas ${ }^{103}$. Following this scenario, agricultural corridor 5 is most suitable.

Suitable corridor 5: This corridor covers high rainfall areas of Chipinge, Chimanimani and Nnyanga, all districts in Manicaland where specialised in commercial value chains horticulture

102 Interview with Mr. Conrad Zawe - Department of Irrigation.

103 Idem. 
(fruits, vegetables, flowers) and dairy is practiced (see Figure 25). This is in addition to semi-arid provinces of Matebeleland (Plum tree) and Masvingo.

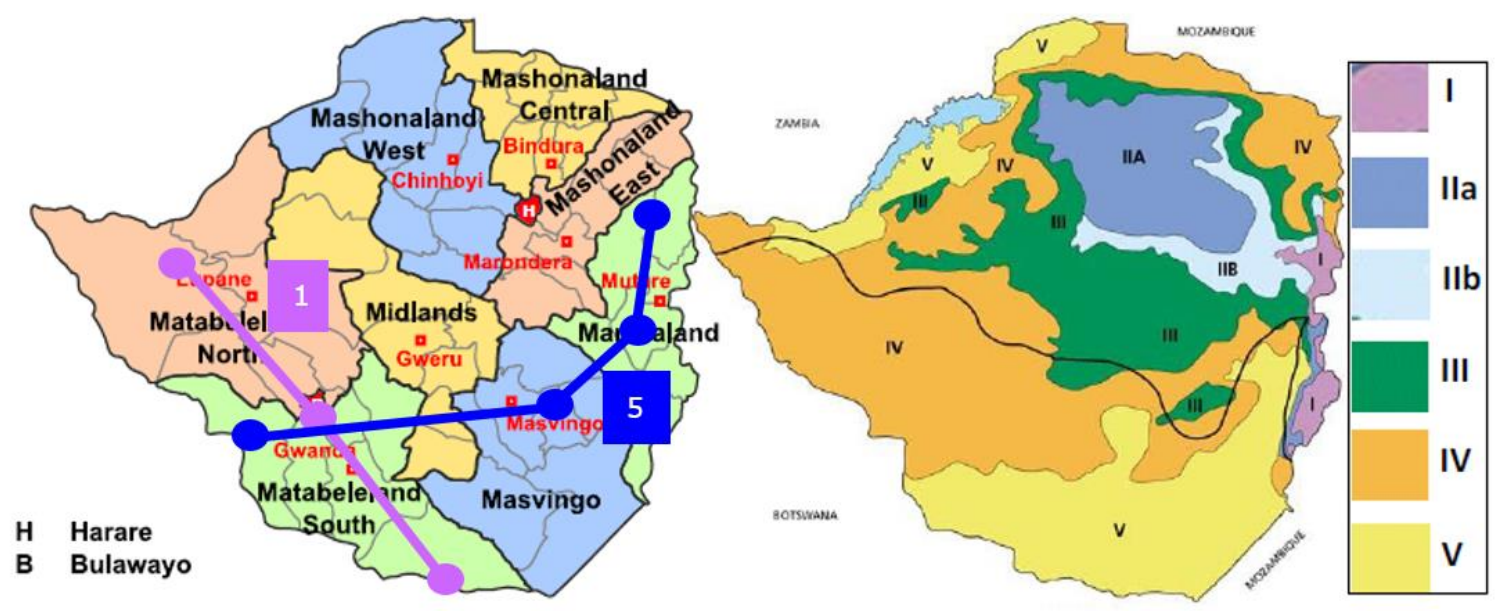

Figure 25 Map of Zimbabwe's provinces and agro-ecological regions ${ }^{104}$ Pink $=$ agricultural corridor 1 and blue = agricultural corridor 5 .

\section{Regarding the other corridors:}

- Corridor 2- Plumtree - Harare-Mutare: Besides a small part of Matebeland South, the corridor passes through a largely a high rainfall zone, i.e. NRs III, II and I.

- Corridor 3- Beitbridge-Harare-Chirundu: Besides parts of Matebeleland South and Masvingo, the corridor passes largely through relatively higher rainfall zone, i.e. NR III and II. The last part of corridor, Makuti to Chirundu is a national park for wildlife.

- Corridor 4 - Beitbridge-Harare-Nyamapanda: Same as Corridor 3, but could be a possible third choice since it covers areas active in fruit and vegetable production (from Harare to Mutoko) and semi-arid area where small grains and groundnut are popular (Mutoko to Nyamapanda).

\section{Review and update of the agro-ecological maps of Zimbabwe in line with changing climate} When we look at the agro-ecological zone map, we can see that the low rainfall areas are categorised in IV and V regions and high rainfall in I, II and III (see Figure 25) However, several key informants and the World Bank ${ }^{105}$ suggest that we have to be careful with these categorisations as these zones have shifted due to climate change, meaning that that boundaries must be reconsidered. Implications of these shifted agro-ecological zones mean different crop suitability patterns and different levels of adaptive capacity of SHF. It is therefore recommended to update these maps based on the current agro-ecological boundaries. This has also been listed as a policy priority stated in the Zimbabwe Climate policy 2016: The government will: 3.14. Periodically review and update the agro-ecological map of Zimbabwe in line with changing climate ${ }^{106}$.

\section{Nutrition considerations}

- The most food insecure regions in Zimbabwe are consistent with poverty prevalence with Matabeleland North (58 percent) and Manicaland (50\%) provinces having the highest proportion of food insecure households.

- According to the nutrition situation analysis, the provinces vulnerable to malnutrition, due to high level of food insecurity levels, and poor dietary quality and WASH practices are Matabeleland North

\footnotetext{
104 University of Cape Town. 2019. Climate Risk Assessment ZIMBABWE.

105 World Bank. 2019. Zimbabwe: Agriculture Sector Disaster Risk Assessment: http://documents.worldbank.org/curated/en/667021584421611242/pdf/Zimbabwe-Agriculture-Sector-Disaster-RiskAssessment.pdf.

106 Zimbabwe Climate Policy. 2016. P.10.
} 
and South and Mashonaland Central and South. Only Matabeleland North and South overlap with corridor 1 , recommended under climate considerations.

Gender \& Youth considerations:

- Effective gender and youth programming is linked for a great deal to the selection of value chains, rather than locations. Those value chains should be selected that are suitable for youth interests, are gender-sensitive and in line with capacities.

- Recommendation is to actively include youth and women (possibly through existing structures/clusters) in value chain analysis and selection (see also pathway 6.5 'youth inclusion').

- USAID has identified and tests selection criteria effective in working with at-risk youth include ${ }^{107}$ :

- Attainable capital and skill requirements. Youth are less likely to have the assets, experience or skills of adult populations. Therefore, value chains that require high capital investments or skill levels may not be appropriate.

- Quick monetary impact. At-risk youth often need to see a fast return on their activities to remain engaged, in light of their financial obligations.

- Matched to youth interests. Being sensitive to youth priorities is important, as youth are often unwilling to engage in sectors they do not consider offer adequate long-term prospects.

- Appropriate vis-a-vis family obligations and peer perceptions. Youth are often particularly sensitive to the expectations and opinions of those they are close to, which can influence their selection of which value chains to engage in and in what capacity.

- Acceptable for personal safety and health. At-risk youth tend to have the weakest ability to advocate for themselves, and thus may need to accept work in very unsafe conditions and be assigned particularly risky tasks.

To conclude, if the project wants to focus on the most vulnerable SHF in relation to climate (map on the left and malnutrition (map on the right), there is a clear overlap in spatial vulnerability in three provinces: Matabeleland North, Matabeleland South and Mashonaland Central.
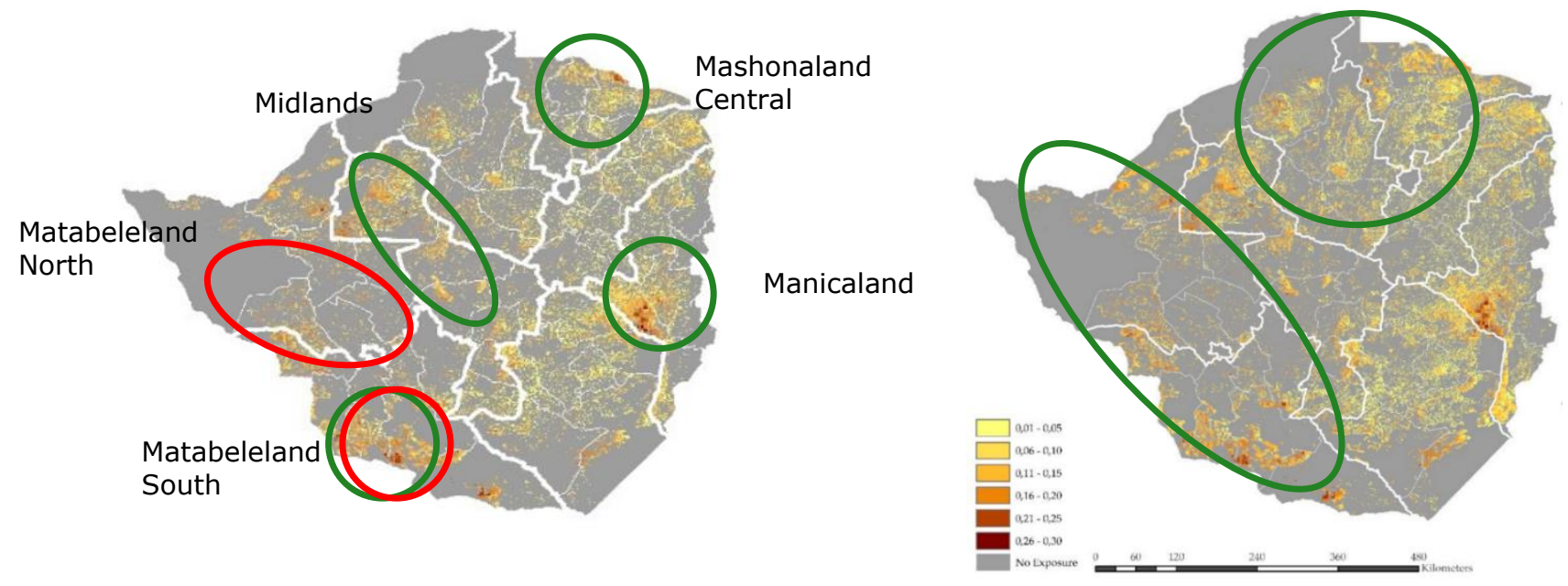

Figure 26 Left: Most vulnerable provinces according to drought risk to rain-fed agriculture (green) and adaptive capacity (red). Right: Regions vulnerable to malnutrition.

107 USAID - Market Links. 2020. 4.2.2. Key Constraints and Promising Strategies in Applying the Value Chain Approach with Youth: https://www.marketlinks.org/good-practice-center/value-chain-wiki/key-constraints-and-promising-strategiesapplying-value-ch. 


\subsection{Implementation arrangements}

\section{A. Accessing finance through the Climate Finance Facility (CFF)}

Sustainable and inclusive food systems require financial investment which are accessible for multiple value chain actors. The challenge is to find innovative architecture to use climate finance to improve and increase access to finance for smallholder farmers while also building resilience. Currently, the Zimbabwean government is pushing for the development of architecture for climate financing in order for Zimbabwean banks to become accredited by the Green Climate Fund and can start mobilising their own resources. The Infrastructure Development Bank of Zimbabwe (IDBZ) is now in the process of establishing a Climate Finance Facility (CFF) which is a ring-fenced fund ${ }^{108}$ dedicated to financing green projects in Zimbabwe. The identified priority areas are renewable energy, energy efficiency, irrigation schemes and waste management systems. The intention is to use this facility as a platform where various climate finance sources and private sector investment can finance green projects to ensure a climate-resilient economy. These funds will become accessible for both smaller institutions such as organised smallholder farmers as well as to large scale projects and initiatives ${ }^{109}$.

The World Bank published a relevant discussion paper 'Making Climate Finance Work in Agriculture'110 which contains recommendations for how climate finance can accelerate climate-smart investments in the agriculture sector. Combined with input from key informants, the team recommends the following entry points to unlock these new sources of funding:

- Create a finance-enabling environment for agriculture, this could involve better policies and regulations to mobilise and channel financial flows to farmers and to build the structures to facilitate and accelerate climate-smart inputs and other investments.

- Strengthen capacities of value chain actors on:

- (Climate) finance literacy

- How to access (climate) finance

- Developing climate business plans

- Rural entrepreneurship

- Multi-stakeholder thinking: encouraging actors to organise themselves and collaborate along the value chain

Focus on youth and gender: this will promote more accessible financing for them to access climateresilient technologies/practices and to contribute to value chain development that increase incomes for rural youth as well as their food security and nutrition.

\section{B. Working with multi-sectoral nutrition committees}

The multi-sectorial arrangements through the Food and Nutrition Committees which are found at the National, Provincial, District, and ward level are well organised to be used as channels of communications. The committees are chaired by agriculture, with the nutrition department being secretariat of the committees. As such, there is coordination, collaboration and interaction between the different departments, e.g. Agriculture, Nutrition, gender, and climate change. Such multisectorial platforms can be used in implementing the project. According to key informants, this approach will increase the likelihood that the Ministry of Agriculture will implement activities on time as it will have to report to other sectors. In implementing the project, Agriculture can be the focal point as it chairs the Food and Nutrition Committees, but there is a need to involve the multi-sectorial platform as it is an already functioning structure representing all government levels, from the ward level to the cabinet level.

\section{Working with existing or designing of multi-stakeholder partnerships (MSPs)}

MSPs may consist of different groups (private sector, civil society, government, education/research) who share a common problem or aspiration, while having different interests or 'stakes'. They can serve as a mechanism for groups to make decisions and take action for the common good at the local,

108 To ring-fence a grant or fund means to put restrictions on it, so that it can only be used for a particular purpose.

109 Interview with Mr. Washington Zhakata. Director Climate Change Management at the Ministry of Environment, Climate, Tourism and Hospitality Industry. Green climate finance focal point.

110 World Bank. 2016. Making Climate Finance Work in Agriculture. 
national or international scale. To be effective, however, such processes need to consider issues of power and conflict, systemic change and the social and cognitive paths involved in interaction and learning. Designing and facilitating MSPs can be challenging, therefore 7 principles have been identified that can help support this process towards healthy and effective partnerships:

1. Principle 1: Embrace systemic change.

2. Principle 2: Transform institutions

3. Principle 3: Work with power

4. Principle 4: Deal with conflict

5. Principle 5: Communicate effectively

6. Principle 6: Promote collaborative leadership

7. Principle 7: Foster participatory learning

Click here to access the MSP guide http://www.mspguide.org/sites/default/files/case/msp guide-2016-digital.pdf

\section{Capacity building across different policy levels}

Several key informants recommended strengthening capacities not only of local stakeholders at the district level, but also at higher policy levels and across the selected value chains:

- Need for strengthening capacities at the central Ministerial level/land/gender commission level on relevant policy topics such as climate, nutrition and gender mainstreaming. Also, closing the gap with the field and fostering exchange between policy levels.

- Need for strengthening capacities at districts levels of extension officers and VC actors: SHF, women's groups, youth groups, traditional leaders, etc.

- Foster participatory learning across value chain actors and between different policy levels by making use of social learning (see also principle 7 of the MSPs). By observing each other's behaviour, they will learn, build trust and increase their understanding of each other's realities.

- Example from ICRISAT: they have been working with innovation platforms in relation to value chain development. Here, different chain actors themselves collectively identify the challenges and come up with solutions. 


\section{Appendix 1 Conceptual linkages between climate and nutrition by IFPRI (2015)}

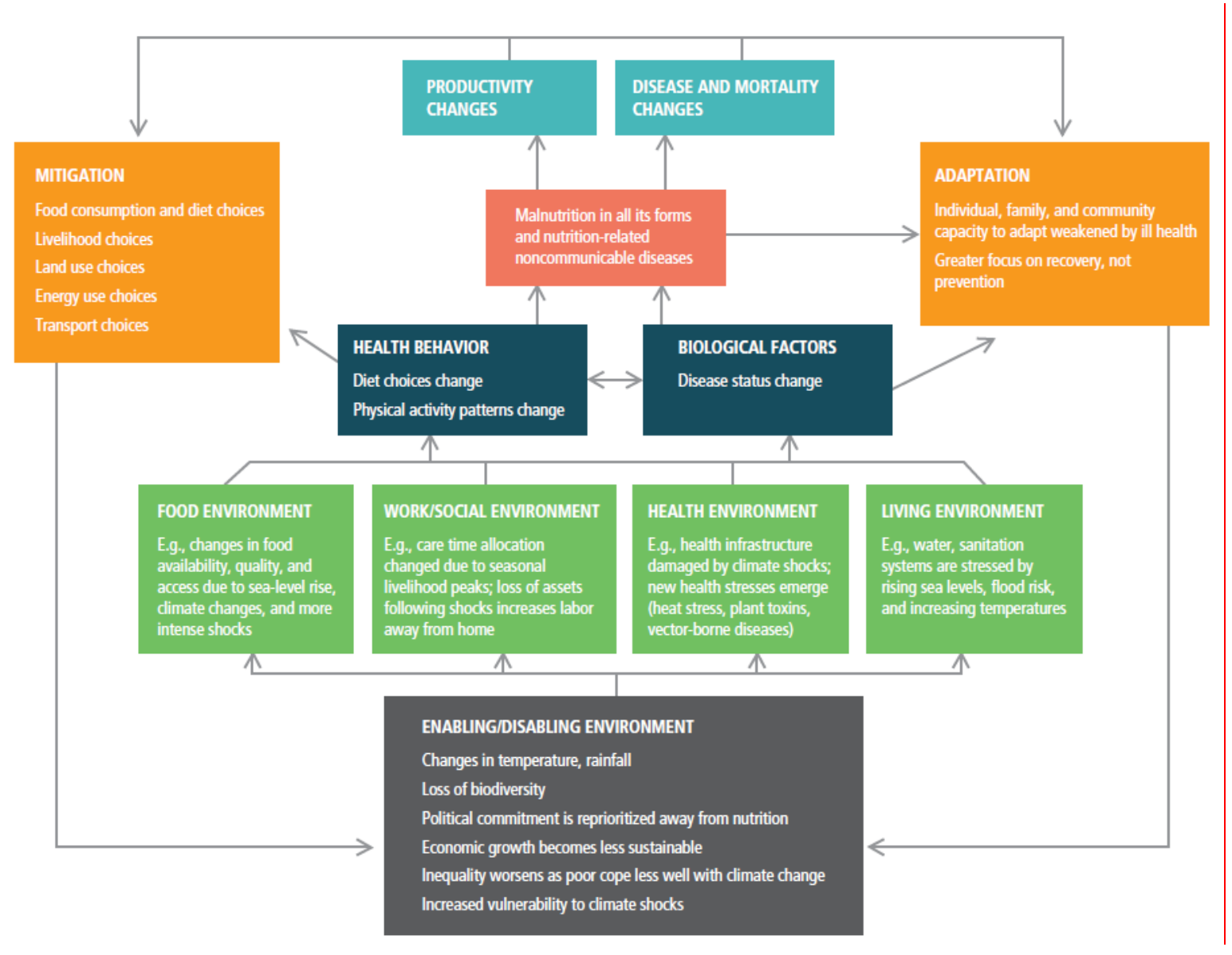




\section{Appendix 2 Food Systems Framework}

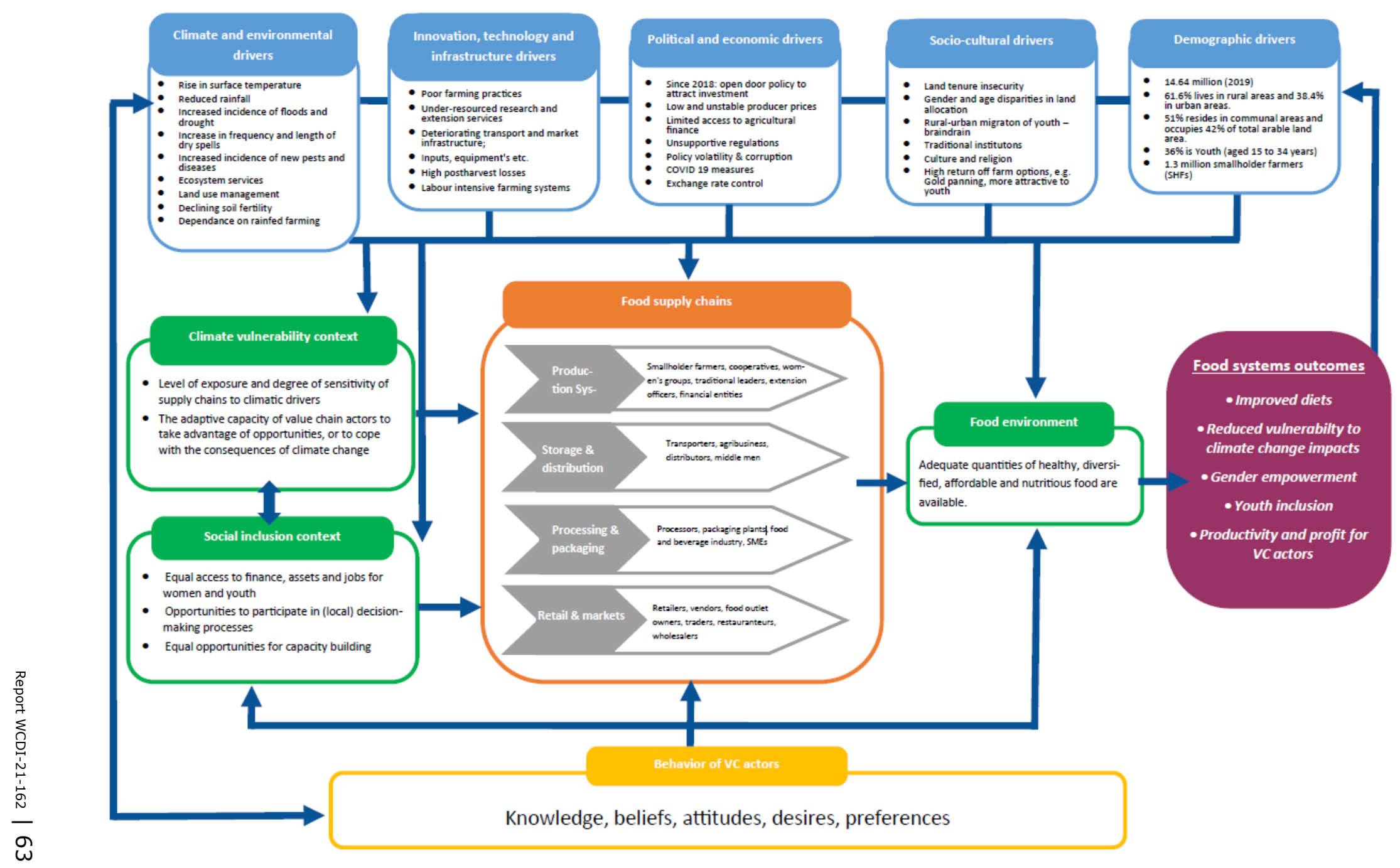




\section{Appendix 3 Value chain overview}

\begin{tabular}{|c|c|c|c|c|c|c|c|}
\hline & Type of value chain & $\begin{array}{l}\text { Recommended } \\
\text { in MAWRR CN }\end{array}$ & Nutrition considerations & Climate considerations & Gender considerations & Youth considerations & Further comments \\
\hline $\begin{array}{l}\text { Beans and } \\
\text { legumes }\end{array}$ & All beans & & $\begin{array}{l}\text { Good source of proteins (e.g. two } \\
\text { to three times more than cereals), } \\
\text { low fat content, rich in minerals } \\
\text { and B vitamins }\end{array}$ & $\begin{array}{l}\text { For beans in general: Fairly } \\
\text { widespread historical } \\
\text { suitability. Areas of good to } \\
\text { excellent suitability reduced } \\
\text { by mid-century. } \\
\text { Promote beans and legumes } \\
\text { within diversified, multi-crop } \\
\text { and intercrop combinations; } \\
\text { Research, develop and } \\
\text { promote locally-adapted and } \\
\text { drought-resilient varieties. }\end{array}$ & $\begin{array}{l}\text { Women are more involved in } \\
\text { bean and cowpeas than } \\
\text { soybean (again a colonial } \\
\text { legacy issue should be } \\
\text { considered where soybean was } \\
\text { regarded as a cash crop). Cash } \\
\text { crops have historically been } \\
\text { regarded as male preserve. } \\
\text { Cowpeas are lowly regarded, } \\
\text { does not require a lot of capital } \\
\text { but it is labour-intensive. Even } \\
\text { through, cowpeas mostly } \\
\text { grown for subsistence so } \\
\text { women can easily do that on a } \\
\text { small scale, not much finds its } \\
\text { way to markets. Cowpeas } \\
\text { value chain is an area that can } \\
\text { easily be promoted, women } \\
\text { who do not have access to } \\
\text { loans (needed in soybean } \\
\text { production) can easily start a } \\
\text { venture. But also provide more } \\
\text { options for value addition. } \\
\text { Provided women have access } \\
\text { to capital, soybean is an area } \\
\text { that provides more options for } \\
\text { value addition (making oil, } \\
\text { making bread, etc) so women } \\
\text { can be supported to grow }\end{array}$ & $\begin{array}{l}\text { Beans can have quick return } \\
\text { (sometimes within } 3 \text { months) } \\
\text { which attracts youth }\end{array}$ & \\
\hline
\end{tabular}




\begin{tabular}{|c|c|c|c|c|c|c|}
\hline & Type of value chain & $\begin{array}{l}\text { Recommended } \\
\text { in MAWRR CN }\end{array}$ & Nutrition considerations & Climate considerations & Youth considerations & Further comments \\
\hline & High iron beans & & $\begin{array}{l}\text { Fortified beans can make a } \\
\text { considerable contribution to } \\
\text { micronutrient (iron) intake - iron } \\
\text { deficiency still a widespread issue } \\
\text { in Zimbabwe }\end{array}$ & & Not common & \\
\hline & Soybeans & $\mathrm{x}$ & & & $\begin{array}{l}\text { Very few youths involved in } \\
\text { soybean cultivation. Those } \\
\text { involved are mostly at the } \\
\text { production level and a few at } \\
\text { the processing stage. Potential } \\
\text { for more to be involved } \\
\text { downstream of the value chain }\end{array}$ & $\begin{array}{l}\text { There is a good } \\
\text { market for legumes } \\
\text { such as beans and } \\
\text { cowpeas. Soyabean } \\
\text { value chain is more } \\
\text { for the well } \\
\text { mechanised farmers, } \\
\text { e.g. harvesting } \\
\text { requires combine } \\
\text { harvesters }\end{array}$ \\
\hline & Cowpea & & Rich source of folate & $\begin{array}{l}\text { Likely to become increasingly } \\
\text { marginal, with decreases } \\
\text { predicted for total spatial } \\
\text { area and suitability of the } \\
\text { crop by the Mid-Century } \\
\text { future. }\end{array}$ & $\begin{array}{l}\text { This is more of a subsistence } \\
\text { crop mainly grown for HH } \\
\text { consumption. Not attractive for } \\
\text { youths }\end{array}$ & \\
\hline & Mungbean & & Rich source of iron & & $\begin{array}{l}\text { Very lucrative and attractive, } \\
\text { youths will benefit if they get } \\
\text { involved }\end{array}$ & \\
\hline \multirow[t]{2}{*}{ Seeds } & & & $\begin{array}{l}\text { Rich source of fat, protein and } \\
\text { fibres }\end{array}$ & & & \\
\hline & Sesame & $\mathrm{x}$ & $\begin{array}{l}\text { Sesame seeds for nutrition. } \\
\text { People do not yet know how to } \\
\text { incorporate these into their diets. }\end{array}$ & & $\begin{array}{l}\text { Only common in some parts of } \\
\text { the country like Gokwe, Binga, } \\
\text { Nyaminyami with limited market } \\
\text { access. Youth can participate in } \\
\text { production mainly done under } \\
\text { contract farming. Otherwise its } \\
\text { not a common crop in other } \\
\text { parts of the country. }\end{array}$ & $\begin{array}{l}\text { Develop a niche } \\
\text { market and there is } \\
\text { a need for linking } \\
\text { farmers with a } \\
\text { sustainable market }\end{array}$ \\
\hline
\end{tabular}


Sunflower

Increasingly marginal.

Youths can participate more in

Depletes nutrients in the soil

and requires ample fertiliser

the processing of sunflower into

oil and sell cake to stockfeed

manufacturers or livestock

farmers
Nuts
Rich source of proteins

Some varieties do well in

semi-arid regions. Likely to

be comparatively better

adapted to Zimbabwe's

current and future climate

conditions than climate-

sensitive staples such as

maize. The future production

potential is likely to become

increasingly marginal and w

require ongoing technical

support and investments

across the value chain.
This is more complex. Cannot A lucrative value chain for

said to be just traditionally youths esp. the processing of

a female crop without

historicising it. When did

the nuts to produce peanut

groundnuts become female

crops? In colonial Zimbabwe,

maize, wheat, soybeans were

cash crops and male farmers

trained as master

owned land). So they

dominated cash crop

production. But women and

children provided the labour.

So then women were

relegated to inferior crops like

groundnuts. So perhaps it

could be a colonial legacy

more than tradition. The

legacy has seen women

dominating the growing and

selling of groundnuts, making

peanut butter and marketing

it. It is also dominated by

women because its less capital

intensive - does not require

much in terms of fertiliser

butter
There is a good

market for these

crops and also fetch

good prices on the

market 


\begin{tabular}{|c|c|c|c|c|c|c|c|}
\hline & Type of value chain & $\begin{array}{l}\text { Recommended } \\
\text { in MAWRR CN }\end{array}$ & Nutrition considerations & Climate considerations & Gender considerations & Youth considerations & Further comments \\
\hline & Bambara nut & & $\begin{array}{l}\text { High quality protein (rich in } \\
\text { methionine) }\end{array}$ & & & $\begin{array}{l}\text { Aggregation in rural areas and } \\
\text { transportation into towns }\end{array}$ & \\
\hline \multicolumn{8}{|l|}{ Staple } \\
\hline & Orange maize & & $\begin{array}{l}\text { Rich in pro-vitamin A. It has been } \\
\text { found that among some } \\
\text { communities, orange maize was } \\
\text { associated with food aid. There is } \\
\text { need to invest in marketing to } \\
\text { change consumer perception. } \\
\text { Can be processed into maize } \\
\text { meal, porridge, samp, and } \\
\text { fermented drink. }\end{array}$ & $\begin{array}{l}\text { Fairly widespread historically. } \\
\text { Area considered to be of } \\
\text { good-to-excellent suitability } \\
\text { will be considerably reduced } \\
\text { by Mid-Century. } \\
\text { Climate recommendation: } \\
\text { The risk of reduced } \\
\text { production of maize can be } \\
\text { partly offset by continued } \\
\text { promotion of crop } \\
\text { diversification, including } \\
\text { intercropping and multi-crop } \\
\text { approaches that include } \\
\text { diverse legumes and } \\
\text { alternative cereals such as } \\
\text { millet and sorghum. }\end{array}$ & & $\begin{array}{l}\text { High returns when sold as green } \\
\text { mealies - therefore attractive to } \\
\text { youths. Also youths can be } \\
\text { involved in direct buying of } \\
\text { grain from farmers for further } \\
\text { processing and marketing }\end{array}$ & \\
\hline Small grains & & & $\begin{array}{l}\text { Better nutritional values than } \\
\text { maize (when it comes to } \\
\text { micronutrients) }\end{array}$ & $\begin{array}{l}\text { Recommended to promote } \\
\text { access to locally appropriate } \\
\text { cultivars, in addition to } \\
\text { promoting the adoption of } \\
\text { alternative climate-resilient } \\
\text { cereals such as millet }\end{array}$ & $\begin{array}{l}\text { Women are involved in } \\
\text { production, but due to its } \\
\text { labour-intensive nature, the } \\
\text { area planted is not extensive. } \\
\text { It is an area that can be } \\
\text { promoted especially with } \\
\text { climate change because the } \\
\text { crops are drought-tolerant. } \\
\text { Women have low access to } \\
\text { irrigation, and even where } \\
\text { there is irrigation, women's } \\
\text { fields are watered last, so its } \\
\text { better to direct women to such } \\
\text { crops. But what is also critical } \\
\text { is market linkages, unlike } \\
\text { maize and other crops, the } \\
\text { market for these crops is not }\end{array}$ & & \\
\hline
\end{tabular}




\begin{tabular}{|c|c|c|c|c|c|c|c|}
\hline & Type of value chain & $\begin{array}{l}\text { Recommended } \\
\text { in MAWRR CN }\end{array}$ & Nutrition considerations & Climate considerations & Gender considerations & Youth considerations & Further comments \\
\hline & & & & & $\begin{array}{l}\text { well developed, partly because } \\
\text { Zimbabwe is a maize country, } \\
\text { but also the crops are } \\
\text { associated with } \\
\text { cultural/traditional celebrations } \\
\text { hence they may be regarded } \\
\text { as having no or less market } \\
\text { value. } \\
\text { Harvesting and processing of } \\
\text { these crops is labour-intensive. } \\
\text { For many smallholder farming } \\
\text { HH, labour demand is one of } \\
\text { main limiting factors for the } \\
\text { production of small grains. }\end{array}$ & & \\
\hline & Sorghum & & & $\begin{array}{l}\text { Marginal historical suitability. } \\
\text { Unsuitable by Mid-Century. } \\
\text { sorghum is likely to become } \\
\text { increasingly marginal and, in } \\
\text { some regions, wholly } \\
\text { unsuitable as a result of } \\
\text { climate change by Mid- } \\
\text { Century. }\end{array}$ & & $\begin{array}{l}\text { Youth participation in the } \\
\text { production of these traditional } \\
\text { crops is low. But there is room } \\
\text { for them to participate more by } \\
\text { offering threshing services (but } \\
\text { finance is needed to buy } \\
\text { threshers) }\end{array}$ & $\begin{array}{l}\text { Recommended to } \\
\text { invest in marketing } \\
\text { of cereal alternatives } \\
\text { to maize (including } \\
\text { advocacy towards } \\
\text { market-oriented } \\
\text { pricing to improve } \\
\text { farmers perception } \\
\text { of the crop). } \\
\text { UNDP has conducted } \\
\text { a barrier analysis for } \\
\text { small grains value } \\
\text { chains in } 2018\end{array}$ \\
\hline & Finger millet & & $\begin{array}{l}\text { High in calcium, iron, dietary } \\
\text { fibre, and B vitamins }\end{array}$ & \multirow{2}{*}{$\begin{array}{l}\text { Good to excellent, } \\
\text { widespread historical } \\
\text { suitability. Minor } \\
\text { deterioration from 'excellent' } \\
\text { to 'good' across most areas }\end{array}$} & & & \\
\hline & Pearl millet & & Idem & & & & \\
\hline Livestock & & & $\begin{array}{l}\text { Animal-source foods are } \\
\text { nutritionally critical, especially for } \\
\text { those most vulnerable to } \\
\text { malnutrition. They provide protein } \\
\text { and micronutrients such as iron, }\end{array}$ & $\begin{array}{l}\text { Increased temperatures, } \\
\text { increased heat stress and } \\
\text { reduced water availability are } \\
\text { expected to adversely affect } \\
\text { livestock production and }\end{array}$ & & & \\
\hline
\end{tabular}


zinc, calcium, and B vitamins that productivity as well as

are often lacking in other dietary health. CC will also affect the

sources.

quality and quantity of

Rarely slaughtered for household fodder.

consumption

Women generally own or

control less when it comes to

cattle. This is partly based on

culture and tradition of male

payment of bride price

(lobola). So that is used as a

justification for not

encouraging women's

ownership of cattle

Secondly, development

interventions, for instance, in

beef production by the state

have also followed the

patriarchal model that has long

seen males targeted for

livestock (cattle) production -

cattle ranching as a male

domain. Command Livestock

farming under Command

agriculture was silent on

gender.

Cattle production as a business

is capital intensive; if women

do not have access to finance,

they are likely to be excluded.

Need gender targeting where

female headed households are

deliberately targeted or

women in male headed

households. Also robust

gender sensitisation, with

traditional leaders as entry

points (considered custodians

of cultures) because they also
Well defined and more stable lue chain that requires high capital thereby restricting entry by youths. Otherwise given resources, this is a profitable and attractive value chain for everyone, including youths. 


\begin{tabular}{|c|c|c|c|c|c|c|c|}
\hline & Type of value chain & $\begin{array}{l}\text { Recommended } \\
\text { in MAWRR CN }\end{array}$ & Nutrition considerations & Climate considerations & Gender considerations & Youth considerations & Further comments \\
\hline & & & & & $\begin{array}{l}\text { promote male bias when it } \\
\text { comes to cattle ownership by } \\
\text { men as part of tradition. } \\
\text { Also target state agencies so } \\
\text { that they promote women in } \\
\text { cattle ranching. }\end{array}$ & & \\
\hline & Small ruminants & $\mathrm{x}$ & \multirow{3}{*}{$\begin{array}{l}\text { Good source of protein as these } \\
\text { are regularly slaughtered for } \\
\text { household consumption }\end{array}$} & & & & \\
\hline & Chicken & & & & & $\begin{array}{l}\text { A lot of people are flocking into } \\
\text { this value chain because it is } \\
\text { less capital intensive, youths } \\
\text { can partake at every stage of } \\
\text { this value chain. Local market } \\
\text { for slaughter stock still not well } \\
\text { defined, but there is high } \\
\text { demand for breeding stock. } \\
\text { Youth can partake in } \\
\text { aggregation for export market. } \\
\text { Potential for youths to venture } \\
\text { into processing stages of this } \\
\text { value chain to produce different } \\
\text { meat products - -- capacity } \\
\text { building and financial resources } \\
\text { needed. }\end{array}$ & $\begin{array}{l}\text { Niche market for } \\
\text { organic products }\end{array}$ \\
\hline & Rabbits & & & & & & Niche market \\
\hline \multirow[t]{4}{*}{$\begin{array}{l}\text { Horticulture - } \\
\text { exotic } \\
\text { vegetables }\end{array}$} & & & $\begin{array}{l}\text { Increase dietary } \\
\text { diversity }\end{array}$ & $\begin{array}{l}\text { Not drought-resistant and } \\
\text { require irrigation equipment }\end{array}$ & $\begin{array}{l}\text { Women participate in all three } \\
\text { domains. They grow and } \\
\text { market exotic and indigenous } \\
\text { vegetables on a large scale }\end{array}$ & $\begin{array}{l}\text { Good opportunity for value } \\
\text { addition, e.g. dried vegetables }\end{array}$ & $\begin{array}{l}\text { There is a good } \\
\text { market, but farmers } \\
\text { need knowledge on } \\
\text { managing supply } \\
\text { and demand }\end{array}$ \\
\hline & Tomatoes & $x$ & \multirow{3}{*}{$\begin{array}{l}\text { Tomatoes and onion consumption } \\
\text { is already widespread in } \\
\text { Zimbabwe and the nutritional } \\
\text { value of these crops is relatively } \\
\text { low, compared to other } \\
\text { vegetables. For improved } \\
\text { nutrition, it is recommended to } \\
\text { focus on other crops (see }\end{array}$} & $\begin{array}{l}\text { Expected to undergo an } 80 \% \\
\text { reduction in total spatial area } \\
\text { suitable for production, but a } \\
\text { small increase in productivity }\end{array}$ & & $\begin{array}{l}\text { Youths are involved in all stages } \\
\text { of this value chain. But there is } \\
\text { room for more youths to } \\
\text { participate in the processing } \\
\text { stages such as making tomato } \\
\text { powder, paste, purees, etc. }\end{array}$ & \\
\hline & Onion & $x$ & & & & Production, aggregation, value & \\
\hline & Potatoes & $x$ & & & & addition (powder, canned, etc.), & \\
\hline
\end{tabular}




\section{Type of value chain}

Recommended Nutrition considerations

Climate considerations

Gender considerations

ror

Horticulture -

fruits
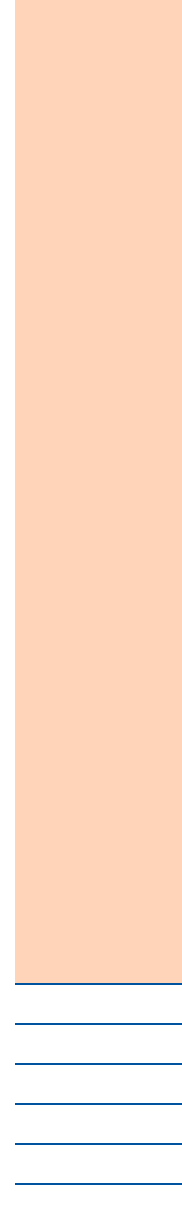

horticulture - fruits and

indigenous vegetables)

$\mathrm{x} \quad$ Increase dietary diversity

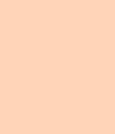

$\begin{array}{lll}\text { Avocado } & \mathrm{x} & \text { High in unsaturated } \\ \text { Mango } & \mathrm{x} & \text { High in vitamin } \mathrm{A}\end{array}$

\section{in MAWRR C}

sity

Not drought-tolerant and are
specific to certain climatic
regions

\section{market ex
vegetables.
But there}

with fruits. Women participate

in harvesting and marketing of

fruits. In a communal set up

for instance, because of

patrilocality (women move to

husband's residence after

marriage), they do not own

land and trees there. They can

harvest fruits and market e.g.

mangoes, bananas or apples,

but it is common for men to

say 'my land, my trees' hence

disempowering women.

It is problematic then to

promote fruit value chains for

women without addressing

ownership and control issues

around the fruit trees.

Otherwise it is a lucrative

value chain, with opportunities

for value addition but should

be coupled with market

linkages

transportation and marketing

are the areas in which youths

can be involved.

Good opportunity for value

Can link up with

ZIMTRADE for

markets, both local

and export markets

inges

fruits, fruit juice, canned fruits, etc. 


\begin{tabular}{|c|c|c|c|c|c|c|c|}
\hline & Type of value chain & $\begin{array}{l}\text { Recommended } \\
\text { in MAWRR CN }\end{array}$ & Nutrition considerations & Climate considerations & Gender considerations & Youth considerations & Further comments \\
\hline \multirow[t]{4}{*}{$\begin{array}{l}\text { Horticulture - } \\
\text { indigenous } \\
\text { vegetables }\end{array}$} & & & $\begin{array}{l}\text { Indigenous vegetables are a } \\
\text { source of nutrients to } \\
\text { communities. Many indigenous } \\
\text { vegetables are characterised by a } \\
\text { high nutritional value compared } \\
\text { with global exotic vegetables and } \\
\text { have high values of proteins, } \\
\text { calcium, iron, vitamin A, C, folic } \\
\text { acids and phenolic compounds. }\end{array}$ & $\begin{array}{l}\text { Seem to be drought-tolerant, } \\
\text { though more research is } \\
\text { needed }\end{array}$ & $\begin{array}{l}\text { Leafy vegetables are } \\
\text { consumed in most households } \\
\text { and it is women who handle } \\
\text { food preparation. Besides } \\
\text { doing the marketing of green } \\
\text { vegetables, women also do the } \\
\text { mundane - drying and selling } \\
\text { of vegetables - considered as } \\
\text { female roles. Interventions to } \\
\text { reduce the time and labour } \\
\text { burdens on women (e.g. the } \\
\text { drying process) should be } \\
\text { considered. }\end{array}$ & $\begin{array}{l}\text { Good value addition } \\
\text { opportunities to attract youth } \\
\text { participation }\end{array}$ & $\begin{array}{l}\text { Issues with } \\
\text { propagation, seeds } \\
\text { only sprout in season }\end{array}$ \\
\hline & Amaranth (mowa) & & & & & \multirow{3}{*}{$\begin{array}{l}\text { These are seasonal crops and } \\
\text { their availability depend on the } \\
\text { rains, this makes them less } \\
\text { attractive to youths. But where } \\
\text { possible, youths can aggregate } \\
\text { and further process and } \\
\text { package them for easy } \\
\text { marketing }\end{array}$} & \\
\hline & Spider leaf/vegetable (Nyeve) & & & & & & \\
\hline & Blackjack (mutsine) & & & & & & \\
\hline \multirow[t]{7}{*}{ Cash crops } & & & $\begin{array}{l}\text { Contribution to nutrition (almost) } \\
\text { solely through income pathways }\end{array}$ & & & & \\
\hline & Tea & $x$ & & & \multirow{6}{*}{$\begin{array}{l}\text { The mere fact that these are } \\
\text { cash crops, the general } \\
\text { perception is that they are } \\
\text { controlled by men; it's a male } \\
\text { domain, while women provide } \\
\text { labour and marketing. We } \\
\text { have not gone past the } \\
\text { colonial hangover that coupled } \\
\text { cash crops with men, and } \\
\text { women and children as } \\
\text { labourers }\end{array}$} & $\begin{array}{l}\text { Tea and Coffee - we have a few } \\
\text { youths that are into processing } \\
\text { and exporting to East Africa, } \\
\text { more youths can participate in }\end{array}$ & $\begin{array}{l}\text { Highly } \\
\text { commercialised and } \\
\text { mechanised value } \\
\text { chains } \\
\end{array}$ \\
\hline & Coffee & $x$ & & & & & \\
\hline & Macadamia nuts & $\mathrm{x}$ & & & & & \\
\hline & Timber & $x$ & & & & & \\
\hline & Hay & $x$ & & & & $\begin{array}{l}\text { Government plans to train youth } \\
\text { in bale making }\end{array}$ & \\
\hline & Cotton & & & & & $\begin{array}{l}\text { Mainly involved in primary } \\
\text { production. Some are involved } \\
\text { in the oil extraction and there is }\end{array}$ & \\
\hline
\end{tabular}




\begin{tabular}{|c|c|c|c|c|c|c|c|}
\hline & Type of value chain & $\begin{array}{l}\text { Recommended } \\
\text { in MAWRR CN }\end{array}$ & Nutrition considerations & Climate considerations & Gender considerations & Youth considerations & Further comments \\
\hline & & & & & & $\begin{array}{l}\text { a potential to have more } \\
\text { involvement from youths in this } \\
\text { activity }\end{array}$ & \\
\hline \multirow[t]{3}{*}{ Edible Insects } & & & $\begin{array}{l}\text { Insects are rich in protein } \\
\text { (ranging between } 52-70 \% \text { ) and } \\
\text { micronutrients (iron: } 24.2-52.9 \\
\mathrm{mg} / 100 \mathrm{~g} \text { ) and zinc content: } \\
10.0-20.9 \mathrm{mg} / 100 \mathrm{~g} \text { ) with } \\
\text { intervention studies showing that } \\
\text { their consumption improves } \\
\text { nutrition. Insect consumption is a } \\
\text { common practice among rural and } \\
\text { urban Zimbabweans. }\end{array}$ & Found in dry regions & $\begin{array}{l}\text { High participation of women in } \\
\text { the value chain. Edible insects } \\
\text { such as mopane worms } \\
\text { (Imbrasia belina) have been } \\
\text { identified by ILO Zimbabwe to } \\
\text { have great potential for female } \\
\text { economic empowerment } \\
\text { ventures. }\end{array}$ & & $\begin{array}{l}\text { There is a readily } \\
\text { available urban and } \\
\text { rural market and } \\
\text { many value addition } \\
\text { opportunities. There } \\
\text { is a need for } \\
\text { supporting policies to } \\
\text { promote this value } \\
\text { chain }\end{array}$ \\
\hline & Mupane worm & & & & & \multirow[b]{2}{*}{$\begin{array}{l}\text { In areas where these are } \\
\text { present, youths actively } \\
\text { participate in the harvesting } \\
\text { process. But there is a potential } \\
\text { for them to participate in other } \\
\text { downstream activities such as } \\
\text { grinding these insects to } \\
\text { produce powder used in cooking } \\
\text { and baking. }\end{array}$} & \\
\hline & Harurwa & & & & & & \\
\hline
\end{tabular}




\section{Appendix 4 List of interviewees}

\begin{tabular}{|c|c|c|c|}
\hline Name & Area of expertise & Topic & $\begin{array}{l}\text { Date of } \\
\text { interview }\end{array}$ \\
\hline $\begin{array}{l}\text { Janaa Keitaanranta \& } \\
\text { Joylyn Ndoro }\end{array}$ & $\begin{array}{l}\text { IFAD Country Director } \\
\text { Zimbabwe }\end{array}$ & IFAD programmes in Zimbabwe: SACP, SIRP & $21-04-2020$ \\
\hline Dr George Kembo & $\begin{array}{l}\text { Director, Food and } \\
\text { Nutrition Council }\end{array}$ & $\begin{array}{l}\text { Nutrition, multisectoral nutrition governance } \\
\text { (incl. climate) }\end{array}$ & $22-04-2020$ \\
\hline Hilton Mbozi & Oxfam Zimbabwe & $\begin{array}{l}\text { SHF, female empowerment, ag extensions, } \\
\text { farmer field schools, breeding climate- } \\
\text { resilient varieties }\end{array}$ & $22-04-2020$ \\
\hline Sakile Kudita & $\begin{array}{l}\text { Country Manager, } \\
\text { HarvestPlus }\end{array}$ & $\begin{array}{l}\text { Biofortification and value chain development } \\
\text { (gender and youth inclusion, challenges and } \\
\text { tips) } \\
\text { Markets and SH commercialisation }\end{array}$ & $23-04-2020$ \\
\hline Dr Conrad Zawe & $\begin{array}{l}\text { Director, Department of } \\
\text { Irrigation }\end{array}$ & $\begin{array}{l}\text { Role of irrigation in CSA. Nutrition as a } \\
\text { criteria crop selection. }\end{array}$ & $23-04-202$ \\
\hline Delilah Takawira & Nutritionist, FAO & $\begin{array}{l}\text { Promoting biofortification, value chains, } \\
\text { markets, care group model (gender and } \\
\text { youth). Food consumption patterns and } \\
\text { trends (WHY) }\end{array}$ & $23-04-2020$ \\
\hline Mr Bernard Mache & Director, AGRITEX & $\begin{array}{l}\text { Capacity building in ag extension systems, } \\
\text { integration of climate and nutrition in training } \\
\text { programmes } \\
\text { The role of the private sector in agricultural } \\
\text { extension }\end{array}$ & $22-04-2020$ \\
\hline Dr Martin Moyo & $\begin{array}{l}\text { Country Director, } \\
\text { ICRISAT }\end{array}$ & $\begin{array}{l}\text { Climate-smart technologies for SHF. How is } \\
\text { nutrition addressed? }\end{array}$ & $22-04-2020$ \\
\hline Dr. Sandra Bhatasara & $\begin{array}{l}\text { University of Zimbabwe } \\
\text { - Sociology department }\end{array}$ & $\begin{array}{l}\text { Gender inequality, gender politics, youth } \\
\text { inclusion in food VC }\end{array}$ & $29-04-2020$ \\
\hline Mr Clophas Ncube & $\begin{array}{l}\text { FAO Green Jobs for } \\
\text { Youths Project }\end{array}$ & $\begin{array}{l}\text { Youth inclusion. Implementation mechanisms } \\
\text { (selection, support developing of BP, grants). } \\
\text { Collaboration MoA. }\end{array}$ & $30-04-2020$ \\
\hline Mr Washington Zhakata & $\begin{array}{l}\text { Climate Change } \\
\text { department }\end{array}$ & $\begin{array}{l}\text { Climate adaptation and mitigation measure } \\
\text { currently promoted. } \\
\text { Climate governance. }\end{array}$ & $23-04-2020$ \\
\hline
\end{tabular}




\section{Appendix 5 Interview guide}

\section{Questions related to Nutrition-sensitive value chain}

a. Who, according to you, are vulnerable groups for malnutrition? Why?

b. What are the underlying causes of malnutrition in Zimbabwe?

c. How would you explain the current food consumption patterns and main dietary gaps? insert based on ZimVac, ZDHS, and MICS\}

d. Do you know of any nutrition-sensitive value chains programmes implemented or currently being implemented in Zimbabwe?

i. What value chains are these and through which programmes are they (being) implemented?

ii. Do you think these nutrition-sensitive value chains are climate sensitive or at least incorporate an element of climate adaptation?

iii. In your opinion, what are the opportunities and challenges for integrating nutrition into smart climate value chains?

e. Is there a policy(-ies) in Zimbabwe that promote(s) the integration of nutrition into all climatesmart value chain programmes being implemented in Zimbabwe?

i. At which stage of the value chain (crop production --> harvesting --> processing --> consumption) can nutrition issues be introduced?

\section{Questions related to Market-oriented value chains}

a. What strategies and challenges exist to target smallholders in value chain development?

b. What is the importance of aiming for inclusive value chains?

c. What challenges exist when smallholder farmers want to start commercialising their crops? Any recommendations to tackle this?

d. What institutional challenges to the promotion of commercialisation exist among smallholders?

e. Any ideas to promote entrepreneurship among value chain stakeholders?

\section{Questions related to Climate-smart value chains}

a. Which crops are most vulnerable vs most resilient to climate change impacts? (current and over 20yrs)

b. Are these climate-smart and nutrition-sensitive value chains? How is the nutrition component integrated and what are the challenges, if any?

c. Which regions/agro-ecological areas are most vulnerable to climate change impacts?

d. What are (common) and effective CSA technologies for smallholders?

- Crop-specific?

- Each different part of the VC?

e. What are challenges related to the adoption of CSA technologies (lack of resources, skills, knowledge, attitude, etc.)?

- At the smallholder level

- At the institutional level (e.g. policies/extension services)

f. What are suitable agriculture commodities for climate-smart smallholder commercialisation (taking Corona into account?) and why?

g. How would you describe/define climate-smart value chains in Zimbabwe?

h. What are challenges when promoting climate-smart value chains in Zimbabwe?

i. What are common/effectives examples of 'Climate Proofed Value Chain Infrastructure'?

j. What are the challenges to design/construction/maintenance/funding of 'Climate Proofed Value Chain Infrastructure?

k. Which value chains are associated with unsustainable fuel use (fuelwood, leading to forest degradation, water and air pollution)?

I. Do you have recommendations for contributing to value chain development, while minimising GHG emissions? ('green processing/transport technologies) 
m. Is there sufficient and reliable climate data available for Zimbabwe? How does climate data currently reach VC stakeholders?

n. What are the key priorities/needs to increase the adaptive capacity of smallholders? Are there gender/age differences?

o. How does the department of Climate collaborate with the Ministry of Agriculture at the grassroot level?

p. Is the government/Are the ministries tapping into opportunities for accessing Climate finance? If so, what funds? If not, why not?

q. Could the irrigation schemes currently promoted by the government be considered climatesmart?

\section{Questions related to Inclusive value chains}

a. Regarding smallholder farmers, who often own the land (in terms of gender)? And to what extent do women have a role in the decision-making process regarding land issues?

b. Problems with youth/gender in VC development?

c. In which parts of the agricultural value chains do women play bigger roles (visible/invisible) and why?

d. In which parts of the agricultural value chains do youth (18-35) play bigger roles/have a preference to work in (visible/invisible) and why?

e. What could be some effective ways to target rural women/youth if they don't own land?

f. What kind of effective and innovative examples do you have of female empowerment in agricultural value chain development (peer support, senior junior support, women care groups)?

g. Are you familiar with situations where it is not women, but men who need to be empowered in agricultural value chain development?

h. What kind of effective and innovative examples do you have of youth engagement in agricultural value chain development?

i. In terms of gender, ethnicity and age, who are the most vulnerable to climate change impacts and why?

j. Main lessons learned from this FAO - green jobs project?

k. What are the opportunities for IFAD to contribute to youth inclusion in Zimbabwe and thus to support FAOs work as well? (prevent doing the same)?

I. How do you ensure youth involvement right from the planning phase of such a project?

\section{Implementation arrangements}

a. What type of institutions or multi stakeholder partnerships are in place to address climate and/or nutrition?

b. Lessons learned from other programmes 


\section{Appendix 6 Terms of Reference - Assignment}

Subject: Terms of Reference for the Pre-Design Study mission to Zimbabwe on 'Climate adaptation and mitigation measures for nutrition co-benefits in IFAD investments' (20 April - 31 September 2020)

\section{Background}

1. Climate change and food and nutrition security are strongly interlinked. First, increased evidence shows that climate impacts affect nutrition by influencing food production systems, e.g. through physiological effects on crops or changes in water and soil resources, but also by facing increased weed and pest challenges, or changes in the interplay between pathogens and livestock. Water systems and their management and sanitation environments are being stressed by rising sea levels, flood risks and/or increasing temperatures and with them the risk for vector-borne diseases, like dengue. This has an impact on livelihood choices, labour options and time allocated for caregiving and other nutrition-related activities. Therefore, climate change undermines current efforts to reduce hunger and promote nutrition. It is estimated that in all regions where stunting is already severe, climate change will increase stunting by 30-50 percent by 2050 .

2. Food production in its turn influence climate change. Systems of food production release greenhouse gases (e.g., carbon dioxide, methane, and nitrous oxide) into the atmosphere directly and drive land use change that releases additional carbon dioxide when forests are cleared, wetlands drained, and soils are tilled. Food production is a prime source of methane, and nitrous oxide, which have 56 times and 280 times the global warming potential (over 20 years) of carbon dioxide, respectively. Methane is produced during digestion in ruminant livestock, such as cows and sheep, or during anaerobic decomposition of organic material in flooded rice paddies. Nitrous oxide mainly arises from soil microbes in croplands and pastures and is affected by soil fertility management, such as fertiliser application ${ }^{111}$.

\section{Justification for the mission}

3. Against this background, IFAD designed a project tackling the adoption of climate adaptation measures, which increase nutrition co-benefits for smallholder farmers and their families. The project is titled 'Climate change and nutrition in value chain development' and it is funded under ASAP 2 (Adaptation for Smallholder Agriculture Programme - Phase II) and was approved in a memo signed on 6 August 2019. The project aims to develop a well-proven methodology and approach to support project designs/mid-term reviews and to strengthen the capacity of IFAD teams to conduct comprehensive and integrated assessments at project design that allow for the identification of adaptation and mitigation actions, while also reducing nutrition risks of food value chain investments.

4. In order to implement most of the activities of the above initiative, the provision of high quality technical support has been requested by IFAD from the Wageningen Centre for Development Innovation (WCDI). WCDI support will allow IFAD to develop an integrated approach for designing climate-smart and nutrition-sensitive value chains, hereby contributing to the operationalisation of IFAD's transformational framework for mainstreaming themes and to reinforce capacities of local actors.

5. This technical support provided by WCDI includes the three pre-design studies for three projects, in three IFAD supported countries, namely:

- Project on Regeneration of Livelihoods Landscapes (P-ROLL) in Lesotho

- Climate Smart Smallholder Value Chain Project (SVCP) in Vietnam

- Smallholder Agriculture Cluster Project (SACP) in Zimbabwe

111 Food in the Anthropocene: the EAT-Lancet Commission on healthy diets from sustainable food systems, The Lancet Commissions, February 2019. 
6. The pre-design study for Zimbabwe is planned in line with the planning scheduled for the full design of SACP.

\section{Main objective of the mission:}

7. To conduct a pre-design study mission for Zimbabwe with the aim of exploring opportunities for climate adaptation and mitigation and nutrition actions for future IFAD investments in Zimbabwe (forthcoming: SACP). Because of the COVID-19 crisis, this mission will be conducted in two parts; the first part is the literature review for Zimbabwe and remote interviews with selected key stakeholders and the second part a one-week mission (when the situation permits) to do field visits and conduct a validation workshop on the pre-design study findings.

\section{Specific Objectives of the mission:}

8. For the first part (20 April - 2 May)

- Based on the lessons learned from the literature review, explore which of the lessons learned can be applied in the Zimbabwe context;

- Consult with selected key stakeholders to describe the present climate adaption and mitigation and nutrition landscape, including the targeting of vulnerable groups and stakeholder involvement;

- Formulate appropriate pathways and suitable, sustainable, significant actions that effectively integrate climate mitigation and adaptation measures to maximise nutrition in IFAD's investments (including strategies, processes and/or methodologies if appropriate) that are capable of enriching IFAD's project designs with climate-nutrition linkages;

- To suggest feasible and concrete actions that can the be incorporated into the full design of SACP and flesh it out further

\section{At a later date:}

- Conduct field visits to understand the present living condition of the rural poor and other IFAD target groups and visit IFAD support projects;

- Validate the findings from the study mission in a national-level stakeholder workshop to learn from each other and build consensus.

\section{Deliverables:}

9. The mission deliverables include:

a. A pre-design study mission report for Zimbabwe where the application of lessons from the literature for the Zimbabwe context are discussed; the document also describes the stakeholder landscape, possible pathways for effectively integrating climate mitigation and adaptation measures to maximise nutrition and recommendations for target groups and opportunities for IFAD's future which are validated by the stakeholders; the report includes feasible and concrete potential interventions for the SACP project in Zimbabwe to consider, ordered as Must Dos, Can Dos and Maybe Dos.

b. A power point presentation (or more, as needed) to be presented during the briefing meeting with the design team.

c. A multi-sectoral stakeholder consultation workshop to discuss the preliminary findings in Zimbabwe with the objective of (i) validating the recommendations and interventions proposed, (ii) creating awareness through integrated approaches and linkages between the mainstreaming themes of key stakeholders. Participants will involve different sectors such as agriculture, environment and climate, health and nutrition, gender and youth, among others; they will include representatives from the government agencies, UN, NGOs, research organisations, private sectors. (postponed to a later date)

\section{Mission members:}

\section{Internationals in the Netherlands}

- Ilse Hennemann, Advisor Environmental Governance \& Climate Change, WCDI

- Sanne Bakker, Advisor Food and Nutrition Security, WCDI 


\section{Local consultants}

- Justice Nyamangara, Consultant Climate and Agriculture

- Lesley Macheka, Consultant Food and Nutrition

Counterpart Zimbabwe: Ministry of Lands, Agriculture, Water and Rural Resettlement

Duration of the mission: First part of the mission: 10 days (20 April - 2 May)

Second part of the mission: 7 days (to be determined) 


\section{Appendix 7 Analysis of stakeholders and nutrition actions relevant for SACP}

In a value chain project, such as $\mathrm{SACP}^{112}$, interventions aim to increase marketed agricultural output and, as a result, beneficiary income. In principle, the increase in income could lead to dietary improvements in the household by enabling the purchase of more nutritious and diverse foods, as well as to improvements to healthcare access, better water and sanitation, and better education. However, evidence shows that dietary and other improvements do not happen automatically with increases in income. In fact, there are a number of factors, especially low nutrition awareness and women's social status, that can prevent increases in income from leading to improvements in nutrition. Research shows that income generation is essential, but not sufficient, to improving nutrition outcomes-in fact it can have a positive, negative, or neutral effect on nutrition for beneficiaries or clients of agricultural projects $^{113}$. Therefore, to ensure that an increase in income leads to improvements in nutrition, it is fundamental to complement any income generation activities with specific actions to raise the target population's nutrition awareness and stimulate its consumption of nutritious foods and, most likely, increase the empowerment of women as well. For these specific actions, the SACP project can collaborate with partners that are already providing these services and benefit from their experiences, expertise and established implementation structures.

The Project design team has already identified a list of strategic partners to support the IFAD mainstreaming agenda which are described in the SECAP ${ }^{114}$. These partners are similar to those identified during the interviews conducted as part of the pre-design study. In addition to the list of partners identified by the design team, the pre-design study recommends exploring partnership opportunities with:

- Oxfam Zimbabwe, given their longstanding experience with the GALS methodology. The GALS methodology was developed by Oxfam, and is used by several organisations in Zimbabwe. Also, their $\mathrm{SD}=\mathrm{HS}$ programme focuses on farmer field schools for women, and includes participatory breeding of traditional nutritious and climate-resilient varieties, e.g. of sorghum and pear millet (relevant for cluster 1 focusing on traditional grain varieties and cluster 7 focusing on sorghum and pearl millet), as well as nutrition. They could be a strategic partner for the implementation (and curriculum building) of farmer field schools integrating climate and nutrition.

- ADRA, as this NGO is already working on female empowerment interventions in food value chain development through establishment of farmer market groups in Matobo district and Goromonzi (SACP) district.

In addition to that, the predesign study reviewed the stakeholders and nutrition action mapping, conducted by the REACH project ${ }^{115}$. This stakeholder mapping was organised around the core nutrition action, based on the focus areas of the national nutrition plan for Zimbabwe. The mapping included 19 districts. Overlap between this mapping and the districts selected for SACP is limited to two districts: Mbire and Tsholotsho district.

The following overview is a selection of core nutrition actions and stakeholders which are most relevant for the nutrition mainstreaming interventions envisioned for SACP (nutrition-sensitive value chains, female empowerment and nutrition education). The table includes a column with the stakeholders that are currently involved in coordination, technical support, monitoring \& evaluation, and capacity building of these core nutrition actions, including the field implementers (in bold). The last two columns present the coverage of these actions in the two overlapping districts of Mbire and Tsholotsho.

\footnotetext{
112 The SACP project will target smallholder farmers and agricultural producer groups (primary target group), and agriculture and food sector agribusiness owners, employees, and associated family members (secondary target group).

113 World Bank. 2007. From Agriculture to Nutrition: Pathways, Synergies and Outcomes.

114 This list includes Agritex, MoHCC, Harvest Plus, ZAGP, UNICEF, ICRISAT, Econet Wireless, ILO, NORAD.

115 REACH. 2018. Zimbabwe stakeholder and nutrition action mapping.
} 


\begin{tabular}{|c|c|c|c|c|c|}
\hline $\begin{array}{l}\text { Core nutrition actions } \\
\text { Thematic area } 2 \text { NNP }\end{array}$ & Target group & Link to SACP & Potential partners/Catalysts (field implementers in bold) & $\begin{array}{l}\text { Mbire } \\
\text { coverage }\end{array}$ & $\begin{array}{l}\text { Tsholotsho } \\
\text { coverage }\end{array}$ \\
\hline $\begin{array}{l}\text { Provide inputs to adopt } \\
\text { low input gardens. }\end{array}$ & $\begin{array}{l}\text { Number of smallholder farming } \\
\text { households provided with } \\
\text { inputs to promote low input } \\
\text { gardens }\end{array}$ & $\begin{array}{l}\text { Link to APGs to reach SHF and include } \\
\text { low input/backyard gardens for HH } \\
\text { nutrition in the training/activities for } \\
\text { APGs }\end{array}$ & $\begin{array}{l}\text { MLAWRR, CARITAS, Carbon Green Africa, CC, ENSURE(WVZ), Farmers Association } \\
\text { of Investment Group Trust, INSPIRE, IRCS, Lower Guruve Development } \\
\text { Association, Member of Parliament, MLAWRR, Plan International }\end{array}$ & $3.7 \%$ & $1.8 \%$ \\
\hline \multirow{3}{*}{$\begin{array}{l}\text { Provide nutrition } \\
\text { education on diversified } \\
\text { nutrient-rich foods (all } \\
\text { food groups including } \\
\text { plant and animal protein, } \\
\text { small grains, vegetables, } \\
\text { fruits) }\end{array}$} & $\begin{array}{l}\text { Number of pregnant women } \\
\text { provided nutrition education on } \\
\text { diversified nutrient-rich foods }\end{array}$ & $\begin{array}{l}\text { The outcome indicator for nutrition } \\
\text { included in SACP is MDD-W. This } \\
\text { action is important for improvements } \\
\text { to MDD-W. }\end{array}$ & & & \\
\hline & & $\begin{array}{l}\text { However, it is important that nutrition } \\
\text { education on dietary diversification } \\
\text { also reaches non-pregnant or } \\
\text { lactating women. Women AGPs could } \\
\text { be a platform for that. Partners with } \\
\text { these catalysts to scale up nutrition } \\
\text { education, to promote use of income } \\
\text { for nutrition. }\end{array}$ & $\begin{array}{l}\text { ENTERPRIZE, ENSURE(WVZ), Goal Zimbabwe, Hilfe zur Selbshilfe Help. Germany, } \\
\text { INSPIRE, MLAWRR, MoHCC, MWAGCD, Oxford Committee for Famine Relief, Plan } \\
\text { International, Save the Children, UNICEF, AMALIMA }\end{array}$ & $86.5 \%$ & $83 \%$ \\
\hline & $\begin{array}{l}\text { Number of lactating women of } \\
\text { children } 6-23 \text { months provided } \\
\text { with nutrition education on } \\
\text { diversified nutrient-rich foods }\end{array}$ & Idem & MoHCC, MoPSE, MoPSLSW & $100 \%$ & $88.6 \%$ \\
\hline \multirow[t]{2}{*}{$\begin{array}{l}\text { Provide enrolled children } \\
\text { with diverse nutrient- } \\
\text { dense school meals }\end{array}$} & $\begin{array}{l}\text { Number of enrolled primary } \\
\text { school learners provided with } \\
\text { diverse nutrient-dense school } \\
\text { meals }\end{array}$ & $\begin{array}{l}\text { It would be worthwhile to check if the } \\
\text { APGs can be linked to locally grown } \\
\text { school feeding programme. } \\
\text { Especially in clusters working on } \\
\text { horticulture/small grains/poultry. }\end{array}$ & $\begin{array}{l}\text { MLAWRR, Cluster Agriculture Development Services, ENSURE(WVZ),FAO, Harvest } \\
\text { Plus, Help from Germany, Hilfe zur Selbshilfe Help.Germany, MLAWRR, Plan } \\
\text { International, Practical Action, Zimbabwe Super Seeds }\end{array}$ & $83.9 \%$ & $<1 \%$ \\
\hline & $\begin{array}{l}\text { Number of enrolled ECD } \\
\text { learners provided with diverse } \\
\text { nutrient-dense school meals }\end{array}$ & Idem & $\begin{array}{l}\text { MLAWRR, Care International, Cluster Agriculture Development Services, } \\
\text { Environmental Management Agency, Farmers Association of Investment Group } \\
\text { Trust, Heifer International, ICRISAT, Methodist Development Relief Agency, } \\
\text { MLAWRR, Plan International, Welfhungerlife, AMALIMA }\end{array}$ & $100 \%$ & $100 \%$ \\
\hline $\begin{array}{l}\text { Provide seeds and other } \\
\text { planting materials for } \\
\text { biofortified crops }\end{array}$ & $\begin{array}{l}\text { Number of smallholder farming } \\
\text { households provided with seeds } \\
\text { and other planting materials for } \\
\text { biofortified crops }\end{array}$ & $\begin{array}{l}\text { See recommended pathways for SACP } \\
\text { (pre-design mission report). Investing } \\
\text { in the value chains of biofortified } \\
\text { crops can contribute to the reduction } \\
\text { of micronutrient deficiencies in } \\
\text { Zimbabwe. } \\
\text { Coverage of this action (providing } \\
\text { seeds and other planting materials for }\end{array}$ & $\begin{array}{l}\text { MLAWRR, CARITAS, Carbon Green Africa, CC, ENSURE(WVZ), Farmers Association } \\
\text { of Investment Group Trust, INSPIRE, IRCS, Lower Guruve Development Association, } \\
\text { Member of Parliament, MLAWRR, Plan International, Practical Action }\end{array}$ & & $<1 \%$ \\
\hline
\end{tabular}




\begin{tabular}{|c|c|c|c|c|c|}
\hline \multirow[t]{3}{*}{$\begin{array}{l}\text { Core nutrition actions } \\
\text { Thematic area } 2 \text { NNP }\end{array}$} & Target group & Link to SACP & Potential partners/Catalysts (field implementers in bold) & $\begin{array}{l}\text { Mbire } \\
\text { coverage }\end{array}$ & $\begin{array}{l}\text { Tsholotsho } \\
\text { coverage }\end{array}$ \\
\hline & & $\begin{array}{l}\text { biofortified crops) is generally low in } \\
\text { Zimbabwe. } \\
\text { The use of Vitamin A fortified orange } \\
\text { maize (high yielding, disease and } \\
\text { virus-resistant, drought-tolerant, } \\
\text { sweeter taste, high in carotenoids) in } \\
\text { cluster } 5 \text { is encouraged. Partnerships } \\
\text { with these catalysts can support the } \\
\text { introduction of biofortified crops } \\
\text { among small and large scale farmers. }\end{array}$ & & & \\
\hline & $\begin{array}{l}\text { Number of large scale farmers } \\
\text { provided with seeds and other } \\
\text { planting materials for } \\
\text { biofortified crops }\end{array}$ & Idem & & NA & \\
\hline $\begin{array}{l}\text { Provide inputs to } \\
\text { promote production of } \\
\text { adaptable small livestock } \\
\text { breeds with high } \\
\text { turnover }\end{array}$ & $\begin{array}{l}\text { Number of smallholder farming } \\
\text { households provided with } \\
\text { inputs to promote production of } \\
\text { adaptable small livestock } \\
\text { breeds with high turnover }\end{array}$ & $\begin{array}{l}\text { Links to cluster } 2 \text { (goats and sheep in } \\
\text { Mashona land central - Mbire), } 4 \text { (of } \\
\text { small livestock in Mashona land East), } \\
6 \text { (Poultry and piggery in } \\
\text { Mashonaland West), and } 8 \text { (Beef and } \\
\text { goats in Matabeleland North - } \\
\text { Tsholotsho). Partnerships to promote } \\
\text { nutrition education, especially on the } \\
\text { importance of household consumption } \\
\text { of animal source foods (small } \\
\text { livestock). }\end{array}$ & $\begin{array}{l}\text { AAZ, MLAWRR, Care International, Cluster Agriculture Development Services, } \\
\text { Environmental Management Agency, Farmers Association of Investment Group } \\
\text { Trust, Heifer International, ICRISAT, Methodist Development Relief Agency, } \\
\text { MLAWRR, Plan International, Welfhungerlife, AMALIMA, Practical Action }\end{array}$ & $1.4 \%$ & $1.6 \%$ \\
\hline $\begin{array}{l}\text { Provide training on good } \\
\text { agricultural practices and } \\
\text { food safety issues }\end{array}$ & $\begin{array}{l}\text { Number of extension workers } \\
\text { who are trained in good } \\
\text { agricultural practices and food } \\
\text { safety issues }\end{array}$ & $\begin{array}{l}\text { Links to pathway recommended by } \\
\text { pre-design study mission, of capacity } \\
\text { building of extension workers to be } \\
\text { able to train SMF (M/F) in concrete } \\
\text { CSA techniques and nutrition- } \\
\text { sensitive value chains and farming as } \\
\text { a business (markets, supply chain } \\
\text { logistics, access to loans, etc.) and } \\
\text { the importance of household nutrition. } \\
\text { Partnership with these catalysts could } \\
\text { support the organisation and } \\
\text { implementation of training to } \\
\text { extension workers. Adding nutrition- }\end{array}$ & $\begin{array}{l}\text { MLAWRR, CARITAS, Carbon Green Africa, Care International, Cluster for } \\
\text { agricultural development Services, Center for Development Zimbabwe, } \\
\text { ENTERPRIZE, ENSURE(WVZ), Investment Group Trust, FAO, Harvest Plus, Hilfe } \\
\text { zur Selbshilfe Help Germany, Methodist Development Relief Agency, MoHCC, } \\
\text { Mwenezi Development Training Centre, Plan International, Practical Action, WVI, } \\
\text { Zambezi Valley Alliance, AMALIMA }\end{array}$ & $100 \%$ & $100 \%$ \\
\hline
\end{tabular}




\begin{tabular}{|c|c|c|c|c|c|}
\hline \multirow[t]{3}{*}{$\begin{array}{l}\text { Core nutrition actions } \\
\text { Thematic area } 2 \text { NNP }\end{array}$} & Target group & Link to SACP & Potential partners/Catalysts (field implementers in bold) & $\begin{array}{l}\text { Mbire } \\
\text { coverage }\end{array}$ & $\begin{array}{l}\text { Tsholotsho } \\
\text { coverage }\end{array}$ \\
\hline & & $\begin{array}{l}\text { sensitive and climate agriculture to } \\
\text { the curriculum under SACP. }\end{array}$ & & & \\
\hline & $\begin{array}{l}\text { Number of small scale farmers } \\
\text { who are trained on good } \\
\text { agricultural practices and food } \\
\text { safety issues }\end{array}$ & Idem & & $25.2 \%$ & $52.5 \%$ \\
\hline $\begin{array}{l}\text { Promote district-specific } \\
\text { national food baskets in } \\
\text { every ward (seasonal } \\
\text { calendars) }\end{array}$ & $\begin{array}{l}\text { Number of wards that promote } \\
\text { district-specific national food } \\
\text { baskets }\end{array}$ & $\begin{array}{l}\text { Relevant for all districts where SACP } \\
\text { plans to integrate awareness raising } \\
\text { and education activities on healthy } \\
\text { diets and nutrition. Partner with these } \\
\text { catalysts to ensure that local foods } \\
\text { (selected for the VC interventions } \\
\text { under SACP), are included in } \\
\text { promotion material for ward-specific } \\
\text { food baskets. } \\
\text { Leafy vegetables are selected for } \\
\text { cluster } 3 \text {, in Mashonaland East. It is } \\
\text { important that smallholder farmers } \\
\text { also consume own production of these } \\
\text { leafy vegetable. }\end{array}$ & $\begin{array}{l}\text { MLAWRR, CFNA Cultivating New Frontiers In Agriculture AMALIMA,FAO, FNC, Hilfe } \\
\text { zur Selbshilfe Help.Germany, Plan International, Practical Action, AMALIMA, MoHCC }\end{array}$ & NA & $100 \%$ \\
\hline \multicolumn{6}{|l|}{$\begin{array}{l}\text { Core nutrition action } \\
\text { thematic area } 6 \text { of NNP }\end{array}$} \\
\hline $\begin{array}{l}\text { Provide information } \\
\text { package on } \\
\text { micronutrient } \\
\text { malnutrition and } \\
\text { interventions to address } \\
\text { MDD }\end{array}$ & $\begin{array}{l}\text { Number of wards provided with } \\
\text { information package on } \\
\text { micronutrient malnutrition and } \\
\text { interventions to address MDD }\end{array}$ & $\begin{array}{l}\text { Partnership for nutrition education on } \\
\text { micronutrient deficiencies and dietary } \\
\text { diversity for SMF households. }\end{array}$ & $\begin{array}{l}\text { CFNA Cultivating New Frontiers In Agriculture AMALIMA, Care International, } \\
\text { ENTERPRIZE, ENSURE(WVZ), Farmers Association Of Self Help Investment } \\
\text { Group, MoHCC, MLSW, UNICEF }\end{array}$ & $65 \%$ & $90.9 \%$ \\
\hline $\begin{array}{l}\text { Promote/utilise } \\
\text { information package on } \\
\text { biofortification targeting } \\
\text { agro-dealers }\end{array}$ & $\begin{array}{l}\text { Number of registered agro- } \\
\text { dealers who received } \\
\text { information package on bio- } \\
\text { fortification targeting agro- } \\
\text { dealers }\end{array}$ & $\begin{array}{l}\text { Strategic partners for dissemination of } \\
\text { information to agro-dealers, in case } \\
\text { biofortified crops are included in the } \\
\text { value chain interventions of SACP. }\end{array}$ & $\begin{array}{l}\text { MLAWRR, CFNA Cultivating New Frontiers In Agriculture AMALIMA, ENTERPRIZE, } \\
\text { ENSURE(WVZ), German Agro Action, MLAWRR, MoHCC, Practical Action }\end{array}$ & $20 \%$ & $27.3 \%$ \\
\hline
\end{tabular}


Wageningen Centre for Development Innovation

Wageningen University \& Research

P.O. Box 88

6700 AB Wageningen

The Netherlands

T +31 (0)317486800

www.wur.eu/cdi

Report WCDI-21-162
The mission of Wageningen University \& Research is 'To explore the potential of nature to improve the quality of life'. Under the banner Wageningen University \& Research, Wageningen University and the specialised research institutes of the Wageningen Research Foundation have joined forces in contributing to finding solutions to important questions in the domain of healthy food and living environment. With its roughly 30 branches, 6,800 employees (6,000 FTEs) and 12,900 students, Wageningen University $\&$ Research is one of the leading organisations in its domain. The unique Wageningen approach lies in its integrated approach to issues and the collaboration between different disciplines. 



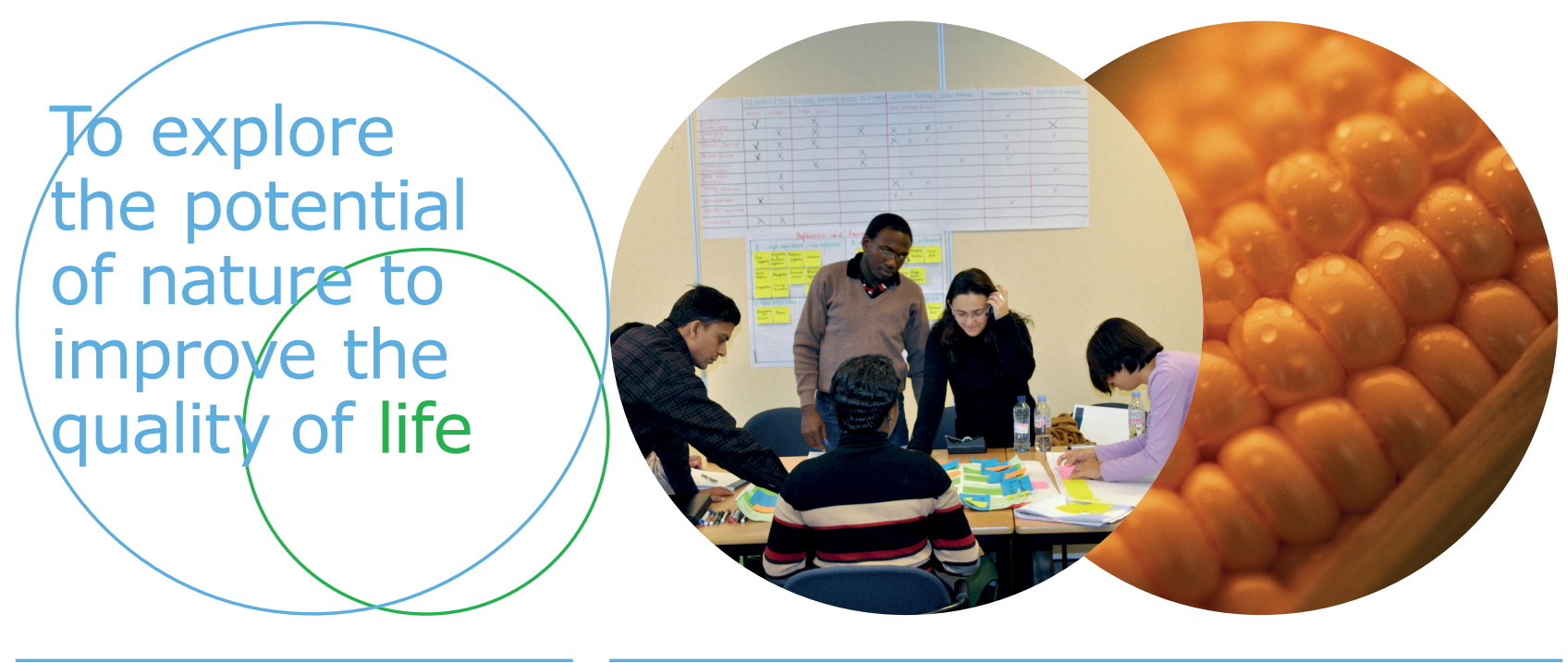

Wageningen Centre for Development Innovation Wageningen University \& Research P.O. Box 88 $6700 \mathrm{AB}$ Wageningen The Netherlands $\mathrm{T}+31$ (o)317 4868 oo www.wur.eu/cdi

Report WCDI-21-162
Wageningen Centre for Development Innovation supports value creation by strengthening capacities for sustainable development. As the international expertise and capacity building institute of Wageningen University \& Research we bring knowledge into action, with the aim to explore the potential of nature to improve the quality of life. With approximately 30 locations, 6,800 members (6,000 fte) of staff and 12,900 students, Wageningen University \& Research is a world leader in its domain. An integral way of working, and cooperation between the exact sciences and the technological and social disciplines are key to its approach. 